\title{
The Penikat Intrusion, Finland: Geochemistry, Geochronology, and Origin of Platinum- Palladium Reefs
}

\author{
W. D. Maier ${ }^{1 *}$, T. Halkoaho ${ }^{2}$, H. Huhma ${ }^{3}$, E. Hanski ${ }^{4}$ and S.-J. Barnes ${ }^{5}$ \\ ${ }^{1}$ School of Earth and Ocean Sciences, Cardiff University, Cardiff, UK; ${ }^{2}$ Geological Survey of Finland, Kuopio, \\ Finland; ${ }^{3}$ Geological Survey of Finland, Espoo, Finland; ${ }^{4}$ Oulu Mining School, Oulu, Finland; ${ }^{5}$ Université du Québec à \\ Chicoutimi, Quebec, Canada \\ *Corresponding author. E-mail: MaierW@cardiff.ac.uk \\ Received November 21, 2016; Accepted May 8, 2018
}

\begin{abstract}
The Palaeoproterozoic Penikat layered ultramafic-mafic intrusion in northern Finland is one of the most richly mineralized layered intrusions on Earth, containing at least six platinum-group element (PGE) enriched horizons exposed along $>20 \mathrm{~km}$ of strike, amongst them the SJ reef, which at 3-7 ppm Pt $+\mathrm{Pd}$ over a width of $\sim 1-2 \mathrm{~m}$ is surpassed by few other PGE reefs globally in terms of its endowment in PGE. Important PGE enrichments also occur in the PV reef (average 2.6 ppm Pd, $4 \mathrm{ppm}$ Pt over $1.1 \mathrm{~m}$ ) and AP1 reef (average $6.2 \mathrm{ppm} \mathrm{Pd}, 1.7 \mathrm{ppm}$ Pt over $0.7 \mathrm{~m}$ ). Here we present new major and high-precision trace element and $\mathrm{Nd}$ isotope data from a traverse across the intrusion, and a new $\mathrm{U}-\mathrm{Pb}$ age of $2444 \pm 8 \mathrm{Ma}$ for the intrusion. We show that the PGE reefs formed by predominantly orthomagmatic processes as, for example, reflected by well-defined positive correlations between $\mathrm{Pt}+\mathrm{Pd}$ and $\mathrm{Os}+\mathrm{Ir}+\mathrm{Ru}$ contents. Late-magmatic fluids played no significant role in concentrating PGE. There are at least six cyclic units in the intrusion, displaying a progressive upward decrease in differentiation indices $\mathrm{Mg \#}$ and $\mathrm{Cr} / \mathrm{V}$. Subdued stratigraphic variations in incompatible trace element ratios ( $\mathrm{Ce} / \mathrm{Sm}$ mostly $5-10)$ and $\mathrm{Nd}$ isotope compositions $(\varepsilon \mathrm{Nd}-3$ to -1$)$ indicate that mixing of magmas of distinct lineage, or in situ contamination with country rocks, was not required to form the PGE reefs. There is also no evidence for addition of external sulphur to the magma, based on S/Se ratios at, or below, primitive mantle levels. Instead, we propose that sulphide melt saturation at Penikat was reached in response to fractionation of a siliceous, highmagnesium basalt, and that the sulphides were concentrated through hydrodynamic phase sorting, consistent with bonanza-style PGE grades in large potholes.
\end{abstract}

Key words: platinum-group elements; chromite; Palaeoproterozoic; layered intrusion; Finland

\section{INTRODUCTION}

Layered intrusions host the bulk of global resources in platinum-group elements (PGE) that are crucial in the production of vehicle exhaust catalytic converters and many other applications in, for example, the chemical and electrical industry. However, at present only four intrusions globally are mined for PGE as the main product, namely Bushveld (South Africa), Great Dyke (Zimbabwe), Stillwater (USA) and Lac des lles (Canada). Among sub-economic intrusions, the Penikat intrusion is perhaps the most richly mineralized, yet it remains relatively little studied, with few contributions having appeared in the literature since the early 1990s, following the discovery of the mineralization in the late 1980s. In this study, we first review the geology and PGE mineralization styles of the Penikat intrusion. We then present new U-Pb zircon data to refine the age of the intrusion using in situ laser ablation inductively coupled plasma mass spectrometry analysis, and new wholerock major and trace element as well as $\mathrm{Nd}$ isotopic data to propose a new model for the origin of the PGE reefs. 


\subsection{4-2.50 Ga layered intrusions in the Fennoscandian Shield}

The northeastern part of the Fennoscandian Shield hosts more than two dozen Palaeoproterozoic layered mafic-ultramafic intrusions (Fig. 1). Uranium-lead zircon and Sm-Nd whole-rock data have yielded a mean age for the Finnish intrusions of $\sim 2440 \mathrm{Ma}$ (Huhma et al., 1990, 2018). In Russia, the ages of the intrusions span a wider range, from c. 2450 to $2500 \mathrm{Ma}$ (for a summary, see Hanski \& Melezhik, 2012), possibly reflecting two distinct mantle plume events, analogous to the 2445$2490 \mathrm{Ma}$ Matachewan and 2510 Ma Mistassini events of the Superior craton (Ernst \& Bleeker, 2010), which was probably attached to Fennoscandia at the time.

The intrusions were formed by bimodal igneous activity, resulting in mafic and felsic, plutonic and extrusive rocks in Finland and NW Russia. Magnesian basaltic to dacitic volcanic rocks are exposed in the Vetreny belt, whereas felsic volcanic rocks (Hanski, 2012) and rapakivi-type granite batholiths (Rämö \& Luukkonen, 2001) occur in the Imandra Varzuga belt and greenstone belts in northeastern Finland, closely associated with the coeval $2.44 \mathrm{Ga}$ Koillismaa and Akanvaara layered intrusions. Magmatism was triggered by plume-driven aborted break-up of the Archaean Kenorland supercontinent (Amelin et al., 1995; Hanski et al., 2001; Hanski \& Huhma, 2005) and was concentrated in linear belts tracing intracratonic rift zones (Fig. 1). In Finland and neighbouring Sweden, several intrusive belts or clusters can be distinguished (Alapieti et al., 1990; Iljina \& Hanski, 2005), including those in central Lapland (Koitelainen and Akanvaara intrusions), northwestern Lapland (Tsohkoaivi, Kelottijärvi, Kurkovare, Keukiskero), and in north-central Finland. The last is the most mineralized, comprising an $\sim 300 \mathrm{~km}$ long, west-east-trending belt named the Tornio-Näränkävaara belt (TNB), which includes Penikat, the target of this study, as well as the Tornio, Kemi, Portimo, Koillismaa and Näränkävaara intrusions. The compositions of the intrusions vary from ultramafic dominated (Tornio and Näränkävaara) to mafic-ultramafic interlayered (Kemi, Penikat, Portimo), to

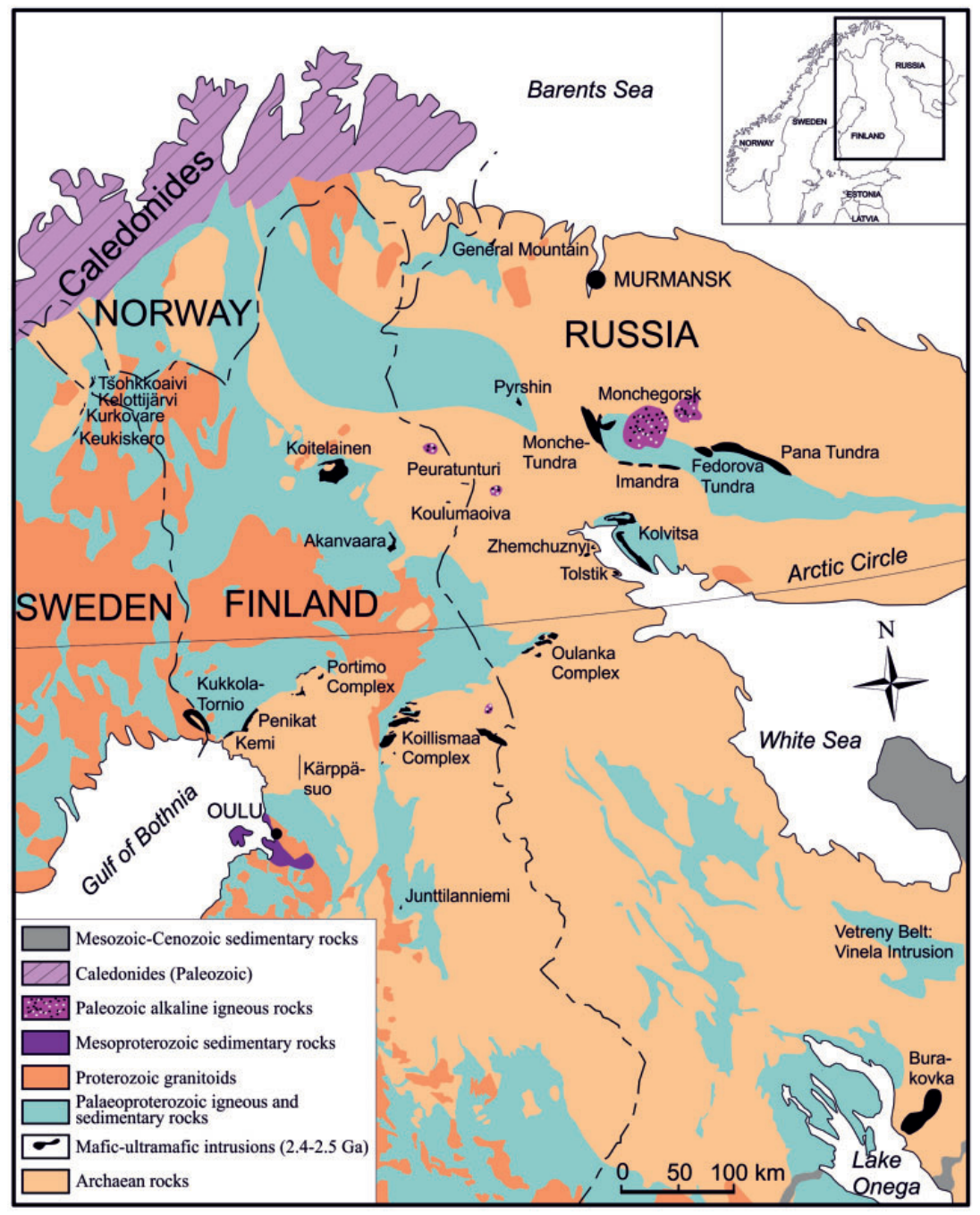

Fig. 1. Simplified geological map of part of the Fennoscandian Shield, highlighting location of 2.44-2.5 Ga layered intrusions. Figure modified after Alapieti \& Lahtinen (1989). 
predominantly mafic (Koillismaa). Based on similarities in their stratigraphy (Iljina \& Hanski, 2005; Karinen et al., 2015), some of the intrusions, or parts of them, may represent dismembered fragments of one or several larger magmatic bodies. The footwall to most of the intrusions consists of Archaean granite gneiss basement rocks, whereas the hanging-wall rocks consist of Palaeoproterozoic metavolcanic rocks or younger supracrustal sequences deposited on a Palaeoproterozoic erosional unconformity (e.g. Alapieti et al., 1989, 1990; Karinen, 2010). This may imply a relatively shallow emplacement depth followed by tilting, faulting, rapid uplift and partial erosion of the intrusions. Gravity and seismic surveys indicate that the intrusions plunge underneath the Proterozoic cover rocks for several kilometres (Kukkonen et al., 2010; Iljina \& Salmirinne, 2011).

The Finnish layered intrusions contain a wide range of PGE mineralization styles, including narrow silicatehosted reefs at Penikat and Portimo that are analogous to the Merensky Reef of the Bushveld Complex, wide contact-style reefs at Portimo and Koillismaa, analogous to the Platreef of the Bushveld, PGE-bearing chromitite layers at Kemi, Koitelainen, Akanvaara and Penikat, analogous to those in many other layered intrusions, and an unusual style of vein-hosted footwall mineralization (i.e. the Kilvenjärvi offset veins at Portimo; Andersen et al., 2006), that has rarely been identified in other layered intrusions. None of the intrusions is currently exploited for PGE, but an exploration programme in the Suhanko block of the Portimo intrusion is at an advanced feasibility stage (Puritch et al., 2007).

\section{Geology and lithostratigraphy of the Penikat intrusion}

The Penikat intrusion is a SW-NE-trending body located $\sim 20-30 \mathrm{~km}$ to the NE of Kemi, in southern Lapland (Fig. 1). Its exposed portion is $23 \mathrm{~km}$ long and $1.5-$ $3.5 \mathrm{~km}$ wide (Halkoaho, 1993). The deepest boreholes intersecting rocks of the intrusion, drilled by the Arctic Platinum Project, reach $\sim 500 \mathrm{~m}$, and the seismic reflection data of Kukkonen et al. (2010) indicate that the intrusion and its PGE reefs extend to a depth of about $2.5 \mathrm{~km}$, consistent with the gravity model of Lerssi (1990). Layering is mostly not overturned and dips 40$70^{\circ}$ to the NW, constituting what appears to be a sheetlike body. However, its SW and NE contacts are faults and thus the original size and shape of the intrusion remain unknown. Major faults also occur within the intrusion, resulting in five structurally offset blocks, named, from the north to the south, Sompujärvi, Kilkka, YliPenikka, Keski-Penikka and Ala-Penikka (Fig. 2).

The lithological variation in the Penikat intrusion is illustrated in a NW-SE-trending drillcore fence located in the Sompujärvi block (Supplementary Data Electronic Appendix 1; supplementary data are available for downloading at http://www.petrology.oxford journals.org) and in a plot of CIPW norms against height
(Fig. 3). As a whole, the intrusion is relatively mafic, with ultramafic rocks (i.e. those containing $>90 \%$ dark minerals) making up $<10 \%$ of the stratigraphy (Fig. 3). Most of the rocks are gabbronorites with about $40-60 \%$ plagioclase and $10-20 \%$ orthopyroxene and clinopyroxene each, as well as accessory $\mathrm{Cr}$-spinel, magnetite, quartz, and phlogopite. Trace phases include sulphides, K-feldspar, apatite, loveringite and others (Alapieti \& Lahtinen, 1989; Halkoaho, 1993). The paucity of ultramafic rocks constitutes a major difference from the Kemi intrusion, located immediately to the SW, which contains c. $1000 \mathrm{~m}$ of massive Iherzolite, plagioclasebearing websterite-olivine websterite and plagioclasebearing clinopyroxenite, in addition to gabbroic rocks (Alapieti et al., 1986, 1989). Further major differences from Kemi include the relatively low abundance of chromitite seams, measuring centimetres to decimetres at Penikat versus tens of metres at $\mathrm{Kemi}$, and the relative enrichment in PGE (up to tens of ppm at Penikat versus $<500$ ppb at Kemi; Linkermann, 2011). In comparison with many other layered intrusions such as Bushveld and Stillwater, anorthosites are rare at Penikat and mostly consist of thin, centimetre- to decimetre-wide bands. However, these can be traced along the entire strike of the intrusion. Massive ilmenomagnetite or apatite-rich seams are absent.

Based on CIPW norms, the intrusion has been subdivided into five megacyclic units (MCU I-V) that can be traced across most blocks, with the exception of MCU III (discontinuous in the Ala-Penikka block), and MCU V (largely absent in the Keski-Penikka and Sompujärvi blocks, probably owing to erosion) (Fig. 2). All units are characterized by relatively pyroxene-rich rocks at the base and gabbroic rocks in their upper portions (Fig. 3 and Supplementary Data Electronic Appendix 1). Olivine is absent in MCU I, but forms an important phase at the base of MCU II, III and IV, within mainly Iherzolites and olivine websterites. At the base of MCU $V$, no olivine is seen in thin section, but it is present in the CIPW norm. Olivine may also occur as a minor to major normative phase (up to $\sim 20$ normative $\%$ ) within the central to upper portions of some MCUs.

The exposed and inferred thickness of the layered series is $\sim 3000 \mathrm{~m}$. It has a sharp, magmatic basal contact with Archaean K-rich granite (Fig. 4a) locally containing abundant fluorite and galena. The contact is defined by a chilled margin at least $40 \mathrm{~cm}$ wide (Supplementary Data Electronic Appendix 2), which has a relatively evolved composition (6.5-8.0 wt \% MgO, Table 1) and is notably enriched in biotite (reflected by 4.6-5.7 wt \% $\mathrm{K}_{2} \mathrm{O}$ in the whole-rock), interpreted to be the result of in situ contamination (Halkoaho, 1993). Xenoliths of the country rocks (as e.g. in the basal portions of the Portimo and Koillismaa intrusions; Iljina, 1994; Karinen, 2010), are rarely observed, but this could simply reflect paucity of exposure.

The chilled margin is overlain by $\sim 10-20 \mathrm{~m}$ of rocks of the marginal series consisting of sub-ophitic gabbro at the base grading upwards into gabbronorite and then 


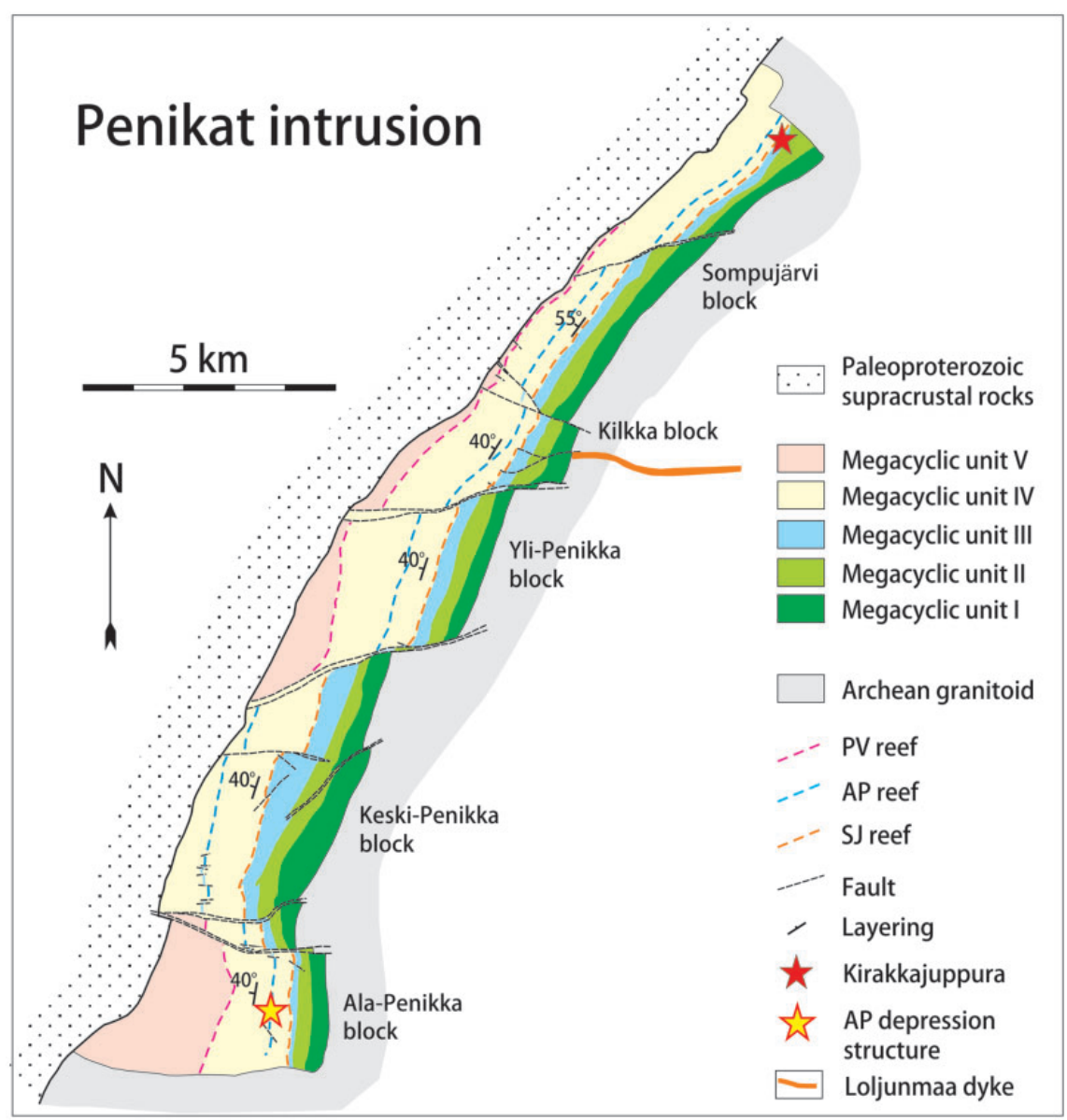

Fig. 2. Geological map of the Penikat intrusion (modified after Halkoaho et al., 2005).

plagioclase-bearing websterite, all of which may be injected by rheomorphic granite veins (Halkoaho, 1993).

The first megacyclic unit, MCU I, is between 270 and $410 \mathrm{~m}$ thick. Its base is defined by a thin (up to a few centimetres) chromite-rich zone characterized by a fine grain size of $<0.1 \mathrm{~mm}$. This is overlain by plagioclaseand chromite-bearing websterite (Fig. 4b and c; 100$350 \mathrm{~m}$ ) containing significant (up to $20 \%$ ) intercumulus plagioclase and clinopyroxene. Horizons enriched in disseminated chromite occur in the centre of the interval, and above these there is a $0.5 \mathrm{~m}$, laterally continuous, massive chromitite. The websterite contains granophyric material (Fig. 4b) as well as biotite, ilmenite, apatite and loveringite concentrated in the intercumulus space. It grades into norite, in which augite is initially mainly an intercumulus phase before attaining cumulus status in gabbronorite further up. Strong chromite disseminations can occur in the centre of the noritic-gabbronoritic interval, notably in the Sompujärvi block, whereas at the analogous stratigraphic level in the Kilkka block there are several thin anorthosite layers overlain by pegmatoids.

MCU II has a thickness of $160-230 \mathrm{~m}$ and shows more lithological variability than MCU I, particularly in its lower part where lherzolite and websterite are interlayered (Huhtelin et al., 1989b). In most parts of the intrusion the base of MCU II is formed by a websterite a few metres thick that hosts a thin (a few centimetres wide) chromitite layer near its base (see fig. 3.3 of Huhtelin et al., 1989 b). This is overlain by $20 \mathrm{~m}$ of Iherzolite (Fig. 4d) with clino- and orthopyroxene as intercumulus phases. It contains several thin layers and disseminations of chromitite. Next are $20-30$ m of websterite and then $30-70 \mathrm{~m}$ of Iherzolite containing several thin (decimetre-wide) layers of websterite. At the top of the ultramafic sequence is a sequence of alternating Iherzolite, websterite and gabbronorite, with the last being locally chromite-bearing. The upper portion of MCU II consists of gabbronorite. In the Kilkka Block this may contain four $20 \mathrm{~cm}$ wide mottled anorthosite layers (i.e. rocks consisting predominantly of cumulus plagioclase, but with abundant oikocrysts of clino- and/or orthopyroxene) near its base, whereas in the YliPenikka Block the gabbronorite contains narrow Iherzolite and websterite layers in addition to anorthosite (Huhtelin et al., 1989b). In the Yli-Penikka block there is a $100 \mathrm{~m}$ wide 'depression structure', in which MCU II transgresses through most of the gabbronoritic upper portion of MCU I. This and other depression structures at Penikat are probably analogues of the so-called 'potholes' of the Bushveld Complex. The top of MCU I is here formed by $0.5 \mathrm{~m}$ of mottled anorthosite, and the 


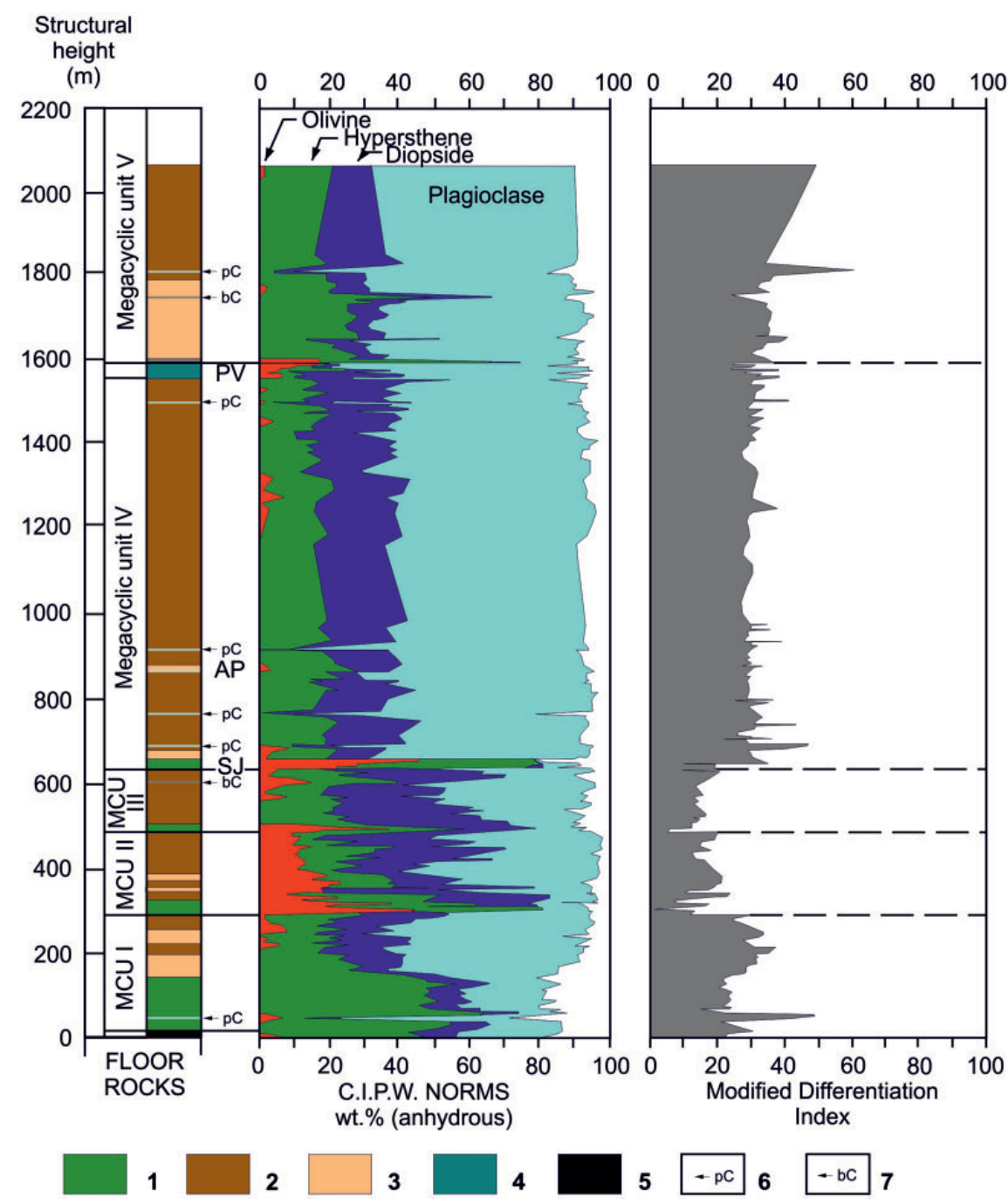

Fig. 3. Stratigraphy, CIPW norms and modified differentiation index (MDI) in a profile through the Penikat intrusion in the AlaPenikka block (modified after Alapieti \& Halkoaho, 1995). It should be noted that $>400 \mathrm{~m}$ of MCU V is preserved in this block. MDI is the sum of normative ocl $+\mathrm{ab}+\mathrm{qtz}+$ ferroan diopside + fayalite + ferrosilite, normalized to the total whole-rock norm from which the normative proportions of chromite + magnetite + ilmenite + apatite have been subtracted (von Gruenewaldt, 1973). Rock types: 1 , peridotite + pyroxenite; 2, gabbronorite (with cumulus opx and $\mathrm{cpx}$ ); 3, gabbronorite (with intercumulus augite); 4, Transition Zone; 5 , contact zone; 6 , anorthosite; 7 , bronzite cumulate layer.

potholed MCU II succession consists of a $1-2 \mathrm{~cm}$ thick chlorite schist overlain by a $0.5 \mathrm{~cm}$ undulating chromitite stringer, and then Iherzolite (Fig. $5 a$ and b). In the Ala-Penikka block, the basal ultramafic portion of MCU II is either missing or very thin.

MCU III is $75-330 \mathrm{~m}$ thick. It appears to pinch out near the exposed southern margin of the intrusion (Fig. 2). The unit consists of basal chromite-bearing websterite that measures several metres in thickness, followed by $30 \mathrm{~m}$ of chromite-bearing Iherzolite. In the middle of the latter is an $\sim 10 \mathrm{~m}$ rhythmically layered sequence in which the Iherzolite contains thin (centimetrescale) harzburgite bands (Fig. 5c). Several thin (centimetre-scale) chromitite layers occur above this zone. The Iherzolites are overlain by a few metres of websterite that may contain two thin (decimetre-scale) gabbronorite interlayers near the top. This is overlain by several tens of metres of gabbronorite, and poikilitic gabbronorite. Towards the top of the unit occur gabbronoritic pegmatoids, as well as disseminations of corroded chromite grains, with locally very high PGE contents.

MCU IV is 760-1110 $\mathrm{m}$ thick and hosts the bulk of the PGE mineralization in the form of three reefs, named, from the bottom to the top, the Sompujärvi (SJ, Fig. 5d), Ala-Penikka (AP, Fig. 6a-d) and Paasivaara (PV) reefs. The base of MCU IV hosting the SJ reef is transgressive relative to MCU III and consists of a $10-20 \mathrm{~m}$ thick ultramafic layer that can be as thin as $20-50 \mathrm{~cm}$ near the margins of the intrusion. At its base is a centimetre to $1 \mathrm{~m}$ wide basal hybrid rock or chlorite schist that can be enriched in chromite, the latter occurring as layers, schlieren, clasts and disseminations (Fig. 5e). Based on elevated $\mathrm{MgO}$ and $\mathrm{Al}_{2} \mathrm{O}_{3}$ contents, the chlorite schist 

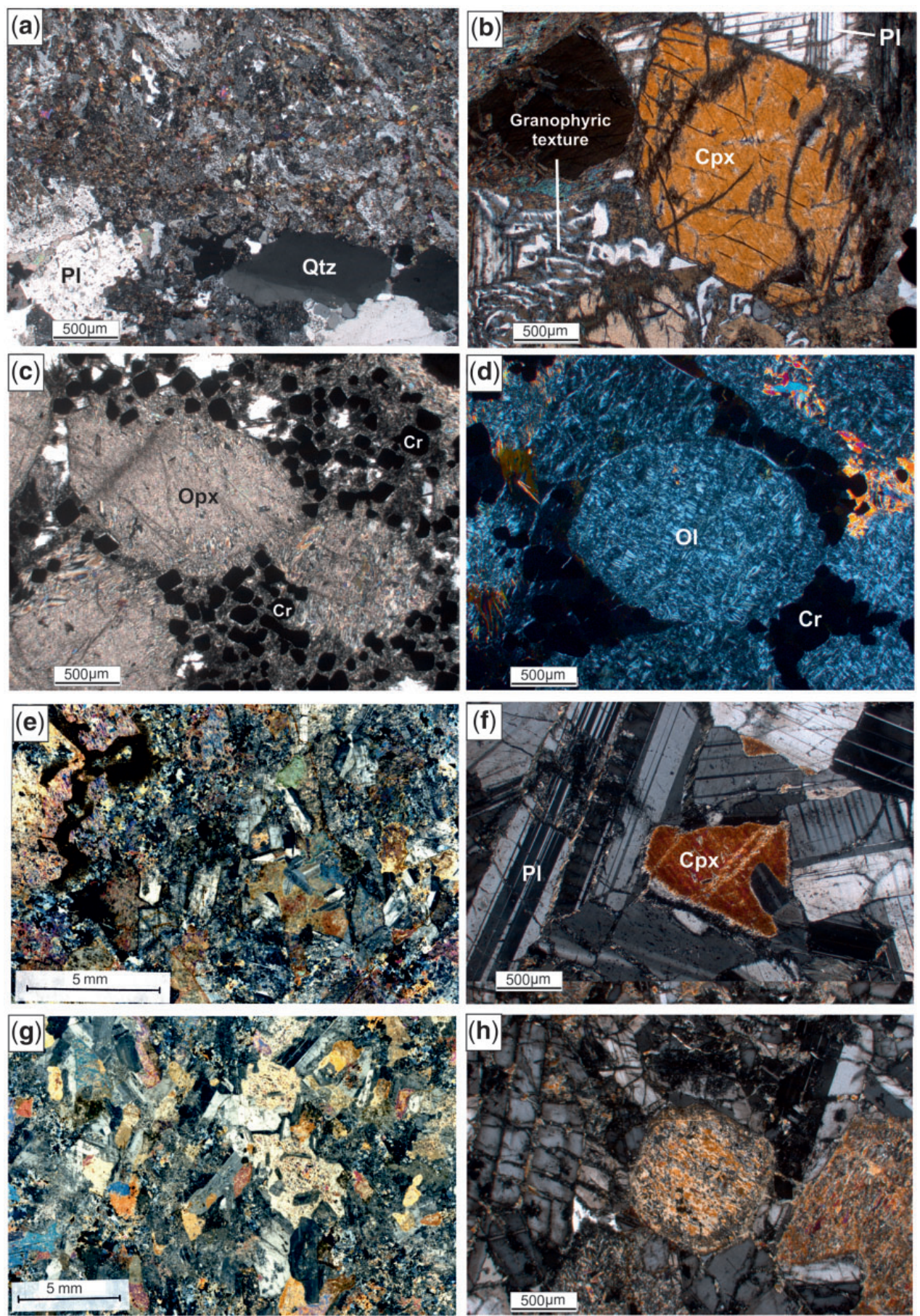

Fig. 4. Photomicrographs of Penikat rocks. (a) Basal contact of the Penikat intrusion, drillcore SiKi 6 (172 m), Lower portion of the image shows the basement and the upper portion shows the chilled margin of the intrusion. (b) Websterite orthocumulate, sample Pen 12, MCU I, 90 mab. (c) Orthopyroxenite-websterite with disseminated chromite, drillcore SiKi 6 (110.6 m, b), $\sim 60$ mab. (d) Lherzolite with interstitial chromite, drillcore SiKi 7 (252 m), MCU II, 170 mab. (e) AP1 reef gabbronorite orthocumulate with intercumulus magnetite and $5 \%$ sulphide. Silicates are strongly altered to epidote and chlorite. Sample 52A-PAT, 802.2 mab. (f) Norite in hanging wall of AP1 reef, sample Pen 30, MCU IV, 804 mab. (g) AP2 reef gabbronorite orthocumulate, strongly altered to epidote and chlorite. Rock contains 2\% sulphide. Sample 9383-7202, 891 mab. (h) Norite, sample Pen 39, MCU V, 1920 mab.

has been interpreted as a highly altered and sheared pyroxenite or melanorite (Halkoaho et al., 1989a). The chlorite schist is overlain by about $1 \mathrm{~m}$ of websterite in which clinopyroxene is an intercumulus phase, Iherzolite and then again websterite with intercumulus clinopyroxene. Next follow gabbronoritic cumulates in which orthopyroxene has a cumulus habit, whereas clinopyroxene has a poikilitic intercumulus texture; these are overlain by gabbronorite in which clinopyroxene shows a cumulus habit. In the lower portion of the 
Table 1: Composition of potential Penikat parent magmas and Bushveld parent magmas

\begin{tabular}{|c|c|c|c|c|c|c|c|c|c|c|c|c|}
\hline & \multicolumn{5}{|c|}{ 2.44 Ga Finnish dykes } & \multicolumn{4}{|c|}{$\begin{array}{l}\text { Penikat and Koitelainen } \\
\text { chilled rocks and dykes }\end{array}$} & \multicolumn{3}{|c|}{ Bushveld magmas } \\
\hline & $\begin{array}{c}\text { Bon } \\
1\end{array}$ & $\begin{array}{c}\mathrm{GN} \\
1\end{array}$ & $\begin{array}{c}\text { OPX } \\
1\end{array}$ & $\begin{array}{c}\text { Tho } \\
1\end{array}$ & $\begin{array}{c}\text { Fe-Tho } \\
1\end{array}$ & 2 & 3 & 4 & 5 & $\begin{array}{l}\text { B1 } \\
6\end{array}$ & $\begin{array}{c}\text { B2 } \\
6\end{array}$ & $\begin{array}{c}\text { B3 } \\
6\end{array}$ \\
\hline $\mathrm{SiO}_{2}$ & 53.38 & $53 \cdot 22$ & $56 \cdot 71$ & $50 \cdot 35$ & 48.56 & 51.74 & 50 & $57 \cdot 31$ & 53.69 & $55 \cdot 74$ & $50 \cdot 79$ & $51 \cdot 33$ \\
\hline $\mathrm{TiO}_{2}$ & 0.63 & 0.99 & 0.66 & 1.49 & 2.57 & 0.61 & 0.86 & 0.27 & 0.57 & 0.34 & 0.76 & 0.37 \\
\hline $\mathrm{Al}_{2} \mathrm{O}_{3}$ & $12 \cdot 32$ & $12 \cdot 81$ & 14.34 & 13.68 & 13.62 & $13 \cdot 17$ & 11.7 & 14.7 & 14.24 & 11.82 & 15.70 & $16 \cdot 14$ \\
\hline $\mathrm{Fe}_{2} \mathrm{O}_{3}$ & 11.19 & 11.77 & 9.76 & 15.03 & 15.78 & $10 \cdot 30$ & 11.80 & $10 \cdot 21$ & $10 \cdot 38$ & 10.50 & 12.54 & 10.45 \\
\hline $\mathrm{MnO}$ & 0.16 & $0 \cdot 19$ & $0 \cdot 16$ & 0.21 & 0.23 & 0.15 & $0 \cdot 16$ & 0.09 & 0.12 & 0.18 & 0.19 & 0.18 \\
\hline $\mathrm{MgO}$ & $11 \cdot 30$ & 8.52 & $5 \cdot 68$ & 6.08 & $6 \cdot 24$ & 8.40 & $11 \cdot 20$ & $6 \cdot 49$ & 8.04 & 11.85 & 6.91 & 7.69 \\
\hline $\mathrm{CaO}$ & 8.06 & 9.24 & 8.68 & $10 \cdot 18$ & 9.77 & $10 \cdot 10$ & 9.12 & 3.24 & 5.26 & 6.50 & $10 \cdot 70$ & 11.25 \\
\hline $\mathrm{Na}_{2} \mathrm{O}$ & $2 \cdot 24$ & $2 \cdot 16$ & 2.58 & $2 \cdot 27$ & $2 \cdot 16$ & $2 \cdot 80$ & 1.77 & 3.91 & $2 \cdot 76$ & 1.63 & 1.94 & 1.91 \\
\hline $\mathrm{K}_{2} \mathrm{O}$ & 0.63 & 0.98 & 1.30 & 0.58 & 0.74 & 0.72 & 0.92 & 4.57 & 5.73 & 0.98 & 0.25 & 0.28 \\
\hline $\mathrm{P}_{2} \mathrm{O}_{5}$ & 0.09 & 0.12 & 0.12 & 0.14 & 0.34 & 0.06 & 0.12 & 0.04 & 0.08 & 0.08 & 0.16 & 0.03 \\
\hline Mg\# & 0.67 & 0.59 & 0.53 & 0.44 & 0.44 & 0.62 & 0.65 & 0.56 & 0.60 & 0.69 & 0.52 & 0.59 \\
\hline $\mathrm{Ba}$ & 204 & 262 & 165 & 152 & 157 & 188 & 223 & 490 & 530 & 364 & 192 & 139 \\
\hline $\mathrm{Ce}$ & $18 \cdot 35$ & 27.71 & $43 \cdot 26$ & 26.22 & $42 \cdot 70$ & $17 \cdot 2$ & 22.7 & n.a. & n.a. & $34 \cdot 80$ & 31.74 & 11.55 \\
\hline Co & 44 & 44 & 39 & 54 & 43 & n.a. & 51 & n.a. & n.a. & 59 & 53 & 52 \\
\hline $\mathrm{Cr}$ & 962 & 488 & 72 & 122 & 259 & 466 & 992 & 470 & 440 & 965 & 201 & 408 \\
\hline Cs & 0.86 & 0.96 & 1.85 & 0.32 & 0.90 & n.a. & n.a. & n.a. & n.a. & 2.55 & 0.31 & 0.38 \\
\hline $\mathrm{Cu}$ & 67 & 83 & 73 & 184 & 387 & n.a. & 123 & n.a. & n.a. & 51 & 76 & 13 \\
\hline Dy & 1.65 & $3 \cdot 32$ & 4.02 & $5 \cdot 15$ & 6.38 & 2 & 2.57 & n.a. & n.a. & 1.90 & $3 \cdot 21$ & 1.62 \\
\hline $\mathrm{Er}$ & 0.99 & 1.92 & $2 \cdot 27$ & 3.01 & 3.81 & 1.34 & 1.6 & n.a. & n.a. & 1.05 & 1.79 & 0.96 \\
\hline Eu & 0.67 & 1.02 & 1.54 & 1.36 & 1.82 & 0.73 & 0.87 & n.a. & n.a. & 0.82 & 1.31 & 0.76 \\
\hline $\mathrm{Ga}$ & 15.01 & $17 \cdot 11$ & 18.54 & 18.96 & 17.24 & n.a. & 24 & n.a. & n.a. & 18.14 & 14.16 & 14.00 \\
\hline $\mathrm{Gd}$ & 1.70 & 3.44 & 5.05 & 4.94 & $6 \cdot 15$ & $2 \cdot 37$ & 3.07 & n.a. & n.a. & $2 \cdot 40$ & 3.61 & 1.63 \\
\hline $\mathrm{Hf}$ & 1.68 & 2.13 & 3.09 & 2.47 & 4.35 & n.a. & 1.14 & n.a. & n.a. & 1.91 & 1.33 & 0.66 \\
\hline Ho & 0.33 & 0.63 & 0.72 & 1.01 & 1.25 & 0.49 & 0.57 & n.a. & n.a. & 0.38 & 0.66 & 0.35 \\
\hline $\mathrm{La}$ & 9.05 & 13.06 & $20 \cdot 08$ & 11.53 & 18.28 & 8.63 & $10 \cdot 3$ & n.a. & n.a. & 18.00 & 14.97 & 5.66 \\
\hline Lu & $0 \cdot 19$ & 0.31 & 0.41 & 0.48 & 0.73 & 0.2 & 0.22 & n.a. & n.a. & 0.17 & 0.26 & 0.15 \\
\hline $\mathrm{Nb}$ & $2 \cdot 26$ & 5.54 & $6 \cdot 18$ & 7.40 & 12.78 & 2 & 2.85 & n.a. & n.a. & 4.15 & 3.87 & 1.42 \\
\hline $\mathrm{Nd}$ & 8.75 & $14 \cdot 17$ & 21.11 & 15.61 & 25.92 & 9.63 & 11.7 & n.a. & n.a. & 15.47 & $17 \cdot 15$ & 6.29 \\
\hline $\mathrm{Ni}$ & 308 & 152 & 60 & 71 & 131 & 104 & 354 & 90 & 104 & 284 & 106 & 133 \\
\hline $\mathrm{Pb}$ & 3.44 & 8.26 & 8.24 & 5.24 & 3.04 & n.a. & $<20$ & n.a. & n.a. & 13.92 & $4 \cdot 27$ & 2.75 \\
\hline $\operatorname{Pr}$ & 1.75 & 3.51 & $5 \cdot 36$ & $3 \cdot 20$ & 4.51 & $2 \cdot 27$ & $2 \cdot 8$ & n.a. & n.a. & 4.16 & 4.04 & 1.49 \\
\hline $\mathrm{Rb}$ & 23 & 29 & 12 & 19 & 24 & 20 & 31 & n.a. & n.a. & 40 & 4 & 9 \\
\hline S & 144 & 280 & 153 & 548 & 1965 & n.a. & 417 & 180 & 270 & 396 & 178 & 107 \\
\hline Sc & n.a. & n.a. & n.a. & n.a. & n.a. & 31 & 30 & n.a. & n.a. & 30 & $\begin{array}{l}33 \\
3.76\end{array}$ & 31 \\
\hline Sm & 2.00 & 3.52 & $4 \cdot 84$ & 4.39 & 6.69 & $2 \cdot 21$ & 2.89 & n.a. & n.a. & 2.80 & 3.76 & $\begin{array}{r}1.54 \\
337\end{array}$ \\
\hline $\mathrm{Sr}$ & 179 & 212 & 273 & 208 & 136 & 337 & 238 & 260 & 220 & 198 & 348 & 337 \\
\hline $\mathrm{Ta}$ & 0.17 & 0.33 & 0.00 & 0.69 & 0.64 & n.a. & $<0.2$ & n.a. & n.a. & 0.48 & 0.34 & 0.20 \\
\hline $\mathrm{Tb}$ & 0.30 & 0.53 & 0.82 & 0.86 & 1.20 & 0.38 & 0.47 & n.a. & n.a. & 0.34 & 0.55 & 0.26 \\
\hline Th & 1.98 & 2.67 & 4.53 & 1.70 & 1.84 & 1.3 & 2.13 & n.a. & n.a. & 3.46 & 0.68 & 0.76 \\
\hline $\mathrm{Tm}$ & 0.16 & 0.29 & 0.31 & 0.43 & 0.60 & 0.21 & 0.23 & n.a. & n.a. & 0.16 & 0.26 & 0.15 \\
\hline$U$ & 0.39 & 0.61 & 0.93 & 0.33 & 0.54 & 0.24 & 0.35 & n.a. & n.a. & 0.99 & 0.23 & 0.18 \\
\hline V & 189 & 238 & 190 & 326 & 324 & 199 & 206 & 130 & & 164 & 239 & 173 \\
\hline Y & 14.0 & 21.6 & $17 \cdot 6$ & $30 \cdot 1$ & $52 \cdot 6$ & $13 \cdot 6$ & $15 \cdot 7$ & n.a. & n.a. & 11.7 & $19 \cdot 4$ & 9.9 \\
\hline $\mathrm{Yb}$ & 1.15 & $2 \cdot 20$ & 3.19 & 3.56 & 4.58 & 1.23 & 1.59 & n.a. & n.a. & $1 \cdot 10$ & 1.73 & 0.98 \\
\hline $\mathrm{Zn}$ & 80 & 98 & 80 & 106 & 129 & 65 & 94 & 530 & & 80 & 90 & 63 \\
\hline $\mathrm{Zr}$ & 69 & 108 & 123 & 119 & 200 & 51 & 41 & 130 & 40 & 77 & 54 & 23 \\
\hline Os & 0.29 & 0.20 & n.a. & 0.13 & 0.08 & n.a. & $<1$ & n.a. & n.a. & 0.61 & 0.11 & 0.23 \\
\hline Ir & 0.54 & 0.26 & n.a. & 0.05 & 0.13 & n.a. & 0.36 & n.a. & n.a. & 0.54 & 0.21 & 0.30 \\
\hline Ru & $2 \cdot 19$ & 1.05 & n.a. & 0.07 & 0.68 & n.a. & $<2$ & n.a. & n.a. & 1.90 & 0.89 & 1.23 \\
\hline $\mathrm{Rh}$ & 1.57 & 1.12 & n.a. & 0.09 & 1.14 & n.a. & 1.58 & n.a. & n.a. & 1.78 & 0.77 & 0.74 \\
\hline $\mathrm{Pt}$ & $7 \cdot 11$ & 8.26 & n.a. & 8.14 & $12 \cdot 34$ & n.a. & 8.6 & b.d.I. & b.d.I. & 19.36 & 9.54 & 12.71 \\
\hline $\mathrm{Pd}$ & $6 \cdot 17$ & 6.48 & n.a. & 7.54 & 13.69 & n.a. & 6.27 & 14 & 12 & 13.99 & $5 \cdot 41$ & 3.85 \\
\hline $\mathrm{Au}$ & 0.88 & 0.85 & n.a. & 1.97 & 2.26 & n.a. & 1.57 & n.a. & n.a. & 2.72 & 1.90 & 0.89 \\
\hline
\end{tabular}

Bon, boninite; GN, gabbronorite; OPX, orthopyroxenite; Tho, tholeiite; Fe-Tho, Fe-tholeiite. 1, F. Guo (unpublished data); 2 , Koitelainen chilled margin (from Iljina \& Hanski, 2005); 3, Loljunmaa dyke (sample 1-LOL-2009); 4, Penikat chilled margin, sample Ki6 171.82 (from Halkoaho, 1993); 5, Penikat chilled margin, sample Ki 171.49 (from Halkoaho, 1993); 6, Barnes et al. (2010). n.a., not analysed; b.d.I., below detection limit.

gabbronorite, $\sim 100 \mathrm{~m}$ above the base of MCU IV, pronounced rhythmic layering is seen, including a thin (up to a few centimetres) anorthosite layer with sharp contacts (Fig. $5 \mathrm{~g}$ ), locally with elevated PGE contents of up to $1 \mathrm{ppm}$. Above the anorthosite is about $1 \mathrm{~m}$ of websterite and about $20 \mathrm{~m}$ above this occurs a mottled anorthosite marker horizon that defines the boundary between zones 1 and 2 of MCU IV (Fig. 5f). Some $250 \mathrm{~m}$ above the base of MCU IV is a thin $(2-10 \mathrm{~cm})$, but laterally continuous mottled anorthosite layer that has sharp but undulating contacts to its hanging-wall and footwall gabbronoritic host rocks (Fig. 6a). A further, very similar 

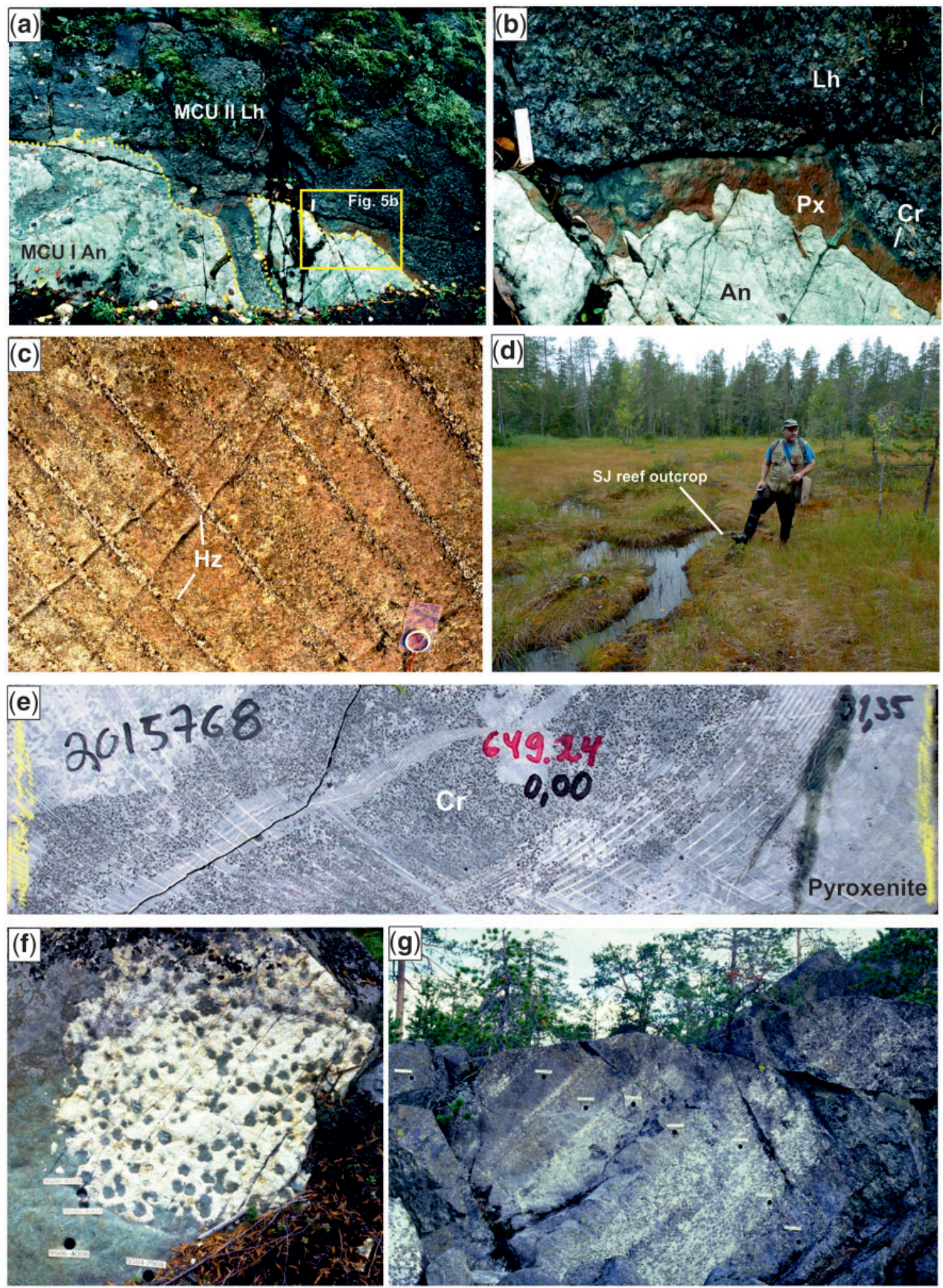

Fig. 5. (a, b) Contact between MCU I and MCU II at depression structure in Yli-Penikka block. Dip of layering is $\sim 40^{\circ}$ towards the viewer, whereas the exposure is inclined at a slightly steeper angle. At the top of MCU I is an anorthositic plagioclase orthocumulate layer (white). At the base of the overlying olivine mesocumulate (with poikilitic opx and cpx) of MCU II (dark green) is a narrow $(1-2 \mathrm{~cm}$ ) layer of metapyroxenite (now chlorite schist; brown and green), which is overlain by a chromitite (black) layer $0.5 \mathrm{~cm}$ in thickness. Ultramafic transgressive channel within anorthosite in lower portion of (a), in which Iherzolite is bracketed by chromitite and chlorite schist, should be noted. Length of the white scale is about $6.5 \mathrm{~cm}$. (c) Layering in the ultramafic sequence of MCU III, consisting of alternating layers of bronzite-bearing and bronzite-free Iherzolite, Penikanjänkä, Keski-Penikka block. Length of the compass is $12 \mathrm{~cm}$. (d) Outcrop of the MCU IV Iherzolite layer (the host-rock of the SJ Reef), Ala-Penikka block. (e) Chromitite type of the SJ Reef exposed in drillcore Pen-475, Sompujärvi block. The diffuse $\mathrm{Cr}$ stringer is $\sim 5 \mathrm{~cm}$ wide. It should be noted that sample contains $650 \mathrm{ppm}$ PGE. (f) Near-plan view of anorthosite layer (poikilitic plagioclase adcumulate, with clinopyroxene oikocrysts) $\sim 80 \mathrm{~m}$ above base of MCU IV, Ala-Penikka block. The anorthosite and the overlying $1 \mathrm{~m}$ thick websterite layer (poikilitic bronzite mesocumulate) form a prominent marker horizon throughout the Penikat Intrusion. Length of the white scales is $10 \mathrm{~cm}$. $(\mathrm{g})$ Anorthosite (poikilitic plagioclase mesocumulate) layers at the contact between zones 1 and 2 of MCI IV, Ala-Penikka Block ( 100 m above base of MCU IV). This interval forms the most prominent marker horizon in the Penikat intrusion and can be traced along the entire strike length. Length of the white scales is $10 \mathrm{~cm}$. 

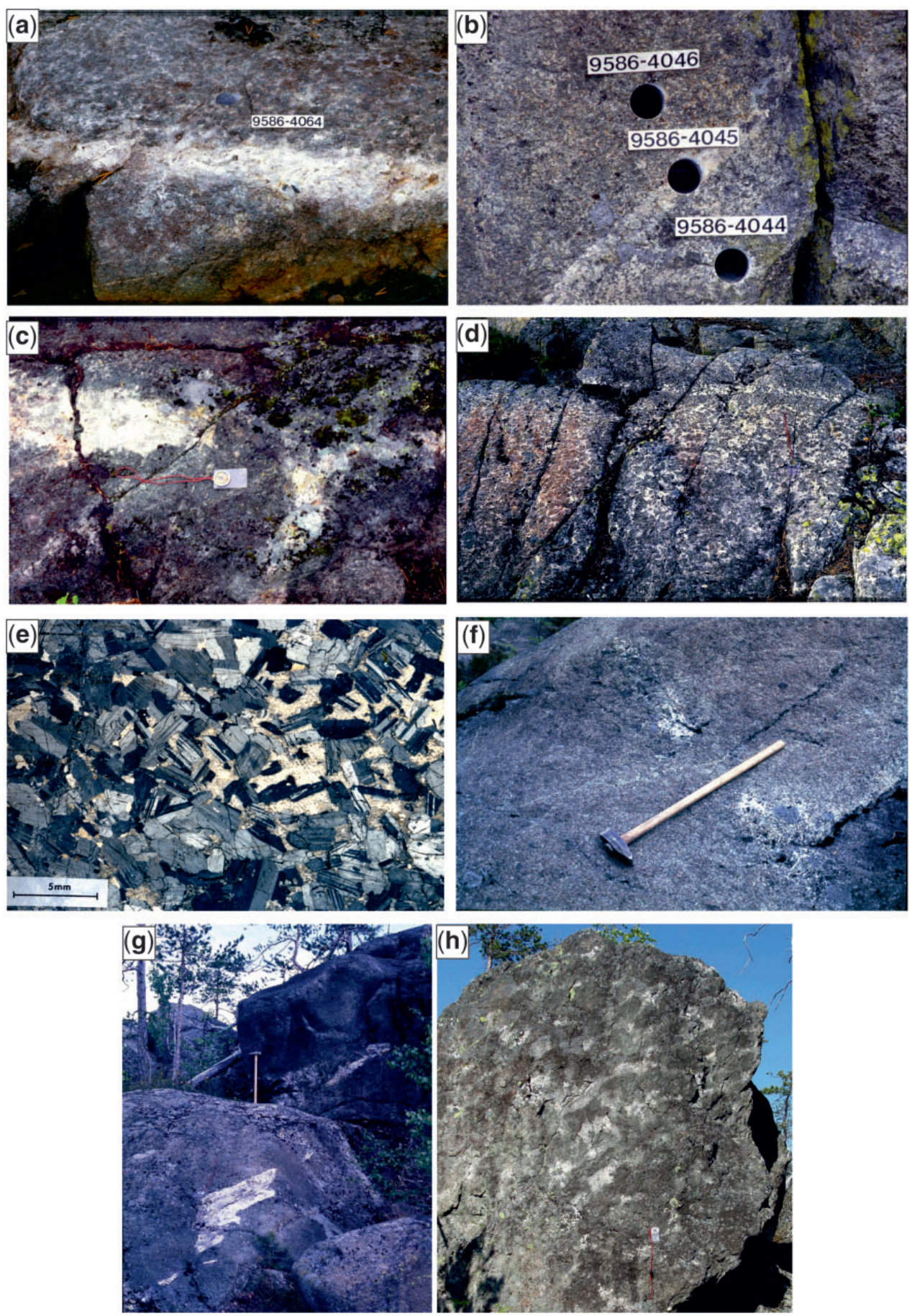

Fig. 6. (a) AP1 Reef poikilitic anorthosite with intercumulus augite, bronzite and accessory sulphides. Below the anorthosite is a plagioclase-augite-bronzite adcumulate with accessory sulphides and intercumulus ilmenomagnetite and above is a spotted plagioclase-bronzite mesocumulate with poikilitic intercumulus augite. Ala-Penikka block, $\sim 250 \mathrm{~m}$ above base of MCU IV. Length of the white scale is $10 \mathrm{~cm}$. (b) The AP2 Reef is closely associated with a thin $(2-3 \mathrm{~cm}$ ) anorthosite (poikilitic plagioclase adcumulate). The anorthosite is hosted by gabbronorite (plagioclase-augite-bronzite adcumulates). Ala-Penikka block, $\sim 345 \mathrm{~m}$ above base of MCU IV. Length of the white scales is $10 \mathrm{~cm}$. (c) Slumped AP1 reef anorthosite, Length of compass is $12 \mathrm{~cm}$. (d) Poikilitic gabbronorite mesocumulate forming thick 'mottled anorthosite' in centre of AP1 pothole. Height of exposure is 1.5m. (e) Photomicrograph of 'mottled anorthosite' in (d). (f) Pegmatoidal pods located above AP1 pothole, $\sim 20 \mathrm{~m}$ below AP2 reef. (g) Mottled anorthositic (plagioclase orthocumulate) fragments located about $180 \mathrm{~m}$ above the base of the AP1 depression structure, $\sim 300 \mathrm{~m}$ above base of MCU IV, Ala-Penikka block. Length of the hammer is $65 \mathrm{~cm}$. (h) Mixed rock of the Transition Zone (PV reef) in the upper part of MCU IV ( 980 m above base of MCU IV) The mixed rock is composed of white patches of plagioclase adcumulate and darker patches of plagioclase and/or plagioclase-bronzite cumulate in which intercumulus augite occurs as oikocrysts. 
thin anorthosite occurs another $100 \mathrm{~m}$ up-section (Fig. 6b). The anorthosite layers and their immediate footwall rocks host the AP1 and AP2 PGE reefs (Halkoaho, 1989, 1993; Halkoaho et al., 1990 b). The reefs are strongly altered relative to their hanging-wall rocks. The AP1 anorthosite can locally be disrupted and may slump into its footwall (Fig. 6c). In places, the AP1 anorthosite and its hanging-wall norite are transgressive relative to their footwall, forming a large pothole, somewhat analogous to the large anorthosite potholes in the Bushveld Complex (Maier et al., 2016). Within the pothole, the anorthosite is markedly thickened, and the pyroxene oikocrysts appear to have become larger and more abundant, essentially resulting in a poikilitic gabbronorite (Fig. 6d,e). Numerous pegmatoidal pods are also developed (Fig. 6f).

Decimetre-sized anorthosite fragments (Fig. 6g) commonly occur between the two AP reefs, notably above the main AP1 depression structure. Approximately $900 \mathrm{~m}$ above the base of MCU IV is a further mottled anorthosite layer, and $100 \mathrm{~m}$ above this, at the top of MCU $\mathrm{IV}$, is a $40-60 \mathrm{~m}$ thick, highly complex zone termed the Transition Zone (Huhtelin, 1989; Huhtelin et al., 1989a, 1990; Halkoaho et al., 2005). This consists of layers and lenses of gabbronorite, norite, mottled anorthosite, pegmatoid, and a 10-15 m thick 'mixed rock' composed of irregular, up to $0.5 \mathrm{~m}$ wide patches or fragments of poikilitic gabbro and 1-2 $\mathrm{m}$ sized autoliths of gabbronorite in anorthosite adcumulate (Fig. 6h). This mixed rock layer has a thin anorthosite layer at its base, and both can be transgressive to the gabbroic floor rocks (fig. 21 of Halkoaho et al., 2005). It has been compared with the Mixed Rock of the J-M reef of the Stillwater Complex (Turner et al., 1985) and possibly represents a magmatic breccia of anorthosite and gabbronorite (Huhtelin et al., 1990). This zone hosts the PV reef, which is described in more detail below.

MCU $V$ has a highly variable thickness. The unit is up to $900 \mathrm{~m}$ thick in the Ala-Penikka block, but entirely absent in the Keski-Penikka and most of the Sompujärvi blocks, probably owing to erosion. At the base of the unit is $4-10 \mathrm{~m}$ of websterite (with intercumulus clinopyroxene) displaying a basal contact that undulates relative to the underlying Transition Zone on a scale of metres. The websterite grades upwards into norite. Towards the top of MCU V occur norite (Fig. 4h), gabbronorite, gabbro, leucogabbro, anorthosite, and plagioclasequartz-biotite rocks containing minor ilmenomagnetite throughout. The uppermost exposed rocks resemble the granophyre in the roof of the Koillismaa intrusion (Iljina \& Hanski, 2005). Based on geophysical data, these lithologies are overlain by at least a further $500 \mathrm{~m}$ of intrusive rocks under cover.

\section{MINERALOGY AND MINERAL CHEMISTRY}

The petrography and mineral chemistry of the intrusion have been studied in detail by Halkoaho $(1989,1993)$, Halkoaho et al. (1989a, 1989b, 1990a, 1990b) and
Alapieti \& Halkoaho (1995), and only a brief summary of the data is given here. Prior to pervasive greenschist- to amphibolite-facies alteration to pseudomorphs of serpentine, amphibole and carbonate, olivine formed euhedral or subhedral grains of up to several millimetres in diameter. Owing to its alteration (Fig. 4d) its primary composition could generally not be determined.

Orthopyroxene occurs throughout the intrusion and tends to be strongly uralitized (Fig. 4c, e and g), but some unaltered grains of euhedral and subhedral habit could be analysed in most units, ranging in composition from En 80.9 to 67.3 , and containing up to 0.56 wt $\% \mathrm{Cr}_{2} \mathrm{O}_{3}$. Clinopyroxene is also present throughout the intrusion and could be analysed in most units. It has an intercumulus habit in most ultramafic rocks, notably in MCU I, II, IV and $\mathrm{V}$, and in the basal parts of the mafic portions of all megacyclic units, but attains cumulus status towards the top of most megacyclic units. Clinopyroxene is less altered than orthopyroxene, thus its composition has been particularly useful in constraining the compositional cyclicity of the intrusion (Halkoaho, 1993; Alapieti \& Halkoaho, 1995). In MCU I, II and III, the data show normal differentiation trends of decreasing Mg\# with height, with sharp reversals towards elevated $\mathrm{Mg \#}$ at the base of units. The most primitive grains occur in MCU II, where $\mathrm{Mg} \#$ reaches $90 \%$, with up to $1.3 \mathrm{wt} \% \mathrm{Cr}_{2} \mathrm{O}_{3}$. One of the most notable features evident in the clinopyroxene data is the markedly lower Mg\# and $\mathrm{Cr}$ content in clinopyroxenes of MCU IV, relative to the under- and overlying units. This pattern has led a number of researchers to propose two distinct magmatic lineages for the intrusion, one being relatively $\mathrm{Cr}$-rich and the other $\mathrm{Cr}$-poor (Halkoaho, 1993; Alapieti \& Halkoaho, 1995), as discussed in more detail below.

Plagioclase is the least altered of the major silicates and is present throughout the intrusion. Its composition ranges from An 60 to $82 \%$, with the highest values observed in norites and gabbronorites of MCU II and III. The anorthite contents of intercumulus plagioclase in the ultramafic rocks can be as low as 55\%.

Cumulus chromite occurs in most rocks of MCU I and II, and in the peridotites and pyroxenites of MCU III, IV and V. The grain size of the chromite shows a broadly progressive coarsening with height. In the peridotites and pyroxenites, euhedral and subhedral grains are mostly confined to the intercumulus domains between cumulus olivine and orthopyroxene (Fig. 4c and d), whereas chromite grains at the base of, and below, MCU IV typically are strongly annealed, analogous to those in the Merensky Reef of the Bushveld Complex (Eales \& Reynolds, 1986), and may form inclusions within augite. Chromite has relatively constant $\mathrm{Cr}_{2} \mathrm{O}_{3}$ contents in the peridotites, pyroxenites and norites, with a maximum of just over $40 \mathrm{wt} \%$.

Cumulus ilmenite and magnetite are relatively minor phases, but may occur in MCU IV and V, with ilmenite being more abundant.

Apatite is a trace phase throughout the intrusion, but may be common in MCU I and V. The grains can reach 
up to $1 \mathrm{~mm}$ in length and are mostly of intercumulus habit, except in the upper parts of MCU IV and V. Halkoaho (1993) studied apatite compositions in four blocks of the Penikat intrusion and showed that F contents generally increase with height, but show a particularly pronounced increase across the MCU III-IV boundary. $\mathrm{Cl}$ contents tend to be highest near the base of the intrusion, but in the Ala-Penika block, there is an additional strong increase in $\mathrm{Cl}$ (in excess of $2 \%$ ) in the lower portions of MCU IV and MCU V.

Sulphides are trace phases throughout much of the intrusion, comprising mainly pyrrhotite, chalcopyrite, and pentlandite. Elevated pyrite contents, as well as trace bornite, sphalerite, galena, millerite and violarite, are found in some of the reefs. The SJ and AP reefs contain abundant platinum-group minerals (PGM) (Halkoaho, 1993), with diameters between 1 and $300 \mu \mathrm{m}$. These are described in more detail below.

\section{DESCRIPTION OF PGE-ENRICHED ZONES}

\section{Chromitites in MCU I-IV}

Chromitite seams occur throughout the lower portion of the Penikat intrusion. The seams are mostly relatively thin $(<10 \mathrm{~cm})$, except for one $0.5-0.8 \mathrm{~m}$ wide seam within MCU I. The lateral continuity of most chromitites is not well established, owing to poor exposure and the low number of drillcore intersections in the basal portion of the intrusion, mainly confined to the Sompujärvi block (Supplementary Data Electronic Appendix 1). Chromitite seams, stringers or disseminations occur within websterite or Iherzolite at the base of cyclic units (MCU I, II, IV) or within norite or gabbronorite in the centre and towards the top of units (MCU I, II, III). The

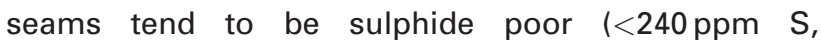
$<130 \mathrm{ppm} \mathrm{Cu}$, Huhtelin et al., 1989b). They show a broad trend of increasing grain size, PGE contents and PGE fractionation with height; seams in MCU II contain $<300 \mathrm{ppb} P G E$, with $\mathrm{Pt} / \mathrm{Pd} \sim 1$ and $\mathrm{Pd} / \mathrm{lr}$ 4-5, whereas seams in MCU III have up to $3 \mathrm{ppm}$ total PGE, with $\mathrm{Pt} / \mathrm{Pd}$ $>2$ and $\mathrm{Pd} / \mathrm{Ir}$ up to 10 (Huhtelin et al., 1989b).

\section{The SJ (Sompujärvi) reef}

The SJ reef is a classical PGE reef sharing many similarities with, for example, the Merensky Reef of the Bushveld Complex: in both cases a relatively narrow zone of PGE-rich sulphide mineralization (thickness typically $\sim 1 \mathrm{~m}$ ) is closely associated with one, or in the case of Bushveld, several chromitite stringers, predominantly along, or near the lower contact of an ultramafic layer that forms the base of a cyclic unit. The ultramafic and mafic rocks below and above the reefs are mostly strongly PGE depleted.

The detailed stratigraphy of the SJ reef interval is highly complex, with several distinct PGE mineralization styles being described by Halkoaho et al. (1989a, 1990a) and Halkoaho (1993) (Supplementary Data Electronic Appendix 3). The mineralization is concentrated within the lowermost ultramafic rocks of MCU IV, typically consisting of a centimetre to metre thick chlorite schist, which is commonly enriched in chromite occurring as disseminations or stringers and schlieren. Above the chlorite schist can sometimes occur an orthopyroxenite or olivine orthopyroxenite layer, typically up to $1 \mathrm{~m}$ in thickness, but locally reaching $3 \mathrm{~m}$ in thickness. More usually, the chlorite schist is overlain by a thick (10-20 m) Iherzolite. In places, mineralization can extend, in patchy form, for several decimetres or metres into the gabbronoritic footwall, where it can be associated with chromite disseminations and pyroxenite lenses and layers (Fig. 7).

A typical profile across the reef is shown in Fig. 7c. Of note is that the increase in $\mathrm{MgO}$ and decrease in $\mathrm{Al}_{2} \mathrm{O}_{3}$, reflecting the appearance of ultramafic rocks, is accompanied by sharply lower $\mathrm{Mg \#}$ and $\mathrm{Cr}$ contents in the whole-rocks and augite than in the footwall gabbronorites, suggesting that the sulphides of the reef precipitated from relatively evolved magma.

The MCU IV ultramafic rocks are laterally of variable thickness, and they may pinch out and form channels or so-called 'depression structures' that are transgressive relative to the footwall layers. They probably are analogues to the potholes of the Bushveld Complex (Maier et al., 2016, and references therein). The depression structures in the SJ reef tend to be enriched in disseminated chromite (e.g. at Kirakkajuppura) and can be extensive. For example, in the northern part of the Sompujärvi block, MCU III is just $30 \mathrm{~m}$ thick, suggesting several tens of metres of magmatic erosion. At the northern and southern edges of the intrusion the ultramafic portion of MCU IV can be very thin and may pinch out altogether. It remains unclear whether these are large-scale erosional structures or reflect a distal facies of the intrusion relative to a feeder zone (see Eales et al., 1988).

Halkoaho (1993) distinguished four types of PGE mineralization in the SJ reef. (1) In the sulphide-dominated type the PGE are associated with sulphide enrichments of up to several per cent (Supplementary Data Electronic Appendix 3). This type of mineralization tends to be located in the basal chlorite schist or websterite of MCU IV and sometimes in the overlying lherzolite. The peak sulphide abundance tends to occur near the base of the Iherzolite, whereas the peak PGE values are usually in the underlying websterite and schist. (2) In the chromite type, sulphides are rare (usually $<0.1$ modal $\%$ ), but PGE are closely associated with disseminations of up to $\sim 10$ modal $\%$ chromite (Supplementary Data Electronic Appendix 4) in MCU IV websterite, chlorite schist or their gabbronoritic footwall. This type has markedly higher PGE grade than the other types. (3) The silicate type can occur in all rock types. PGE occur as PGM within silicates, whereas sulphides and chromite are sparse $(<0.1 \%)$, to the effect that the mineralization is macroscopically invisible (Supplementary Data Electronic Appendix 5). (4) In the composite type, PGE enrichments occur in 

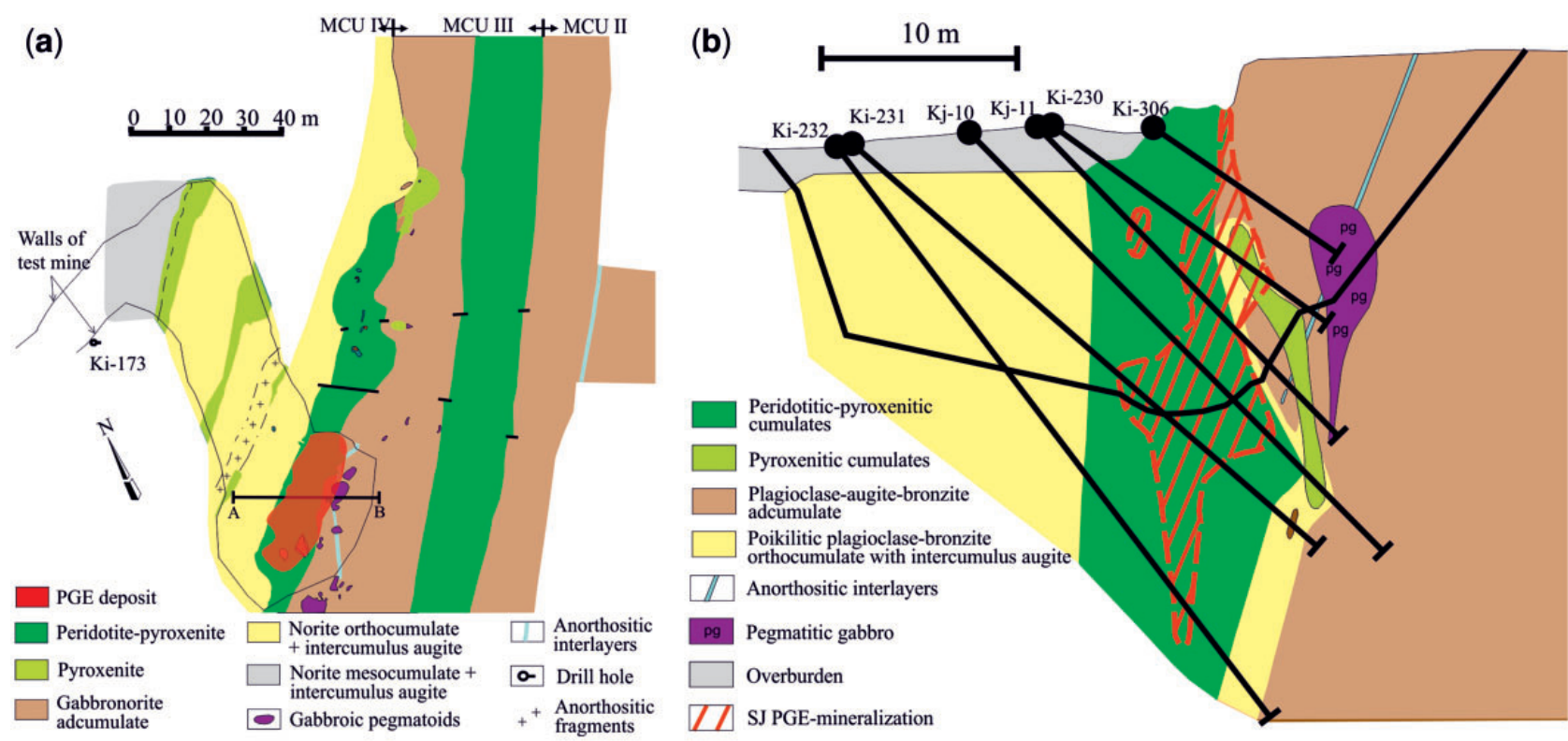

(c)

\section{Ki 165}
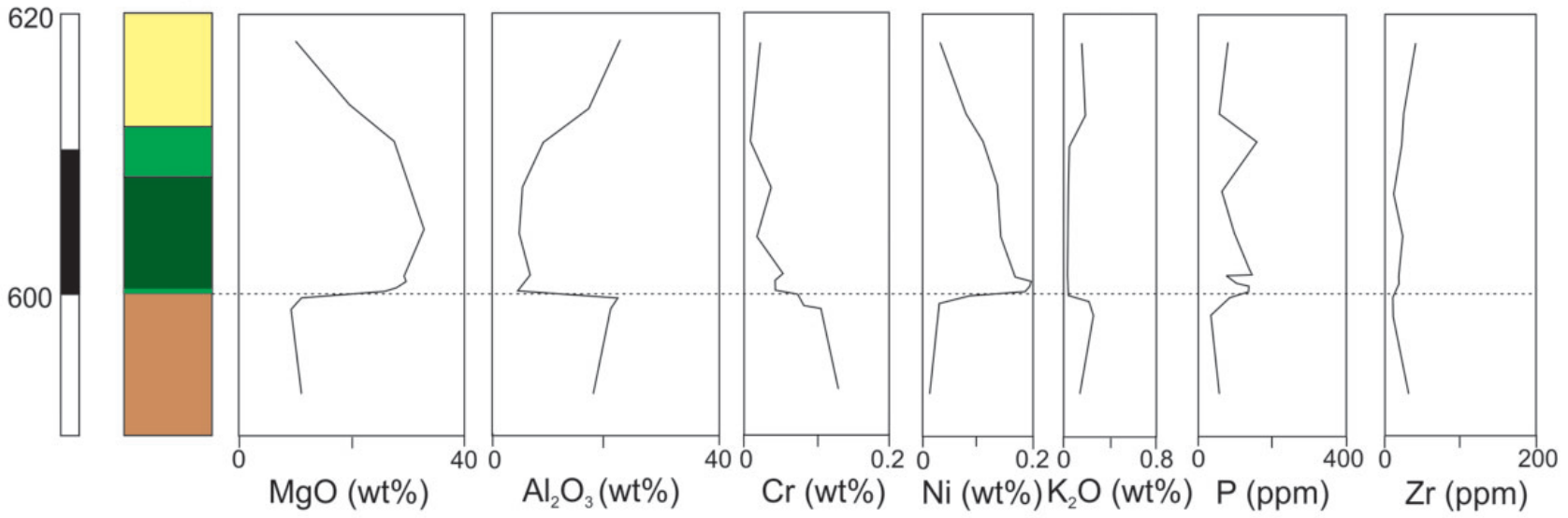

Pyroxenite $\square$ Ol-pyroxenite

Norite

Gabbronorite

Fig. 7. (a) Outcrop map of the SJ reef sequence at Kirakkajuppura, Sompujärvi block. The poor lateral continuity and irregular basal contact of ultramafic rock at base of MCU IV, contrasting with planar contacts of the MCU III ultramafic layer, should be noted. Also noteworthy is the pod-like nature of the PGE deposit, and abundance of pegmatoidal patches below the SJ reef. Outline of test pit is shown by black continuous line. Modified after Halkoaho et al. (2005). (b) Cross-section through the SJ reef at Kirakkajuppura where the reef is locally thickened. Potholing and the irregular nature of the SJ reef should be noted. Modified after Halkoaho et al. (2005). (c) Compositional variation across the SJ reef intersected by drillcore SiKi 165 (modified from Halkoaho et al., 1990a). The sharp decrease in $\mathrm{Cr}$ content, and lack of enrichment in incompatible elements, should be noted. (See text for further discussion.)

sulphide + chromite-enriched intervals, as well as in zones enriched in either chromite or sulphide (Supplementary Data Electronic Appendix 6). In all reef types, the rocks are strongly altered, rendering recognition of primary textures near impossible.

PGE grades are locally extremely variable, and spectacular grades of $>100 \mathrm{ppm}$ PGE over several decimetres are not uncommon (Supplementary Data Electronic Appendices 4 and 7). The highest grade recorded is from drillcore SiKi 308 at a depth interval of $4.57-4.75 \mathrm{~m}(18 \mathrm{~cm})$ in the Kirakkajuppura area, northern Sompujärvi block (Fig. 2), where concentrations of $501 \mathrm{ppm} \mathrm{Pt}, 1350 \mathrm{ppm} \mathrm{Pd}$, 58.2 ppm Rh, and $12 \mathrm{ppm} \mathrm{Au}$ are found in the uppermost gabbronorite of MCU III, peridotite of MCU IV and, in particular, a tremolitechlorite rock between the gabbronorite and peridotite. In the drillcore, the average grade over a height of $11.2 \mathrm{~m}$ is $46.4 \mathrm{ppm} \mathrm{Pd}$ and $18 \mathrm{ppm}$ Pt (i.e. $\sim 520 \mathrm{ppm} \mathrm{Pd}$ and $\sim 200 \mathrm{ppm}$ Pt normalized to a thickness of $1 \mathrm{~m}$, about 100 times that of a typical Merensky Reef intersection). However, notwithstanding the local-scale variation in grade, mineralization style and stratigraphic setting, on a larger scale the grade of the mineralization is remarkably consistent. Our compilation of the available drillcore data until 1990 indicates that of 400 holes drilled through the SJ reef along the strike of the intrusion, only $20(5 \%)$ were 'unmineralized' (i.e. contained less than $\sim 100 \mathrm{ppb} P \mathrm{PGE}$, the analytical detection limit at 
the time). The SJ reef has the following average grades in the individual blocks of the intrusion: Ala-Penikka (3.06 ppm over $1.38 \mathrm{~m}, 13$ holes), Keski-Penikka (4.54 ppm over $1.28 \mathrm{~m}, 35$ holes), Yli-Penikka $(5.96 \mathrm{ppm}$ over $1.78 \mathrm{~m}, 22$ holes), Kilkka (4.82 ppm over $1.09 \mathrm{~m}, 32$ holes), Sompujärvi North excluding Kirakkajuppura (5.84 ppm over $1.31 \mathrm{~m}, 113$ holes), and Sompujärvi South $(7.28 \mathrm{ppm}$ over $1.36 \mathrm{~m}, 185$ holes). Because drilling density is highly heterogeneous between blocks, the calculated average grades for some of the blocks are probably approximate. As mentioned above, highly enriched grades occur at Kirakkajuppura at the northern edge of the Sompujärvi block, and the bulk grade of this $115000 \mathrm{t}$ ore body is $11.3 \mathrm{ppm} \mathrm{Pt}, 19.8 \mathrm{ppm} \mathrm{Pd}$, $1.42 \mathrm{ppm} \mathrm{Rh}$ and $0.15 \mathrm{ppm}$ Au over an average reef thickness of $2.4 \mathrm{~m}$. The data further indicate that chromite-hosted mineralization dominates at Kilkka and Sompujärvi (25-35\% of all intersections), whereas this type of mineralization is nearly absent at Ala-Penikka, Keski-Penikka and Yli-Penikka, where sulphide-hosted and composite mineralization dominates $(30-68 \%$ of all intersections). The published mineral resource (to a depth of $100 \mathrm{~m}$ ) for the entire Sompujärvi block stands at $6.7 \mathrm{Mt}$ at a grade of $5.36 \mathrm{ppm} \mathrm{Pd}$ and $3.08 \mathrm{ppm}$ Pt over $0.97 \mathrm{~m}$ (Eerola et al., 1990). For the sulphide type of the $\mathrm{SJ}$ reef (across the entire Penikat intrusion), $\mathrm{Pt}$ and $\mathrm{Pd}$ contents are $2.7 \mathrm{ppm}$ each (Pt/Pd is close to unity) and $\mathrm{Pd} / \mathrm{lr}$ is 27 (Halkoaho et al., 2005). Average sulphur contents of the sulphide-type reef are $0.13 \mathrm{wt} \%$ and for the chromite-type reef $0.03 \mathrm{wt} \%$ (Halkoaho et al., 2005). The tenors of the sulphides are thus extremely high ( $1500 \mathrm{ppm} \mathrm{Pt}+\mathrm{Pd}$ in sulphide-type).

The PGM in the chromite-type of the SJ reef comprise predominantly $\mathrm{Pd}-\mathrm{As}-\mathrm{Sb}$ minerals $(49 \%$ of all grains), sperrylite $(12.7 \%)$, PGE-Fe-Cu-Mn hydroxides (9\%), PGE sulphides (except laurite, 9\%), PGE alloys (7.3\%), Sn and/or Pb-bearing PGM (3.6\%, particularly at Kirakkajuppura), laurite $(1.8 \%)$ and $\mathrm{Pd}-\mathrm{Te}-(\mathrm{Bi})$ minerals (1.8\%) (Halkoaho, 1993). Most of the PGMs occur in association with silicates, and a small amount on the edge of chromite or magnetite. Only laurite has been encountered as inclusions in chromite. In the Kirakkajuppura area, PGE sulphides dominate, whereas in the base metal sulphide type of the SJ reef, sperrylite is dominant $(31 \%)$, followed by $\mathrm{Pd}-\mathrm{As}-\mathrm{Sb}$ minerals $(29.3 \%), \mathrm{Pd}-$ Te- (Bi) minerals (12.1\%), RhAsS-IrAsS minerals $(12.1 \%)$, laurite $(6.9 \%)$ alloys $(3.4 \%)$ and $\mathrm{Au}-\mathrm{Ag}$ minerals (5.2\%). The base metal sulphide type mineralization has PGMs associated with both silicates and base metal sulphides.

\section{The AP (Ala-Penikka) reefs}

The AP reefs are present along most of the strike length of the intrusion. They occur in a thick gabbronoritic interval, specifically within and below (but never above) two narrow, but laterally highly continuous anorthosite seams. The closest known analogues are PGE mineralized anorthosites in the Vurechuaivench block of the
Monche pluton, Russia (Pripachkin et al., 2018). A commonality with many other PGE reefs elsewhere is that the AP reefs occur at a stratigraphic level marked by enhanced compositional layering interpreted by most researchers to reflect magma replenishment. However, contrary to most other global reefs, the AP (and SJ) reefs are at the base of reversals towards more fractionated compositions, as expressed by lower $\mathrm{Mg \#}$ and $\mathrm{Cr}$ content. At the same time, the An content of plagioclase in the few AP traverses examined is higher than in the footwall; that is, pyroxene and plagioclase compositions are decoupled (Fig. 8a).

AP1 is normally $20-40 \mathrm{~cm}$ thick and of erratic grade. The PGE mineralization is associated with interstitial sulphides (on average $0.52 \mathrm{wt} \%$ sulphur; Eerola et al., 1990). Average grades are $7 \mathrm{ppm} \mathrm{Pd}$ and $2 \mathrm{ppm} \mathrm{Pt}$, and average metal tenors are $750 \mathrm{ppm} \mathrm{Pt}+\mathrm{Pd}$ (Halkoaho et al., 2005). The Outokumpu Company established a resource of $3.5 \mathrm{mt}$ at $6.16 \mathrm{ppm} \mathrm{Pd}$ and $1.68 \mathrm{ppm} \mathrm{Pt}$, $0.11 \mathrm{ppm} \mathrm{Rh}, 0.28 \mathrm{ppm} \mathrm{Au}$, and $0.21 \mathrm{wt} \% \mathrm{Cu}$ (average reef thickness $73 \mathrm{~cm}$; Eerola et al., 1990). In a detailed traverse across the AP1 reef interval, Halkoaho (1989) showed locally elevated $\mathrm{P}, \mathrm{Zr}$ and $\mathrm{K}$ contents in some, but not all reef samples (Fig. 8a and b). An analogous enrichment in $\mathrm{P}$ and $\mathrm{Zr}$ occurs in a sample of gabbronorite immediately above the APII reef.

Where the AP1 reef is potholed (Fig. 8b), it may be up to $20 \mathrm{~m}$ thick at an average grade of $4 \mathrm{ppm}$ $\mathrm{Pt}+\mathrm{Pd}+\mathrm{Au}$ (Fig. 8a), representing a remarkable $80 \mathrm{ppm}$ PGE normalized to $1 \mathrm{~m}$ (Supplementary Data Electronic Appendices 9 and 10). The pothole is characterized by a number of lithological and compositional anomalies, as follows. (1) The AP1 anorthosite thickens from a few centimetres to $\sim 20 \mathrm{~m}$, but at the same time, the plagioclase content of the rock decreases from $>90 \%$ to $<80 \%$, constituting a gabbronorite. The rock has a 'mottled' texture, with large (up to $>10 \mathrm{~cm}$ ) oikocrysts of pyroxene in a matrix of plagioclase (Fig. 6d) and contains abundant lenses of pegmatoid (Fig. 6f). (2) The density of faults appears to be higher in the vicinity of the pothole (Fig. 8b). (3) Abundant subvertical pegmatoid veins and anorthosite fragments occur $\sim 200 \mathrm{~m}$ above the pothole (Fig. $6 \mathrm{~g}$ ). (4) A dolerite dyke trends through the centre of the pothole (Fig. 8b). (5) Apatite in the vicinity of the pothole has elevated $\mathrm{Cl}$ contents (Halkoaho, 1993). (6) VLF-R and IP-DC measurements indicate a lenticular conductivity anomaly located $\sim 5-$ $10 \mathrm{~m}$ below the pothole and following its contours. The anomaly is $30 \mathrm{~m}$ wide, $100 \mathrm{~m}$ long and up to $200 \mathrm{~m}$ deep (Lerssi, 1990). (7) Some, but not all samples of mineralized anorthosite and some of the roof rocks show a relative enrichment in $\mathrm{P}$ and $\mathrm{Zr}$ (Fig. 8a; Halkoaho et al., 1989b). (8) The hanging wall to the pothole contains barite and $\mathrm{Ni}$-rich chlorite not observed elsewhere in the Penikat intrusion.

The AP2 reef is normally very sulphide-poor and almost barren, but sulphide-rich areas may occur. In one of these areas the reef has an average grade of $11.4 \mathrm{ppm} \mathrm{Pd}$ and $3.4 \mathrm{ppm}$ Pt over a width of several tens 
(a)

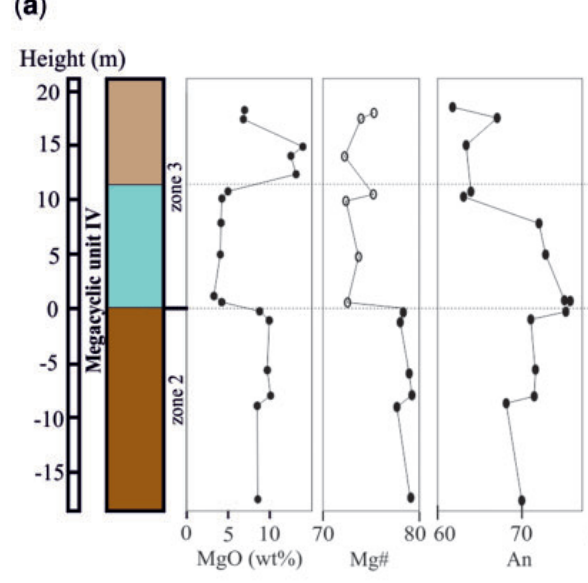

Ki-39

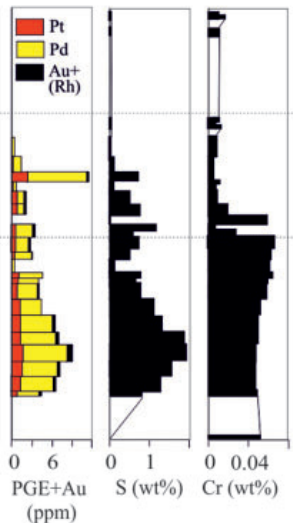

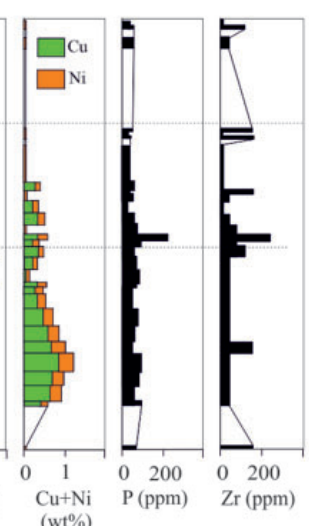

$(\mathrm{wt} \%)$

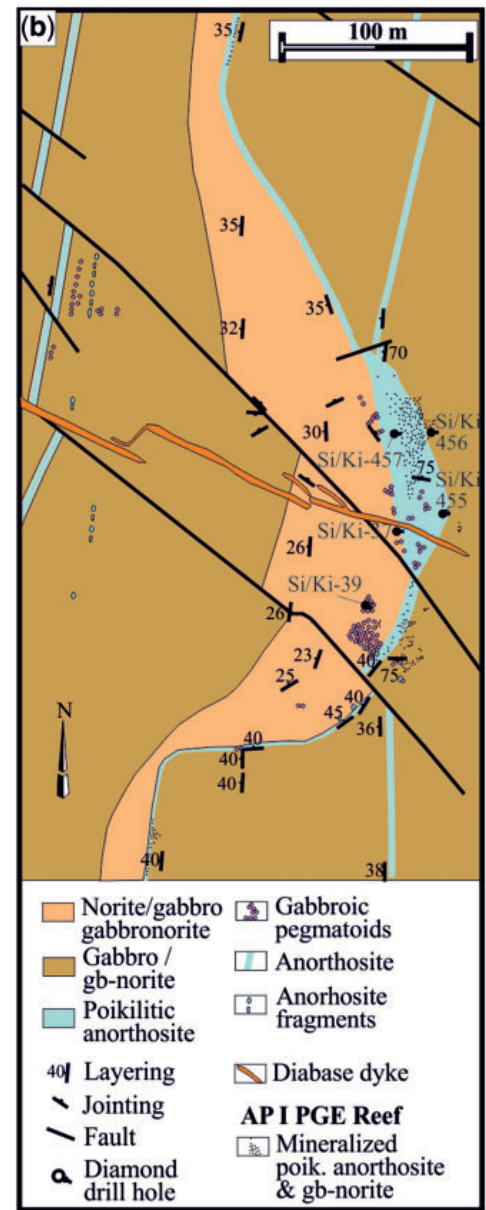

(c)
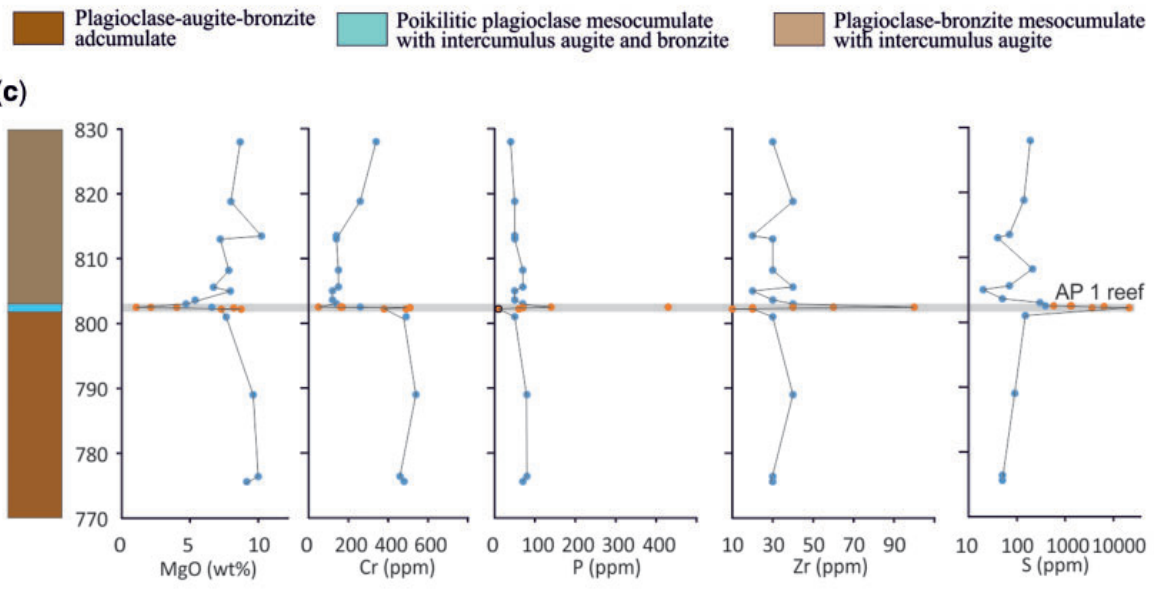

drill hole \& gb-norite

Fig. 8. (a) Stratigraphic variation of selected elements in drillcore SiKi 39 intersecting the AP1 depression structure. It should be noted that in this drillcore PGE-rich sulphides also occur in the gabbronoritic floor rocks to the pothole. Modified after Halkoaho et al. (2005). (b) Map of the large depression structure of the AP1 reef. Cross-cutting relationship of the pothole across several gabbronorite and anorthosite layers, and thickening of sulphidic anorthosite in the centre of the pothole, should be noted. (c) Compositional profile across non-potholed AP1 reef, based on traverse across the reef sampled 200-400 m to the north of the pothole (data from Halkoaho, 1989). The decrease in $\mathrm{Cr}$ above reef, and patchy enrichment of $\mathrm{Zr}$ and $\mathrm{P}$ in reef, should be noted.

of centimetres (Halkoaho et al., 2005) but peak grades of 49 ppm Pd, 9.8 ppm Pt, and 2.07 ppm Au (gabbronorite sample 9383-7202, immediately below the anorthosite). It strongly resembles the AP1 reef in terms of host-rock types. The mineralization is again partly located within a laterally continuous, narrow $(\sim 5 \mathrm{~cm})$ anorthosite (Fig. 6b) and/or in the underlying gabbronorite. On average, AP2 contains less base metal sulphides $(0.35 \mathrm{wt} \% \mathrm{~S})$ than AP1, but locally, sulphide-rich patches may contain several tens of ppm PGE. Average metal tenors are 1600 ppm (Halkoaho et al., 2005). The sulphides in both AP reefs have $\mathrm{Cu} / \mathrm{Ni} 1.4-2.7, \mathrm{Pd} / \mathrm{Pt} 3.7$, and $\mathrm{Pd} / \mathrm{Ir}$ 170-240; that is, the mineralization is of a more differentiated composition than that of the SJ reef.

In the AP reefs, 28 mineral species have been identified (Halkoaho, 1993). The PGM grains investigated vary in diameter from 1 to $65 \mu \mathrm{m}$, the mean being $7 \mu \mathrm{m}$. The dominant PGM are $\mathrm{Pd}-\mathrm{Te}-(\mathrm{Bi})$ minerals $(39.3 \%$ of all grains), sperrylite (20\%), Pd-As-Sb minerals (19.7\%), Pd-Pt sulphides (5.8\%), RhAsS-IrAsS minerals (4.35\%),
Pt-Pd-Te minerals (4.35\%), Pd-As-Te minerals $(2.9 \%)$ and $\mathrm{Au}-\mathrm{Ag}$ minerals (3.6\%). About $70 \%$ of the PGM grains in the AP1 reef were found to occur in association with silicates, $23 \%$ on the edge of base metal sulphide grains and only $7 \%$ as inclusions in sulphides. About $87 \%$ of the PGMs in the AP2 Reef occur in silicates and $13 \%$ in association with sulphides.

\section{The PV (Paasivaara) reef}

In contrast to most other PGE reefs globally, the PV reef is located directly beneath the ultramafic basal portion of a cyclic unit (MCU V). The bulk of the mineralization is hosted within an anorthosite layer that is closely associated with pegmatoidal layers or lenses. The rocks beneath and above the PV reef are relatively heterogenous, displaying strong compositional and lithological variation commonly expressed in the form of a magmatic breccia (the 'mixed horizon'). The reef interval also contains some of the highest concentrations of incompatible elements in the Penikat intrusion, including 
$\mathrm{K}_{2} \mathrm{O}, \mathrm{P}, \mathrm{Pb}$ and $\mathrm{Ag}$, resulting in the occurrence of cumulus apatite and strongly biotite-enriched rocks. At the same time there may be a chromite-enriched zone near the top of the uppermost anorthosite layer (with 1-2 cm sub-rounded patches of chromitite in a $10 \mathrm{~cm}$ sample within drillcore SiKi 403). Finally, the PV reef has a much less fractionated PGE signature, with lower Pd/lr, than the AP reefs, instead resembling that of the ultramafic-hosted SJ reef. Thus, the PV reef displays a remarkable disequilibrium assemblage in terms of lithology and geochemistry.

Although the PV reef has been delineated in most blocks of the intrusion, the drill campaign focused on the Ala-Penikka and Sompujärvi blocks, hence the lateral continuity of grade is less well established than that of the SJ reef (Supplementary Data Electronic Appendix 11). The available data indicate that the PV reef is richest in the Ala-Penikka block, whereas in the Yli-Penikka block it is of lower grade and more heterogeneous. Too few data exist for the Sompujärvi and Kilkka blocks to assess the average grade of the reef in these areas.

A detailed profile across the Transition Zone in the Ala-Penikka block, compiled from two drillcores (SiKi 20 and 21) is shown in Fig. 9 and Supplementary Data Electronic Appendix 12. It is apparent that the Transition Zone forms a compositionally distinct package relative to both the footwall and hanging-wall rocks, with a gradational contact to the former and a sharp contact to the latter. The Transition Zone is characterized by strongly enhanced lithological and chemical variation, expressed by interlayering of mela- and leucogabbroic rocks, anorthosite and pegmatoids with highly variable compositions. The abundance of anorthosite is particularly noteworthy. There are three layers within about $35 \mathrm{~m}$ of stratigraphy, each 1-2 m wide, whereas in the under- and overlying rocks, anorthosite occurs every $150 \mathrm{~m}$ or so. All three anorthosite layers are directly overlain by melanocratic rocks, suggesting a genetic relationship between anorthosite and the melanocratic layers. In general, the rocks of the Transition Zone are less evolved than the footwall rocks (e.g. in terms of Mg\# of augite or An of plagioclase), yet more evolved than the hanging-wall rocks. Notably, some of the plagioclase-rich rocks show a strong enrichment in highly incompatible elements $\mathrm{K}, \mathrm{P}$ and, locally, $\mathrm{Zr}$, and some anorthosites and associated pegmatoids are also enriched in PGE and $\mathrm{Cu}$ (Supplementary Data Electronic Appendix 12). The mineralized zones are separated by several metres of unmineralized or poorly mineralized anorthositic and gabbronoritic rocks. The best PGE grades are found within the uppermost mottled anorthosite (average thickness of mineralization is $\sim 1 \mathrm{~m}$ ). Average grades of this layer are $2.3 \mathrm{ppm}$ for $\mathrm{Pd}$ and $3.9 \mathrm{ppm}$ for $\mathrm{Pt}$ and combined $\mathrm{Pt}+\mathrm{Pd}$ tenors are $280 \mathrm{ppm}$, somewhat lower than in the SJ and AP reefs (Halkoaho et al., 2005). The Outokumpu Company established a resource of $5 \mathrm{mt}$ at $2.58 \mathrm{ppm} \mathrm{Pd}, 4.04 \mathrm{ppm}$ Pt, $0.08 \mathrm{ppm}$ Rh, $0.61 \mathrm{ppm} \mathrm{Au}, 0$, $28 \mathrm{wt} \% \mathrm{Cu}$, and $0.63 \mathrm{wt} \% \mathrm{~S}$ over a reef thickness of

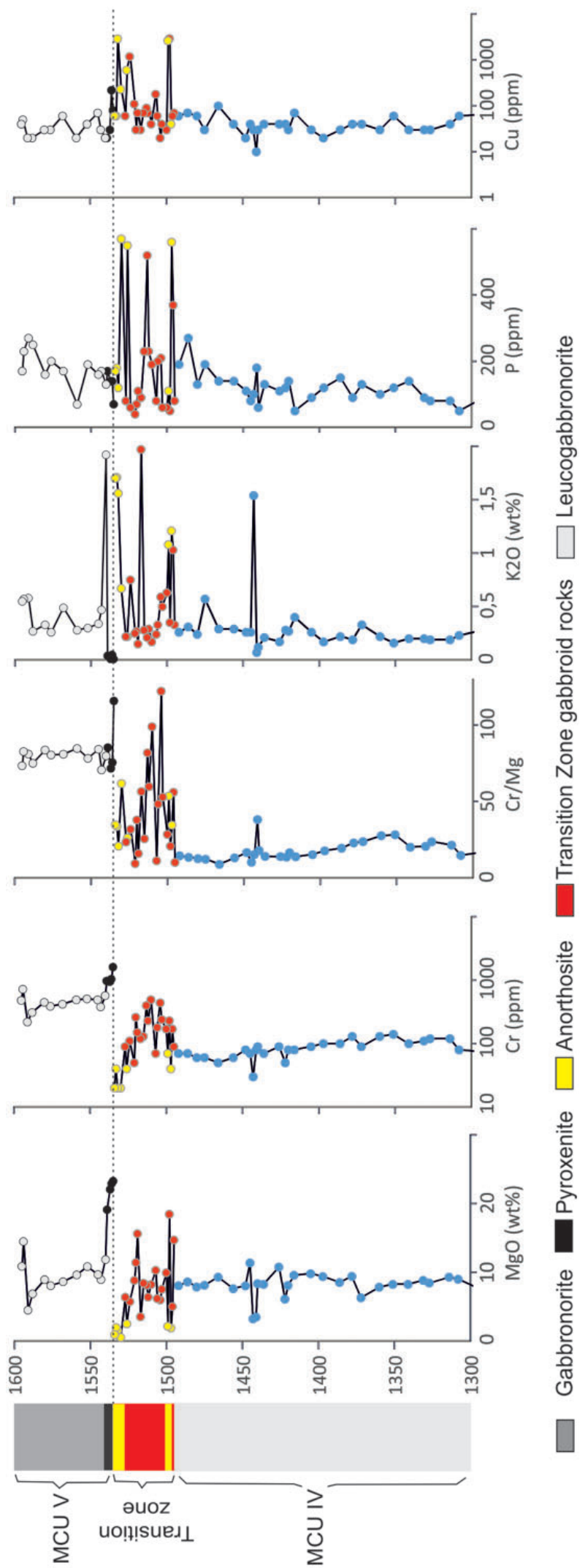

Fig. 9. Compositional variation across the PV reef in the Ala-Penikka block (data from Huhtelin, 1989). It should be noted that the Transition Zone is characterized by a combination of enhanced lithological and compositional variation expressed in layering, as well as enrichment in both compatible and incompatible elements and $\mathrm{Cu}-\mathrm{Ni}$-PGE sulphides. 
$1.09 \mathrm{~m}$ (Eerola et al., 1990). $\mathrm{Cu} / \mathrm{Ni}$ is $\sim 1, \mathrm{Pd} / \mathrm{Ir}$ is 28 , and $\mathrm{Pt} / \mathrm{Pd}$ is $\sim 2$, the last being the highest in the Penikat intrusion.

In the Yli-Penikka block the PV reef occurs within a broad pegmatoidal zone, with anorthosite forming a less continuous layer. Peak grades are $4 \mathrm{ppm} \mathrm{Pt}$, $2.69 \mathrm{ppm} \mathrm{Pd}$ and $0.41 \mathrm{ppm}$ Au over $42 \mathrm{~cm}$. In the Kilkka block the peak grades are Pt $1.50 \mathrm{ppm}, \mathrm{Pd} 0.87 \mathrm{ppm}$ and $\mathrm{Au} 0.11 \mathrm{ppm}$ over $48 \mathrm{~cm}$ and $\mathrm{Pt} 1.3 \mathrm{ppm}, \mathrm{Pd}$ $2.32 \mathrm{ppm}$ and $\mathrm{Au} 0.29 \mathrm{ppm}$ over $78 \mathrm{~cm}$. In the Sompujärvi block, exposed by drillcore Ki-403, the Transition Zone is about $25 \mathrm{~m}$ thick. There is no mixed rock or pegmatoid at all, and incompatible trace elements are not noticeably enriched. There are several anorthosite layers, including a $6 \mathrm{~m}$ seam at the top and several thinner seams (between 10 and $60 \mathrm{~cm}$ thick) below this. PGE are concentrated in a $1 \mathrm{~m}$ interval towards the top of the main anorthosite, notably in the $10 \mathrm{~cm}$ chromite-rich zone at its top contact, with bulk contents of $2.09 \mathrm{ppm} \mathrm{Pd}, 2.49 \mathrm{ppm} \mathrm{Pt}$ and $0.43 \mathrm{ppm} \mathrm{Au}$ (Fig. 10).

\section{SAMPLES}

Most of the samples used in the present study were collected in outcrop during a field excursion in 2011 to the Ala-Penikka block in the southern portion of the intrusion. In addition, eight samples were collected in 2009, focusing on the SJ and AP reef intervals. Most samples weigh between 1 and $2 \mathrm{~kg}$, and their locations are shown in Fig. 11. To study the ultramafic portion of MCU II, we used outcrop and drillcore samples collected in 1982 in the Sompujärvi block. Additional data for drillcores intersecting the SJ and AP reefs are given in Supplementary Data Electronic Appendix 7.

Four gabbro pegmatoid samples have been previously dated using the conventional $\mathrm{U}-\mathrm{Pb}$ thermal ionization mass spectrometry (TIMS) method, all yielding discordant results owing to post-magmatic disturbance (Perttunen \& Vaasjoki, 2001). Using in situ analysis, we re-examined zircon grains from sample A603Oravikangas, for which Perttunen \& Vaasjoki (2001) obtained an imprecise bulk zircon $\mathrm{U}-\mathrm{Pb}$ age of $2428 \pm 35 \mathrm{Ma}$.
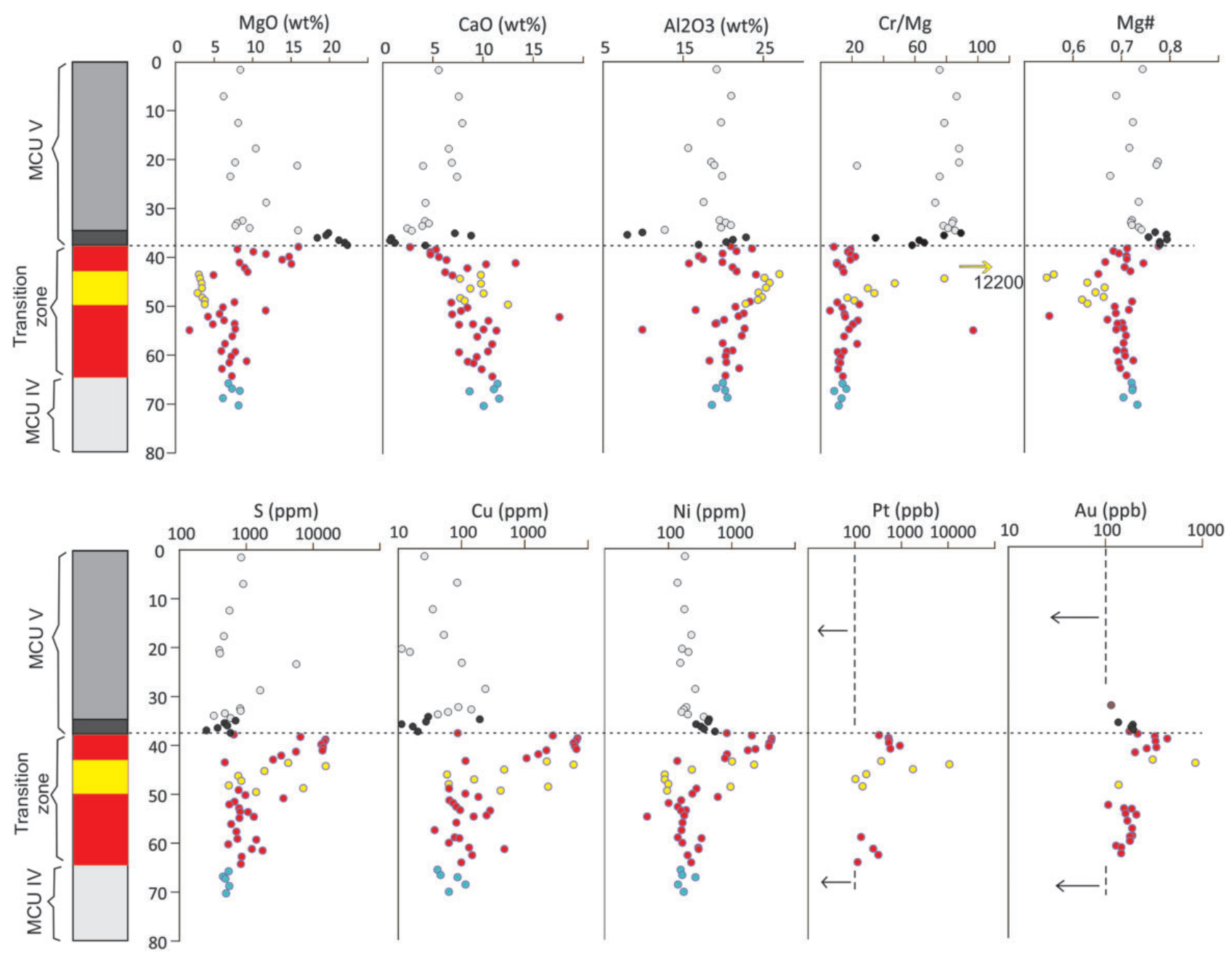

Gabbronorite

Pyroxenite Anorthosite

Transition Zone gabbroid rocks

Leucogabbronorite

Fig. 10. Drillcore profile SiKi 403 across the Transition Zone and the PV reef in the Sompujärvi block. 


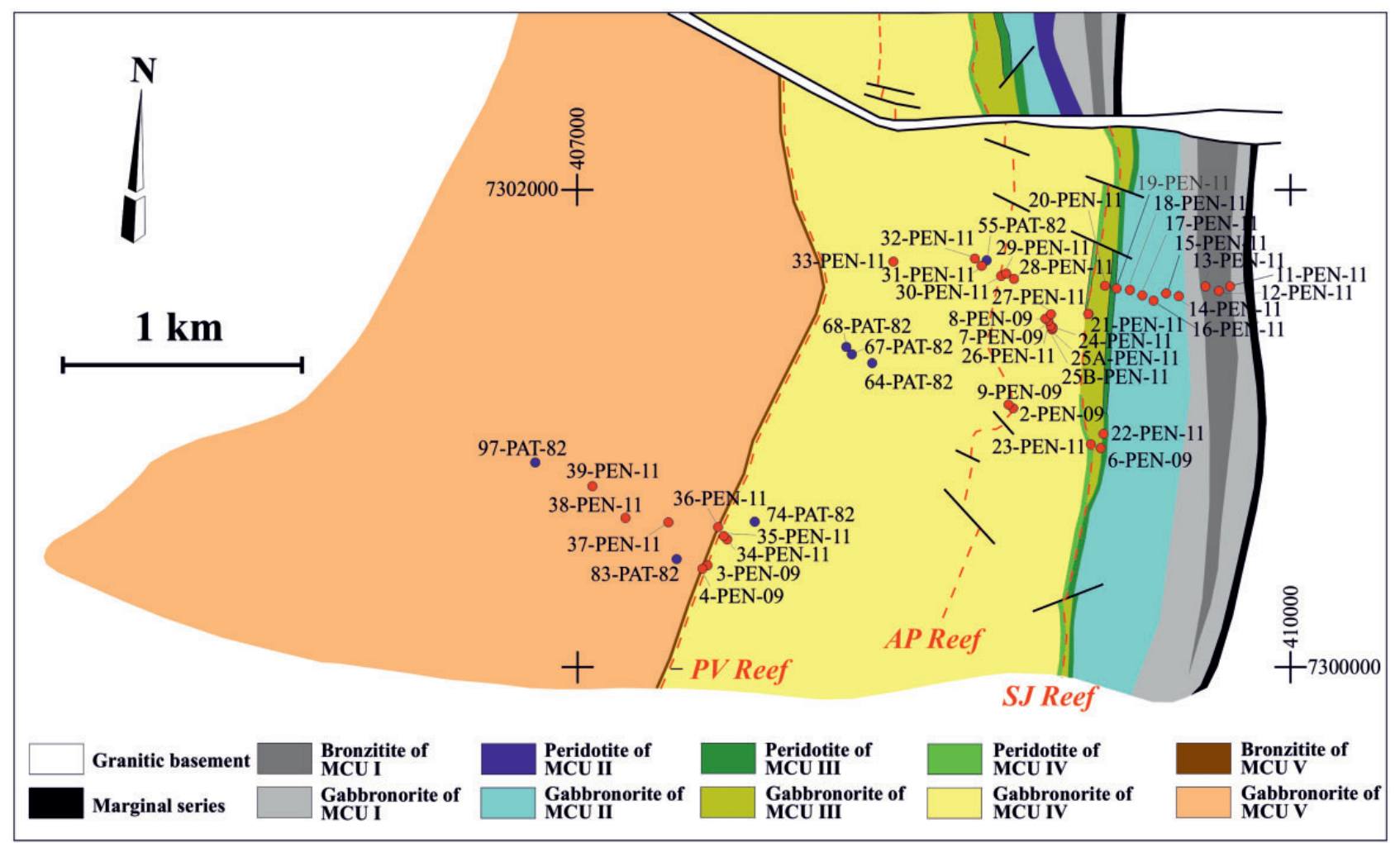

Fig. 11. Geological map of the Ala-Penikka block, showing sample sites for this study. The positions of the PGE reefs are shown by red dashed line.

\section{ANALYTICAL METHODS}

After the preparation of thin sections at the University of Oulu, the samples were milled in an alumina vessel. The samples were analysed for major elements and a range of lithophile minor and trace elements including $\mathrm{Sr}, \mathrm{Rb}, \mathrm{Nb}, \mathrm{Y}, \mathrm{Zr}, \mathrm{Ni}, \mathrm{Cu}, \mathrm{Zn}, \mathrm{Co}, \mathrm{Cr}, \mathrm{Sc}, \mathrm{V}$ and REE using inductively coupled plasma optical emission spectrometry (ICP-OES) and inductively coupled plasma mass spectrometry (ICP-MS) at Cardiff University, UK. Full details of the analytical procedures have been given by McDonald \& Viljoen (2006). The concentrations of the platinum-group elements were determined at the University of Quebec in Chicoutimi (UOAC), Canada, using ICP-MS after Ni sulphide fire assay and Te co-precipitation [see Savard et al. (2010) for analytical details]. Details of analytical accuracy and precision are given in Table 2. Selenium was determined by thiol cotton fibre instrumental neutron activation (TCF-INAA) at UQAC [see Savard et al. (2006) for method description]. All data are provided in Table 3.

The $\mathrm{Sm}-\mathrm{Nd}$ isotope analyses were performed at the Geological Survey of Finland (GTK) in Espoo, using isotope dilution (ID) and TIMS (VG Sector 54). Between 120 and $200 \mathrm{mg}$ of powdered sample were spiked with a ${ }^{149} \mathrm{Sm}^{-150} \mathrm{Nd}$ tracer. The sample-spike mixture was dissolved in $\mathrm{HF}-\mathrm{HNO}_{3}$ in Savillex screw-cap beakers on a hot plate for $48 \mathrm{~h}$. After evaporation of fluorides, the residue was dissolved in $6 \mathrm{~N} \mathrm{HCl}$ and a clear solution was achieved. Samarium and $\mathrm{Nd}$ were separated in two stages using a conventional cation exchange procedure with $7 \mathrm{ml}$ of AG50Wx8 ion exchange resin in a bed of $12 \mathrm{~cm}$ length, and a modified version of the TeflonHDEHP hydrogen diethylhexyl phosphate method developed by Richard et al. (1976). The measurements were made in dynamic mode on a VG SECTOR 54 mass spectrometer using Ta-Re triple filaments. The ${ }^{143} \mathrm{Nd} /{ }^{144} \mathrm{Nd}$ ratio was normalized to ${ }^{146} \mathrm{Nd} /{ }^{144} \mathrm{Nd}=0.7219$. The longterm average ${ }^{143} \mathrm{Nd} /{ }^{144} \mathrm{Nd}$ for the La Jolla standard is $0.511849 \pm 0.000013$ (standard deviation for 130 measurements during the years 2008-2011). During 2013, the average ${ }^{143} \mathrm{Nd} / /^{144} \mathrm{Nd}$ for the La Jolla standard was $0.511851 \pm 0.000009(n=85)$. The $\mathrm{Sm} / \mathrm{Nd}$ ratio of the spike was calibrated against the Caltech mixed $\mathrm{Sm} / \mathrm{Nd}$ standard (Wasserburg et al., 1981). Based on duplicate analyses, the error in ${ }^{147} \mathrm{Sm} /{ }^{144} \mathrm{Nd}$ is estimated to be $0.4 \%$. Initial ${ }^{143} \mathrm{Nd} /{ }^{144} \mathrm{Nd}$ ratios and $\varepsilon \mathrm{Nd}$ values were calculated using the following parameters: $\lambda^{147} \mathrm{Sm}=$ $6.54 \times 10^{-12} \mathrm{a}^{-1},{ }^{147} \mathrm{Sm} /{ }^{144} \mathrm{Nd}=0.1966$ and ${ }^{143} \mathrm{Nd} /{ }^{144} \mathrm{Nd}=$ 0.51264 for present CHUR. Depleted mantle model ages ( $\left.T_{D M}\right)$ were calculated according to DePaolo (1981). Measurements on the rock standard BCR-1 (e.g. Weis et al., 2006) provided the following values: $\mathrm{Sm}=$ $6.58 \mathrm{ppm}, \mathrm{Nd}=28.8 \mathrm{ppm},{ }^{147} \mathrm{Sm} /{ }^{144} \mathrm{Nd}=0.1380,{ }^{143} \mathrm{Nd} /$ ${ }^{144} \mathrm{Nd}=0.51264 \pm 0.00002$. Total procedural blank was $<0.5 \mathrm{ng}$ for Nd by mass spectrometry at GTK. All Nd isotope data are shown in Table 4.

The U-Pb analyses were carried out using a $\mathrm{Nu}$ Plasma AttoM single-collector ICP-MS system 
Table 2: Estimate of accuracy and precision based on results for international reference material determined at UQAC

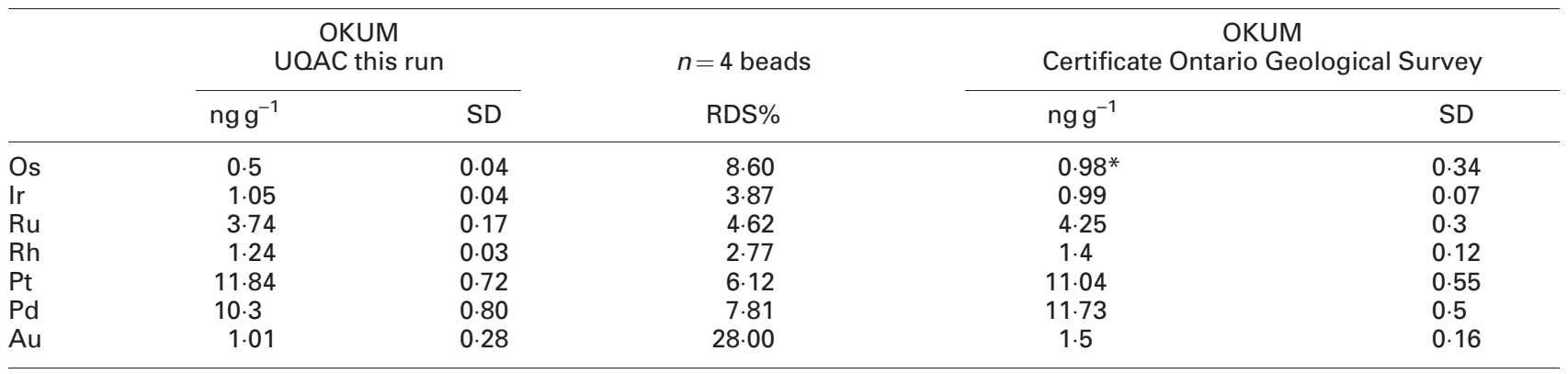

*Savard et al. (2010).

connected to a Photon Machine Analyte G2 laser ablation (LA) system at the Finnish Isotope Geosciences Laboratory (SIGL) located in the Geological Survey of Finland, Espoo. Samples were ablated in He gas (gas flows $=0.4$ and $0.1\left(\mathrm{~min}^{-1}\right.$ ) within a HelEx ablation cell (Müller et al., 2009). The He aerosol was mixed with $\mathrm{Ar}$ (gas flow $=0.81 \mathrm{~min}^{-1}$ ) prior to entry into the plasma. The gas mixture was optimized daily for maximum sensitivity. Typical ablation conditions were beam diameter $25 \mu \mathrm{m}$, pulse frequency $5 \mathrm{~Hz}$ and beam energy density $2 \mathrm{~J} \mathrm{~cm}^{-2}$. A single $\mathrm{U}-\mathrm{Pb}$ measurement included a short pre-ablation, $10 \mathrm{~s}$ of on-mass background measurement followed by $30 \mathrm{~s}$ of ablation with a stationary beam. ${ }^{235} \mathrm{U}$ was calculated from the signal at mass 238 using a natural ${ }^{238} \mathrm{U} /{ }^{235} \mathrm{U}=137.88$ (Ludwig, 2003). Mass number 204 was used as a monitor for common ${ }^{204} \mathrm{~Pb}$. In an ICPMS analysis, ${ }^{204} \mathrm{Hg}$ mainly originates from the He supply. The observed background counting-rate on mass 204 was $150-200$ c.p.s. The contribution of ${ }^{204} \mathrm{Hg}$ from the plasma was eliminated by on-mass background measurement prior to each analysis. Age-related common lead (Stacey \& Kramers, 1975) correction was used when the analysis showed common lead contents above the detection limit. Signal strengths on mass 206 were typically 100000 c.p.s., depending on the uranium content and age of the zircon.

Two calibration standards were run at the beginning and end of each analytical session, and at regular intervals during sessions. Raw data were corrected for the background, laser-induced elemental fractionation, mass discrimination and drift in ion counter gains, and reduced to $\mathrm{U}-\mathrm{Pb}$ isotope ratios by calibration to concordant reference zircons of known age, using protocols adapted from Andersen et al. (2004) and Jackson et al. (2004). The calculations were performed off-line, using an interactive spreadsheet program written in Microsoft Excel/VBA by T. Andersen (Rosa et al., 2009). In-house standard zircons A382 (1877 $\pm 2 \mathrm{Ma})$ and A1772 (2712 $\pm 1 \mathrm{Ma}$, Huhma et al., 2012) were used for calibration. To minimize the effects of laser-induced elemental fractionation, the depth-to-diameter ratio of the ablation pit was kept low, and isotopically homogeneous segments of the time-resolved traces were calibrated against the corresponding time interval for each mass in the reference zircon. Plotting of the $\mathrm{U}-\mathrm{Pb}$ isotopic data and age calculations were performed using the Isoplot/Ex 3 program (Ludwig, 2003). All the ages were calculated with $2 \sigma$ errors and without decay constants errors. Data-point error ellipses in the figures are at the $2 \sigma$ level. The ${ }^{207} \mathrm{~Pb} /{ }^{206} \mathrm{~Pb}$ age offset from concordant IDTIMS ages for several samples does not exceed $0.5 \%$.

\section{RESULTS}

\section{Geochronology}

To refine the age of sample A603-Oravikangas from the Penikat intrusion, studied earlier by Perttunen \& Vaasjoki (2001), 18 single zircon grains were analysed using LA-ICP-MS. The results are shown in Table 5 and plotted in Fig. 12. All measured compositions plot at or close to the concordia curve. Excluding the two most discordant analyses, the data yield an age of $2444 \pm 8 \mathrm{Ma}(2 \sigma)$, which is more precise than the TIMS age of $2428 \pm 35 \mathrm{Ma}$ proposed by Perttunen \& Vaasjoki (2001) based on five analyses of discordant baddeleyite.

\section{Lithophile element geochemistry}

In the absence of preserved primary minerals in many of the rocks, the mineralogy of the samples has been deduced based on major element compositions, which are largely controlled by variations in the modal proportions of the major silicate minerals. A plot of $\mathrm{CaO}$ vs $\mathrm{MgO}$ (Fig. 13a) shows that the analysed ultramafic rocks comprise mainly Iherzolites, olivine orthopyroxenites and websterites. Wehrlites are rare and dunites are absent. The $\mathrm{Al}_{2} \mathrm{O}_{3}$ vs $\mathrm{MgO}$ plot (Fig. 13b) indicates that the proportion of intercumulus plagioclase in several of the ultramafic rocks is slightly higher than $10 \%$. The mafic rocks consist of gabbronorites, norites and anorthosites. Gabbros appear to be rare. Most of the mafic rocks have more than $50 \%$ plagioclase, and there are few mesogabbroic rocks, analogous to, for example, the Bushveld Complex, where this was termed the 'melanorite gap' by Maier \& Eales (1997). Chromite is an accessory phase in many of the samples, irrespective of rock type (Fig. 13c). In the gabbroic rocks, magnetite may account for some of the $\mathrm{Cr}$ budget. Assuming that the parental magma was a siliceous high-magnesian basalt (SHMB) containing $70 \mathrm{ppm} \mathrm{Zr}$ (as discussed 
Table 3: Whole-rock compositional data from Penikat intrusion

\begin{tabular}{|c|c|c|c|c|c|c|c|c|c|c|}
\hline $\begin{array}{l}\text { Block: } \\
\text { Sample no.: }\end{array}$ & $\begin{array}{l}\text { Ala-Pen } \\
11 \text { PEN }\end{array}$ & $\begin{array}{l}\text { Ala-Pen } \\
12 \text { PEN }\end{array}$ & $\begin{array}{l}\text { Ala-Pen } \\
13 \text { PEN }\end{array}$ & $\begin{array}{l}\text { Keski-Pen } \\
\text { 107B PAT }\end{array}$ & $\begin{array}{c}\text { Sompuj } \\
\text { SiKi7-268.16 }\end{array}$ & $\begin{array}{l}\text { Keski-Pen } \\
\text { 108B PAT }\end{array}$ & $\begin{array}{c}\text { Sompuj } \\
\text { SiKi7-209.61 }\end{array}$ & $\begin{array}{c}\text { Sompuj } \\
\text { SiKi7-195.9 }\end{array}$ & $\begin{array}{c}\text { Sompuj } \\
\text { Siki7-192.4 }\end{array}$ & $\begin{array}{c}\text { Ala-Pen } \\
14 \text { PEN }\end{array}$ \\
\hline $\begin{array}{l}\text { Height (above } \\
\text { base, m): }\end{array}$ & 50 & 90 & 130 & 165 & 170 & 185 & 200 & 207 & 208.5 & 220 \\
\hline Sample type: & Outcrop & Outcrop & Outcrop & Outcrop & drillcore & Outcrop & drillcore & drillcore & drillcore & Outcrop \\
\hline Rock type & Opx & Opx & Opx & Webs & Ol-opx & Ol-opx & Webs & Ol-opx & Ol-opx & GN \\
\hline MCU: & $\mathrm{i}$ & $\mathrm{i}$ & i & II & II & II & II & II & II & II \\
\hline \multicolumn{11}{|l|}{$w t \%$} \\
\hline $\mathrm{SiO}_{2}$ & $51 \cdot 32$ & $50 \cdot 45$ & $50 \cdot 70$ & $46 \cdot 48$ & 35.76 & 39.64 & 50.51 & 40.93 & 39.28 & $50 \cdot 79$ \\
\hline $\mathrm{TiO}_{2}$ & 0.29 & 0.14 & 0.25 & 0.20 & 0.25 & 0.09 & 0.08 & 0.10 & 0.07 & 0.23 \\
\hline $\mathrm{Al}_{2} \mathrm{O}_{3}$ & $5 \cdot 26$ & $6 \cdot 30$ & 5.58 & 5.46 & 5.85 & $3 \cdot 26$ & 2.98 & $5 \cdot 27$ & 4.45 & 14.56 \\
\hline $\mathrm{Fe}_{2} \mathrm{O}_{3}$ & $10 \cdot 85$ & 10.95 & $12 \cdot 25$ & 8.61 & $17 \cdot 83$ & 15.03 & 8.08 & 11.29 & 17.99 & 7.00 \\
\hline $\mathrm{MnO}$ & 0.22 & 0.22 & 0.23 & 0.21 & 0.33 & 0.16 & 0.13 & 0.14 & 0.15 & 0.15 \\
\hline $\mathrm{MgO}$ & 22.90 & $23 \cdot 32$ & 21.28 & 19.49 & $25 \cdot 58$ & 29.38 & 22.49 & 23.54 & 20.96 & $9 \cdot 79$ \\
\hline $\mathrm{CaO}$ & 4.70 & 5.57 & $5 \cdot 78$ & $16 \cdot 26$ & 2.59 & 2.99 & $10 \cdot 24$ & 6.95 & 8.87 & $14 \cdot 10$ \\
\hline $\mathrm{Na}_{2} \mathrm{O}$ & 0.68 & 0.69 & 0.38 & 0.33 & 0.09 & 0.08 & 0.12 & $0 \cdot 10$ & 0.11 & 1.58 \\
\hline $\mathrm{K}_{2} \mathrm{O}$ & $0 \cdot 18$ & 0.23 & 0.08 & 0.02 & 0.00 & 0.00 & 0.01 & 0.00 & 0.00 & $0 \cdot 13$ \\
\hline $\mathrm{P}_{2} \mathrm{O}_{5}$ & 0.05 & 0.01 & 0.05 & 0.00 & 0.01 & 0.00 & 0.01 & 0.00 & 0.00 & 0.02 \\
\hline $\mathrm{Cr}_{2} \mathrm{O}_{3}$ & 0.57 & 0.35 & 0.34 & 0.41 & $6 \cdot 12$ & 0.54 & 1.92 & 0.74 & 0.39 & 0.19 \\
\hline LOI & $3 \cdot 15$ & 0.88 & 3.59 & 3.04 & $6 \cdot 86$ & $9 \cdot 14$ & $2 \cdot 20$ & $10 \cdot 48$ & $7 \cdot 31$ & 0.60 \\
\hline Total & $100 \cdot 18$ & $99 \cdot 12$ & $100 \cdot 50$ & $100 \cdot 52$ & $101 \cdot 26$ & $100 \cdot 32$ & 98.77 & 99.53 & 99.58 & $99 \cdot 16$ \\
\hline \multicolumn{11}{|l|}{ ppm } \\
\hline Sc & 29 & 28 & 34 & 42 & 23 & 13 & 25 & 20 & 16 & 34 \\
\hline V & 143 & 79 & 111 & 105 & 262 & 62 & 86 & 77 & 72 & 118 \\
\hline $\mathrm{Cr}$ & 3915 & 2372 & 2304 & 2798 & 41894 & 3721 & 13116 & 5048 & 2703 & 1283 \\
\hline Co & 91 & 90 & 98 & 89 & 161 & 128 & 109 & 99 & 107 & 50 \\
\hline $\mathrm{Ni}$ & 272 & 271 & 245 & 455 & 502 & 622 & 434 & 509 & 524 & 130 \\
\hline $\mathrm{Cu}$ & 108 & 150 & 60 & 64 & 26 & 115 & 859 & 26 & 228 & 235 \\
\hline $\mathrm{Zn}$ & 90 & 73 & 110 & 27 & 251 & 38 & 79 & 51 & 40 & 45 \\
\hline Ga & $8 \cdot 1$ & 6.7 & 7.6 & $7 \cdot 1$ & $11 \cdot 1$ & 5.7 & 5.7 & 5.9 & $6 \cdot 1$ & 11.3 \\
\hline $\mathrm{Rb}$ & 7.4 & $10 \cdot 0$ & $4 \cdot 2$ & $2 \cdot 4$ & $2 \cdot 3$ & 0.3 & 0.9 & 0.4 & 0.3 & $2 \cdot 4$ \\
\hline $\mathrm{Sr}$ & 97 & 105 & 25 & 57 & 4 & 12 & 21 & 46 & 46 & 225 \\
\hline Y & 7.5 & 3.4 & $7 \cdot 1$ & 6.0 & 4.0 & 3.6 & 2.5 & $3 \cdot 2$ & 4.6 & $5 \cdot 8$ \\
\hline $\mathrm{Zr}$ & 32.7 & 15.5 & 20.3 & 14.1 & 13.9 & 11.9 & 8.6 & 11.1 & $16 \cdot 2$ & 20.8 \\
\hline $\mathrm{Nb}$ & $2 \cdot 1$ & $4 \cdot 1$ & 1.7 & 1.0 & 0.8 & 0.7 & 0.6 & 0.8 & 0.7 & 1.3 \\
\hline Mo & 0.56 & 0.57 & 0.53 & 0.56 & 0.48 & 0.45 & 0.62 & 0.44 & 0.44 & 0.55 \\
\hline $\mathrm{Sn}$ & 0.35 & 0.52 & 0.58 & 0.32 & 0.36 & 0.20 & 0.19 & 0.30 & 0.32 & 0.49 \\
\hline Cs & 0.38 & 0.25 & 0.53 & 0.27 & 0.09 & 0.05 & 0.06 & 0.05 & 0.04 & 0.18 \\
\hline $\mathrm{Ba}$ & 84 & 79 & 57 & 38 & 2 & 24 & 4 & 7 & 5 & 81 \\
\hline La & 4.18 & 1.74 & $3 \cdot 22$ & 1.86 & 0.78 & 1.76 & 0.49 & 1.72 & 1.28 & 2.58 \\
\hline $\mathrm{Ce}$ & 9.04 & 3.51 & 6.56 & 4.29 & $2 \cdot 13$ & 3.43 & 1.01 & 3.62 & 3.03 & $5 \cdot 82$ \\
\hline $\operatorname{Pr}$ & 1.17 & 0.44 & 0.92 & 0.61 & 0.31 & 0.46 & 0.17 & 0.45 & 0.42 & 0.76 \\
\hline $\mathrm{Nd}$ & $4 \cdot 71$ & 1.79 & 3.79 & 2.78 & 1.43 & 1.86 & 0.87 & 1.88 & 1.91 & 3.45 \\
\hline Sm & 1.09 & 0.40 & 0.95 & 0.80 & 0.38 & 0.38 & 0.28 & 0.42 & 0.50 & 0.88 \\
\hline Eu & 0.35 & 0.21 & 0.26 & 0.35 & 0.11 & 0.13 & 0.05 & 0.15 & 0.12 & 0.36 \\
\hline $\mathrm{Gd}$ & 1.08 & 0.40 & 0.96 & 0.78 & 0.45 & 0.47 & 0.27 & 0.44 & 0.49 & 0.84 \\
\hline Tb & 0.17 & 0.07 & 0.17 & 0.15 & 0.08 & 0.07 & 0.05 & 0.07 & 0.10 & 0.14 \\
\hline Dy & 1.10 & 0.48 & 1.10 & 0.94 & 0.52 & 0.49 & 0.37 & 0.46 & 0.63 & 0.93 \\
\hline Ho & 0.22 & $0 \cdot 10$ & 0.22 & 0.20 & $0 \cdot 10$ & 0.09 & 0.07 & 0.09 & 0.12 & $0 \cdot 19$ \\
\hline $\mathrm{Er}$ & 0.67 & 0.32 & 0.72 & 0.57 & 0.33 & 0.29 & 0.22 & 0.28 & 0.35 & 0.55 \\
\hline Tm & 0.11 & 0.06 & 0.12 & 0.09 & 0.05 & 0.05 & 0.04 & 0.05 & 0.06 & 0.09 \\
\hline $\mathrm{Yb}$ & 0.71 & 0.38 & 0.73 & 0.58 & 0.32 & 0.30 & 0.23 & 0.27 & 0.36 & 0.54 \\
\hline Lu & 0.10 & 0.05 & 0.11 & 0.09 & 0.05 & 0.05 & 0.03 & 0.05 & 0.06 & 0.08 \\
\hline $\mathrm{Hf}$ & 0.88 & 0.42 & 0.60 & 0.41 & 0.37 & 0.32 & 0.26 & 0.34 & 0.39 & 0.61 \\
\hline $\mathrm{Ta}$ & 0.14 & 0.23 & 0.12 & 0.07 & 0.04 & 0.04 & 0.03 & 0.06 & 0.05 & 0.08 \\
\hline Th & 0.95 & 0.45 & 0.74 & 0.29 & 0.28 & 0.28 & 0.27 & 0.34 & 0.26 & 0.43 \\
\hline U & 0.14 & 0.08 & 0.13 & 0.04 & 0.05 & 0.05 & 0.04 & 0.07 & 0.06 & 0.06 \\
\hline C & 119 & 102 & 194 & 387 & 314 & 2751 & 290 & 16945 & 13645 & 123 \\
\hline \multirow{2}{*}{\multicolumn{11}{|c|}{$p p b$}} \\
\hline & & & & & & & & & & \\
\hline $\mathrm{Se}$ & n.d. & n.d. & $48 \cdot 8$ & n.d. & n.d. & n.d. & n.d. & n.d. & n.d. & n.d. \\
\hline Os & 0.50 & 0.72 & 0.30 & 0.25 & 1.97 & 0.65 & 4.07 & 0.13 & 0.17 & $<0.065$ \\
\hline Ir & 0.90 & 1.82 & $2 \cdot 27$ & $4 \cdot 12$ & $43 \cdot 36$ & 9.62 & 33.81 & 3.51 & $2 \cdot 27$ & 0.18 \\
\hline $\mathrm{Ru}$ & $2 \cdot 35$ & $2 \cdot 77$ & 1.81 & 0.80 & 7.67 & 2.61 & 14.46 & 0.89 & 0.73 & $<0.12$ \\
\hline $\mathrm{Rh}$ & 1.71 & $2 \cdot 66$ & $5 \cdot 29$ & 16.64 & 146.64 & 28.79 & 64.54 & $10 \cdot 69$ & 7.56 & 0.43 \\
\hline $\mathrm{Pt}$ & $5 \cdot 6$ & $5 \cdot 6$ & $20 \cdot 1$ & 88.5 & $450 \cdot 6$ & 56.9 & $56 \cdot 0$ & $39 \cdot 3$ & $30 \cdot 8$ & $4 \cdot 0$ \\
\hline $\mathrm{Pd}$ & 3.4 & 5.6 & $6 \cdot 3$ & 21.0 & $226 \cdot 0$ & 31.5 & 28.6 & $77 \cdot 2$ & $99 \cdot 1$ & $4 \cdot 6$ \\
\hline $\mathrm{Au}$ & 1.53 & 5.02 & 1.52 & 0.79 & 4.33 & 1.49 & 0.65 & 1.45 & 3.41 & 0.70 \\
\hline eNd & n.d. & -1.8 & n.d. & n.d. & n.d. & n.d. & n.d. & n.d. & n.d. & n.d. \\
\hline
\end{tabular}

(continued) 
Table 3: Continued

\begin{tabular}{|c|c|c|c|c|c|c|c|c|c|c|c|}
\hline $\begin{array}{l}\text { Ala-Pen } \\
15 \text { PEN } \\
260 \\
\text { Outcrop } \\
\text { GN } \\
\text { II }\end{array}$ & $\begin{array}{c}\text { Ala-Pen } \\
16 \text { PEN } \\
305 \\
\text { Outcrop } \\
\text { GN } \\
\text { II }\end{array}$ & $\begin{array}{c}\text { Ala-Pen } \\
17 \text { PEN } \\
345 \\
\text { Outcrop } \\
\text { GN } \\
\text { II }\end{array}$ & $\begin{array}{c}\text { Ala-Pen } \\
18 \text { PEN } \\
385 \\
\text { Outcrop } \\
\text { GN } \\
\text { II }\end{array}$ & $\begin{array}{c}\text { Ala-Pen } \\
19 \text { PEN } \\
425 \\
\text { Outcrop } \\
\text { GN } \\
\text { II }\end{array}$ & $\begin{array}{c}\text { Ala-Pen } \\
116 \text { PAT } \\
455 \\
\text { Outcrop } \\
\text { Ol-opx } \\
\text { III }\end{array}$ & $\begin{array}{c}\text { Ala-Pen } \\
22 \text { PEN } \\
460 \\
\text { Outcrop } \\
\text { Ol-opx } \\
\text { III }\end{array}$ & $\begin{array}{c}\text { Ala-Pen } \\
6 \text { Pen } \\
465 \\
\text { Outcrop } \\
\text { GN } \\
\text { III }\end{array}$ & $\begin{array}{c}\text { Ala-Pen } \\
20 \text { PEN } \\
470 \\
\text { Outcrop } \\
\text { GN } \\
\text { III }\end{array}$ & $\begin{array}{c}\text { Ala-Pen } \\
21 \text { PEN } \\
520 \\
\text { Outcrop } \\
\text { GN } \\
\text { III }\end{array}$ & $\begin{array}{c}\text { Sompuj } \\
\text { SiKi2-160-76 } \\
545 \\
\text { drillcore } \\
\text { GN } \\
\text { III }\end{array}$ & $\begin{array}{c}\text { Ala-Pen } \\
23 \text { PEN } \\
551 \\
\text { Outcrop } \\
\text { Ol-opx } \\
\text { IV }\end{array}$ \\
\hline 51.00 & 50.99 & $49 \cdot 76$ & 48.62 & $50 \cdot 14$ & $45 \cdot 94$ & 32.65 & 48.40 & $51 \cdot 36$ & 50.90 & 43.42 & 46.69 \\
\hline 0.13 & 0.15 & 0.16 & $0 \cdot 10$ & 0.11 & 0.12 & 0.19 & $0 \cdot 10$ & $0 \cdot 10$ & 0.25 & 0.13 & 0.11 \\
\hline $17 \cdot 33$ & $16 \cdot 19$ & $18 \cdot 75$ & 16.91 & $17 \cdot 28$ & 5.97 & $15 \cdot 02$ & 15.60 & $16 \cdot 21$ & $18 \cdot 87$ & 9.04 & 5.89 \\
\hline $5 \cdot 61$ & $5 \cdot 27$ & 4.65 & 5.94 & 4.57 & $10 \cdot 62$ & 11.50 & $5 \cdot 70$ & $5 \cdot 10$ & 5.82 & $13 \cdot 12$ & 8.35 \\
\hline $0 \cdot 12$ & 0.12 & $0 \cdot 10$ & 0.12 & $0 \cdot 10$ & 0.14 & 0.11 & 0.11 & 0.11 & $0 \cdot 10$ & 0.14 & 0.15 \\
\hline 11.27 & $10 \cdot 82$ & $9 \cdot 37$ & 13.94 & 11.23 & $27 \cdot 14$ & 28.93 & $12 \cdot 40$ & $10 \cdot 66$ & 7.42 & 20.97 & 25.06 \\
\hline 11.64 & $13 \cdot 30$ & $13 \cdot 13$ & 11.33 & $13 \cdot 16$ & $10 \cdot 77$ & 0.81 & 13.98 & 14.31 & 12.72 & 4.74 & $6 \cdot 84$ \\
\hline 1.76 & 1.41 & 1.74 & 1.15 & 1.16 & 0.17 & $0 \cdot 10$ & 1.11 & 1.20 & 1.93 & 0.01 & 0.12 \\
\hline 0.16 & 0.22 & 0.13 & 0.11 & 0.22 & $<0.01$ & 0.01 & 0.36 & 0.09 & 0.20 & 0.01 & 0.01 \\
\hline 0.00 & 0.01 & 0.01 & 0.01 & 0.00 & 0.02 & 0.02 & $<0.01$ & 0.00 & 0.02 & 0.02 & 0.01 \\
\hline 0.24 & 0.22 & 0.17 & 0.13 & 0.12 & 0.48 & 0.07 & n.d. & 0.23 & 0.07 & n.d. & 0.93 \\
\hline 1.65 & 0.57 & 1.26 & 2.51 & 1.54 & n.d. & 10.55 & n.d. & 0.92 & 0.86 & $7 \cdot 26$ & 4.86 \\
\hline $100 \cdot 91$ & 99.27 & $99 \cdot 23$ & $100 \cdot 86$ & 99.64 & $101 \cdot 36$ & 99.98 & $97 \cdot 76$ & $100 \cdot 29$ & $99 \cdot 14$ & 98.85 & 99.01 \\
\hline 25 & 32 & 27 & 20 & 24 & n.d. & 27 & 29 & 30 & 29 & 12 & 16 \\
\hline 77 & 83 & 88 & 69 & 72 & 80 & 96 & 90 & 84 & 119 & 44 & 86 \\
\hline 1650 & 1503 & 1173 & 871 & 842 & 3280 & 471 & 809 & 1550 & 483 & 382 & 6371 \\
\hline 48 & 47 & 49 & 60 & 49 & n.d. & 117 & 43 & 42 & 32 & 109 & 110 \\
\hline 154 & 136 & 130 & 277 & 142 & 690 & 238 & 244 & 150 & 109 & 1017 & 1179 \\
\hline 109 & 72 & 158 & 95 & 149 & 210 & 55 & $<20$ & 147 & 118 & 32 & 243 \\
\hline 34 & 24 & 44 & 33 & 22 & n.d. & 52 & n.d. & 24 & 31 & 46 & 66 \\
\hline $12 \cdot 8$ & 10.9 & 12.2 & 10.9 & $10 \cdot 3$ & n.d. & $12 \cdot 3$ & n.d. & 9.7 & 14.2 & $6 \cdot 7$ & 6.9 \\
\hline 3.7 & 5.7 & $3 \cdot 4$ & $1 \cdot 8$ & $6 \cdot 1$ & n.d. & 0.5 & $17 \cdot 1$ & 1.1 & $3 \cdot 3$ & 0.1 & 0.7 \\
\hline 258 & 236 & 271 & 196 & 198 & 10 & 2 & n.d. & 167 & 273 & 1 & 9 \\
\hline 4.5 & 4.6 & 4.4 & $3 \cdot 1$ & $3 \cdot 4$ & n.d. & 1.2 & $3 \cdot 3$ & $2 \cdot 8$ & 7.4 & $2 \cdot 3$ & 1.8 \\
\hline $11 \cdot 1$ & 14.9 & 11.4 & $18 \cdot 1$ & 8.7 & n.d. & $17 \cdot 9$ & 8.0 & $6 \cdot 8$ & $18 \cdot 3$ & $8 \cdot 1$ & 13.5 \\
\hline 1.0 & 1.2 & 1.0 & 1.2 & 0.7 & n.d. & 1.3 & $<0.2$ & 0.7 & 1.3 & 0.2 & 1.6 \\
\hline 0.54 & 0.59 & 0.59 & 0.66 & 0.73 & n.d. & 0.48 & n.d. & 0.49 & 0.50 & 0.43 & 0.44 \\
\hline 0.52 & 0.36 & 0.45 & 0.47 & 0.52 & n.d. & 0.30 & n.d. & 0.42 & 0.36 & 0.30 & 0.34 \\
\hline 0.36 & 0.25 & 0.25 & 0.22 & 0.28 & n.d. & 0.05 & n.d. & 0.14 & 0.25 & $0 \cdot 16$ & 0.02 \\
\hline 60 & 77 & 65 & 39 & 59 & n.d. & 10 & n.d. & 23 & 76 & 0 & 30 \\
\hline 3.04 & 1.52 & 1.98 & 1.26 & 1.04 & n.d. & 0.54 & 0.89 & 0.68 & $3 \cdot 29$ & 0.34 & 0.87 \\
\hline $6 \cdot 31$ & 3.43 & 4.25 & $2 \cdot 67$ & $2 \cdot 37$ & n.d. & 1.01 & 1.84 & 1.58 & 7.55 & 0.84 & 1.79 \\
\hline 0.81 & 0.47 & 0.55 & 0.36 & 0.32 & n.d. & 0.13 & 0.31 & 0.23 & 1.04 & 0.12 & 0.21 \\
\hline 3.34 & $2 \cdot 12$ & $2 \cdot 39$ & 1.54 & 1.55 & n.d. & 0.56 & 1.28 & 1.09 & 4.77 & 0.63 & 0.94 \\
\hline 0.85 & 0.60 & 0.61 & 0.35 & 0.42 & n.d. & 0.12 & 0.44 & 0.32 & 1.17 & 0.19 & 0.23 \\
\hline 0.41 & 0.29 & 0.31 & 0.23 & 0.24 & n.d. & 0.05 & 0.22 & 0.20 & 0.46 & 0.06 & 0.07 \\
\hline 0.75 & 0.59 & 0.63 & 0.40 & 0.43 & n.d. & 0.12 & 0.43 & 0.34 & 1.19 & 0.22 & 0.22 \\
\hline 0.12 & 0.11 & 0.11 & 0.07 & 0.08 & n.d. & 0.02 & $<0.1$ & 0.06 & 0.19 & 0.04 & 0.04 \\
\hline 0.76 & 0.75 & 0.73 & 0.49 & 0.55 & n.d. & $0 \cdot 13$ & 0.58 & 0.46 & 1.26 & 0.29 & 0.27 \\
\hline 0.15 & 0.14 & 0.14 & $0 \cdot 10$ & 0.11 & n.d. & 0.03 & 0.12 & 0.09 & 0.24 & 0.06 & 0.05 \\
\hline 0.44 & 0.43 & 0.42 & 0.29 & 0.33 & n.d. & $0 \cdot 10$ & 0.28 & 0.28 & 0.74 & $0 \cdot 16$ & 0.17 \\
\hline 0.07 & 0.07 & 0.07 & 0.05 & 0.05 & n.d. & 0.02 & $<0.1$ & 0.05 & 0.12 & 0.03 & 0.03 \\
\hline 0.44 & 0.42 & 0.43 & 0.29 & 0.34 & n.d. & 0.14 & 0.32 & 0.28 & 0.70 & 0.25 & 0.17 \\
\hline 0.07 & 0.06 & 0.06 & 0.04 & 0.05 & n.d. & 0.02 & $<0.1$ & 0.04 & 0.11 & 0.04 & 0.03 \\
\hline 0.36 & 0.46 & 0.38 & 0.47 & 0.28 & n.d. & 0.48 & $<0.5$ & 0.26 & 0.59 & 0.15 & 0.36 \\
\hline 0.07 & 0.08 & 0.08 & 0.07 & 0.05 & n.d. & 0.09 & $<0.2$ & 0.05 & 0.08 & 0.02 & 0.12 \\
\hline 0.35 & 0.31 & 0.46 & 0.24 & 0.19 & n.d. & 0.40 & $<0.5$ & 0.23 & 0.33 & 0.09 & 0.43 \\
\hline 0.05 & 0.04 & 0.04 & 0.02 & 0.02 & n.d. & 0.06 & $<0.2$ & 0.02 & 0.05 & 0.01 & $0 \cdot 10$ \\
\hline 72 & 65 & 146 & 171 & 81 & n.d. & 331 & & 56 & 312 & 494 & 138 \\
\hline 10 & 81 & 41 & 24 & 16 & 70 & 67 & $<60$ & 20 & 33 & $<20$ & 70 \\
\hline n.d. & 36.9 & $26 \cdot 6$ & $15 \cdot 6$ & $15 \cdot 6$ & n.d. & n.d. & n.d. & n.d. & n.d. & n.d. & n.d. \\
\hline $0 \cdot 10$ & 0.07 & $<0.065$ & $<0.065$ & $<0.065$ & 1.02 & $<0.065$ & $<1$ & $0 \cdot 10$ & $<0.065$ & 1.47 & $60 \cdot 78$ \\
\hline 1.30 & $1 \cdot 10$ & 1.37 & 0.18 & 0.06 & 10.92 & 0.04 & 0.23 & 1.06 & 0.04 & 1.67 & 118.88 \\
\hline 0.41 & $0 \cdot 19$ & $0 \cdot 18$ & $<0.12$ & $<0.12$ & 3.40 & $<0.12$ & $<2$ & 0.32 & 0.12 & 4.99 & 110.53 \\
\hline 3.30 & 4.94 & $3 \cdot 16$ & 0.23 & 0.16 & 21.87 & 0.08 & $<1$ & $2 \cdot 18$ & $<0.082$ & 1.34 & 389.70 \\
\hline $11 \cdot 2$ & $27 \cdot 6$ & 43.5 & 11.6 & $3 \cdot 2$ & 31.9 & 0.6 & $2 \cdot 2$ & $7 \cdot 8$ & 1.6 & 9.9 & $2087 \cdot 1$ \\
\hline $12 \cdot 0$ & $24 \cdot 1$ & 17.9 & $6 \cdot 3$ & $9 \cdot 4$ & 9.0 & $1 \cdot 1$ & $3 \cdot 6$ & $9 \cdot 3$ & 0.3 & $26 \cdot 1$ & 940.0 \\
\hline 0.93 & 0.22 & 0.67 & 0.05 & $<0.484$ & 1.46 & $<0.484$ & 0.89 & 0.83 & 0.49 & $<0.484$ & 42.58 \\
\hline$-3 \cdot 1$ & n.d. & n.d. & n.d. & n.d. & n.d. & n.d. & n.d. & n.d. & n.d. & n.d. & 1 \\
\hline
\end{tabular}


Table 3: Continued

\begin{tabular}{|c|c|c|c|c|c|c|c|c|c|c|c|}
\hline $\begin{array}{l}\text { Sompuj } \\
\text { SiKi2- } \\
167.66 \\
551 \\
\text { drillcore } \\
\text { Ol-opx } \\
\text { IV }\end{array}$ & $\begin{array}{c}\text { Sompuj } \\
\text { SiKi2- } \\
176 \cdot 0 \\
559 \\
\text { drillcore } \\
\text { Ol-opx } \\
\text { IV }\end{array}$ & $\begin{array}{c}\text { Sompuj } \\
\text { SIKI2- } \\
178.65 \\
561.9 \\
\text { drillcore } \\
\text { OI-opx } \\
\text { IV }\end{array}$ & $\begin{array}{c}\text { Sompuj } \\
\text { SiKi2- } \\
180 \cdot 75 \\
564 \\
\text { drillcore } \\
\text { Webs } \\
\text { IV }\end{array}$ & $\begin{array}{c}627 \\
\text { Outcrop } \\
\text { GN } \\
\text { IV }\end{array}$ & $\begin{array}{c}631 \\
\text { Outcrop } \\
\text { Anorth } \\
\text { IV }\end{array}$ & $\begin{array}{c}631 \\
\text { Outcrop } \\
\text { Anorth } \\
\text { IV }\end{array}$ & $\begin{array}{c}631.5 \\
\text { Outcrop } \\
\text { Webs } \\
\text { IV }\end{array}$ & $\begin{array}{c}649 \\
\text { Outcrop } \\
\text { GN } \\
\text { IV }\end{array}$ & $\begin{array}{c}651 \\
\text { Outcrop } \\
\text { Anorth } \\
\text { IV }\end{array}$ & $\begin{array}{c}654 \\
\text { Outcrop } \\
\text { GN } \\
\text { IV }\end{array}$ & $\begin{array}{c}760 \\
\text { Outcrop } \\
\text { GN } \\
\text { IV }\end{array}$ \\
\hline $40 \cdot 40$ & $46 \cdot 50$ & 37.30 & 50.62 & 49.79 & 50.42 & $49 \cdot 13$ & 43.50 & 49.80 & 48.43 & 51.00 & 50.79 \\
\hline $0 \cdot 13$ & 0.14 & 0.07 & 0.27 & 0.21 & 0.12 & 0.28 & 0.11 & 0.21 & 0.15 & 0.44 & 0.24 \\
\hline $5 \cdot 21$ & $4 \cdot 36$ & 4.47 & 2.91 & 17.04 & 25.02 & 24.58 & 4.95 & $21 \cdot 10$ & 23.62 & 15.80 & 16.61 \\
\hline 14.51 & 11.23 & $19 \cdot 18$ & 8.02 & 7.31 & 3.67 & 4.99 & $19 \cdot 22$ & 6.06 & 4.70 & 7.97 & 6.58 \\
\hline 0.14 & 0.16 & 0.13 & 0.20 & 0.12 & 0.08 & 0.08 & 0.16 & 0.08 & 0.08 & 0.13 & 0.14 \\
\hline 27.02 & 23.30 & $26 \cdot 82$ & 23.08 & $10 \cdot 60$ & $2 \cdot 31$ & 5.65 & 19.97 & 7.50 & 3.99 & 8.88 & 9.46 \\
\hline 1.66 & 2.83 & 1.97 & 8.89 & $10 \cdot 43$ & 13.04 & $9 \cdot 22$ & 8.09 & $12 \cdot 72$ & 13.77 & 12.61 & 12.60 \\
\hline 0.09 & 0.04 & 0.10 & 0.11 & 1.85 & 3.06 & 2.55 & 0.11 & 1.99 & 2.89 & 1.90 & 1.84 \\
\hline 0.01 & 0.02 & 0.00 & 0.00 & 0.16 & 1.54 & 1.99 & 0.00 & 0.21 & 0.36 & 0.20 & 0.19 \\
\hline 0.02 & 0.01 & 0.01 & 0.01 & 0.02 & 0.01 & 0.01 & 0.01 & 0.02 & 0.02 & 0.03 & 0.01 \\
\hline 0.05 & n.d. & 0.05 & 0.15 & 0.02 & 0.02 & 0.01 & 0.02 & n.d. & 0.03 & n.d. & 0.06 \\
\hline $10 \cdot 16$ & 11.46 & 8.94 & 4.78 & 1.67 & 1.99 & 2.78 & 2.98 & n.d. & 1.90 & n.d. & 0.91 \\
\hline $99 \cdot 38$ & 100.07 & 99.04 & 99.06 & $99 \cdot 23$ & 101.29 & $101 \cdot 26$ & $99 \cdot 13$ & 99.69 & 99.93 & 98.97 & 99.43 \\
\hline 16 & 16 & 15 & 30 & 17 & 8 & 6 & 18 & 20 & 14 & 42 & 30 \\
\hline 48 & 43 & 40 & 45 & 70 & 38 & 31 & 47 & 94 & 64 & 204 & 101 \\
\hline 320 & 472 & 369 & 1037 & 153 & 118 & 44 & 127 & 204 & 191 & 665 & 418 \\
\hline 141 & 111 & 163 & 98 & 61 & 29 & 62 & 94 & 39 & 39 & 43 & 55 \\
\hline 1195 & 1245 & 1033 & 667 & 301 & 32 & 196 & 601 & 251 & 62 & 218 & 148 \\
\hline 35 & 25 & 152 & 1285 & 180 & 162 & 75 & 107 & 48 & 56 & 61 & 83 \\
\hline 50 & 49 & 40 & 21 & 28 & 24 & 27 & 29 & n.d. & 40 & n.d. & 82 \\
\hline 5.4 & $4 \cdot 1$ & $5 \cdot 1$ & 3.2 & 13.5 & $19 \cdot 7$ & $18 \cdot 3$ & $5 \cdot 3$ & n.d. & $16 \cdot 3$ & n.d. & 12.9 \\
\hline 0.2 & 0.4 & 0.2 & 0.2 & $3 \cdot 2$ & $45 \cdot 7$ & $56 \cdot 3$ & 0.0 & $4 \cdot 1$ & 11.1 & 4.3 & 3.8 \\
\hline 7 & 13 & 9 & 7 & 257 & 727 & 436 & 4 & n.d. & 367 & n.d. & 247 \\
\hline 3.0 & $2 \cdot 6$ & 2.5 & $3 \cdot 1$ & 5.0 & 3.0 & $2 \cdot 0$ & $2 \cdot 3$ & 4.5 & 8.6 & 11.8 & $5 \cdot 8$ \\
\hline $15 \cdot 8$ & 5.7 & 11.0 & 28.5 & 13.7 & 11.8 & $10 \cdot 2$ & 6.0 & 15.4 & 10.5 & 28.5 & $15 \cdot 6$ \\
\hline 1.0 & 0.5 & 0.7 & 1.2 & 2.0 & 1.1 & 1.4 & 0.8 & 0.4 & 0.8 & 1.1 & 1.0 \\
\hline 0.47 & 0.46 & 0.52 & 0.46 & 0.57 & 0.57 & 0.59 & 0.47 & n.d. & 0.51 & n.d. & 0.51 \\
\hline 0.31 & 1.25 & 0.27 & 0.25 & 0.32 & 0.44 & 0.40 & 0.16 & n.d. & 0.16 & n.d. & 0.30 \\
\hline 0.04 & 0.22 & 0.03 & 0.03 & 0.57 & 0.99 & 3.23 & 0.01 & n.d. & 0.81 & n.d. & 0.41 \\
\hline 7 & 8 & 3 & 1 & 85 & 227 & 362 & 12 & n.d. & 100 & n.d. & 76 \\
\hline 1.18 & 1.51 & 0.84 & 0.57 & 3.04 & $4 \cdot 18$ & 3.60 & 0.57 & 3.03 & 7.80 & 4.65 & 2.58 \\
\hline 2.60 & 2.84 & 1.82 & 1.48 & $6 \cdot 37$ & 7.80 & 6.59 & 1.17 & 6.25 & 16.80 & 11.60 & 5.63 \\
\hline 0.33 & 0.34 & 0.23 & 0.21 & 0.78 & 0.86 & 0.72 & 0.24 & 0.71 & $2 \cdot 14$ & 1.59 & 0.75 \\
\hline 1.38 & 1.39 & 0.94 & 1.00 & 3.31 & 3.39 & 2.73 & 1.05 & $3 \cdot 15$ & 9.00 & 7.33 & 3.30 \\
\hline 0.34 & 0.32 & 0.24 & 0.29 & 0.75 & 0.64 & 0.44 & 0.27 & 0.71 & 2.08 & 1.92 & 0.81 \\
\hline 0.06 & 0.09 & 0.06 & 0.06 & 0.44 & 0.87 & 0.60 & 0.08 & 0.46 & 1.14 & 0.47 & 0.39 \\
\hline 0.32 & 0.28 & 0.24 & 0.34 & 0.76 & 0.62 & 0.43 & 0.24 & 0.82 & 1.97 & 2.39 & 0.81 \\
\hline 0.06 & 0.05 & 0.05 & 0.06 & 0.13 & 0.09 & 0.06 & 0.05 & 0.12 & 0.30 & 0.34 & 0.14 \\
\hline 0.43 & 0.32 & 0.32 & 0.45 & 0.81 & 0.54 & 0.34 & 0.31 & 0.82 & 1.65 & $2 \cdot 19$ & 0.95 \\
\hline 0.08 & 0.07 & 0.06 & 0.09 & 0.16 & $0 \cdot 10$ & 0.07 & 0.06 & 0.19 & 0.28 & 0.46 & 0.19 \\
\hline 0.28 & 0.18 & 0.20 & 0.30 & 0.47 & 0.30 & 0.20 & 0.20 & 0.46 & 0.75 & 1.25 & 0.58 \\
\hline 0.05 & 0.03 & 0.04 & 0.05 & 0.08 & 0.05 & 0.03 & 0.04 & $<0.1$ & 0.10 & 0.18 & 0.10 \\
\hline 0.28 & 0.24 & 0.23 & 0.30 & 0.50 & 0.28 & 0.20 & 0.25 & 0.52 & 0.57 & 1.15 & 0.58 \\
\hline 0.05 & 0.03 & 0.03 & 0.05 & 0.07 & 0.04 & 0.03 & 0.04 & $<0.1$ & 0.08 & 0.18 & 0.08 \\
\hline 0.39 & 0.11 & 0.31 & 0.68 & 0.45 & 0.36 & 0.33 & 0.23 & 0.50 & 0.37 & 0.94 & 0.49 \\
\hline 0.07 & 0.04 & 0.04 & 0.07 & 0.13 & 0.09 & 0.09 & 0.04 & $<0.2$ & 0.06 & $<0.2$ & 0.06 \\
\hline 0.35 & 0.12 & 0.32 & 0.33 & 0.32 & 0.32 & 0.25 & 0.34 & $<0.5$ & 0.47 & $<0.5$ & 0.39 \\
\hline 0.07 & 0.02 & 0.05 & 0.05 & 0.07 & 0.05 & 0.03 & 0.04 & $<0.2$ & 0.33 & $<0.2$ & 0.07 \\
\hline 7243 & 39 & 7415 & 5223 & 74 & 493 & 265 & 140 & 150 & 376 & 370 & 118 \\
\hline 763 & 654 & 2121 & 2086 & 104 & 58 & 64 & 239 & 148 & 54 & 368 & 105 \\
\hline n.d. & n.d. & n.d. & n.d. & n.d. & n.d. & n.d. & n.d. & n.d. & n.d. & n.d. & n.d. \\
\hline $2 \cdot 12$ & $6 \cdot 34$ & $6 \cdot 37$ & $9 \cdot 80$ & 0.37 & 0.17 & 0.09 & $<0.065$ & $<1$ & 0.08 & $<1$ & $<0.065$ \\
\hline 1.49 & 6.96 & $10 \cdot 49$ & $16 \cdot 48$ & 0.13 & 0.15 & 0.11 & 0.38 & $<0.1$ & 0.20 & $<0.1$ & 0.07 \\
\hline 5.18 & $18 \cdot 40$ & $15 \cdot 32$ & 36.40 & 0.18 & $<0.12$ & 0.14 & 0.15 & $<2$ & 0.16 & $<2$ & 0.16 \\
\hline 0.81 & 8.43 & 27.82 & 19.34 & 0.13 & 0.21 & 0.09 & 0.63 & $<1$ & 0.36 & $<1$ & 0.08 \\
\hline 4.5 & $19 \cdot 2$ & 102.5 & 82.0 & $7 \cdot 1$ & $6 \cdot 1$ & 5.4 & 4.6 & 3.9 & $4 \cdot 2$ & $4 \cdot 3$ & $2 \cdot 1$ \\
\hline $7 \cdot 8$ & $20 \cdot 1$ & 77.8 & $116 \cdot 3$ & 13.6 & 9.5 & $6 \cdot 8$ & 1.6 & $5 \cdot 1$ & 2.7 & $4 \cdot 3$ & 2.0 \\
\hline 1.53 & $<0.484$ & 4.47 & 5.92 & 1.93 & 0.58 & $<0.484$ & 1.86 & 1.26 & $<0.484$ & 1.51 & 0.78 \\
\hline n.d. & n.d. & n.d. & n.d. & n.d. & n.d. & n.d. & n.d. & n.d. & n.d. & n.d. & -1.3 \\
\hline
\end{tabular}


Table 3: Continued

\begin{tabular}{|c|c|c|c|c|c|c|c|c|c|c|c|}
\hline Ala-Pen & Ala-Pen & Ala-Pen & Ala-Pen & Ala-Pen & Ala-Pen & Ala-Pen & Ala-Pen & Ala-Pen & Ala-Pen & Ala-Pen & Ala-Pen \\
\hline 29 PEN & 2 PEN & 9 PEN & 30 PEN & 55 PAT & 31 PEN & 32 PEN & 33 PEN & 64 PAT & 67 PAT & 68 РАТ & 74 PAT \\
\hline 796 & 802 & 803 & 804 & 846 & 885 & 913 & 1100 & 1158 & 1220 & 1240 & 1440 \\
\hline Outcrop & Outcrop & Outcrop & Outcrop & Outcrop & Outcrop & Outcrop & Outcrop & Outcrop & Outcrop & Outcrop & Outcrop \\
\hline GN & GN & Anorth & GN & GN & GN & GN & GN & GN & GN & GN & GN \\
\hline IV & IV & IV & IV & IV & IV & IV & IV & IV & IV & IV & IV \\
\hline 51.09 & $46 \cdot 60$ & $52 \cdot 20$ & 49.94 & $50 \cdot 86$ & $50 \cdot 72$ & 51.42 & 51.50 & 51.79 & 50.59 & 51.93 & $51 \cdot 16$ \\
\hline 0.27 & 0.20 & 0.15 & 0.21 & 0.31 & 0.24 & 0.26 & 0.23 & 0.31 & 0.23 & 0.22 & 0.25 \\
\hline $19 \cdot 22$ & $16 \cdot 20$ & 25.80 & 18.63 & $15 \cdot 69$ & 17.93 & 16.02 & $16 \cdot 62$ & $17 \cdot 78$ & $17 \cdot 16$ & 21.43 & $17 \cdot 46$ \\
\hline 5.77 & 8.55 & 2.79 & 6.90 & 7.09 & $6 \cdot 26$ & 6.54 & $6 \cdot 20$ & $5 \cdot 87$ & $6 \cdot 61$ & 4.83 & 6.64 \\
\hline 0.10 & $0 \cdot 10$ & 0.03 & 0.13 & 0.13 & 0.13 & 0.13 & 0.12 & 0.12 & 0.13 & 0.09 & 0.13 \\
\hline $6 \cdot 81$ & 8.69 & 2.53 & 8.07 & 9.45 & $8 \cdot 39$ & 8.67 & 8.51 & $8 \cdot 12$ & 8.90 & $5 \cdot 42$ & 7.93 \\
\hline $14 \cdot 66$ & 11.96 & 11.80 & 11.55 & $12 \cdot 75$ & 12.56 & 12.92 & 13.51 & 13.75 & 12.64 & $13 \cdot 27$ & 12.68 \\
\hline $2 \cdot 15$ & 1.80 & 4.07 & 2.02 & 1.63 & 2.08 & 1.77 & 1.76 & 1.96 & 1.89 & 2.58 & $2 \cdot 11$ \\
\hline 0.22 & 0.22 & 0.41 & 0.30 & 0.14 & 0.20 & 0.23 & 0.21 & 0.17 & 0.42 & 0.33 & 0.20 \\
\hline 0.01 & $<0.01$ & $<0.01$ & 0.01 & 0.02 & 0.01 & 0.02 & 0.01 & 0.01 & 0.01 & 0.02 & 0.02 \\
\hline 0.07 & n.d. & n.d. & 0.02 & 0.06 & 0.04 & 0.04 & 0.02 & 0.02 & 0.01 & 0.01 & 0.01 \\
\hline 0.74 & n.d. & n.d. & 1.54 & 1.11 & 1.03 & 1.11 & 0.79 & 0.74 & 1.55 & 1.06 & 1.54 \\
\hline $101 \cdot 12$ & 94.31 & 99.78 & $99 \cdot 32$ & 99.25 & 99.60 & 99.13 & 99.49 & $100 \cdot 65$ & $100 \cdot 16$ & $101 \cdot 19$ & $100 \cdot 14$ \\
\hline 31 & 30 & 11 & 20 & 34 & 27 & 30 & 36 & 37 & 33 & 24 & 34 \\
\hline 115 & 120 & 53 & 72 & 120 & 93 & 110 & 129 & 120 & 108 & 84 & 103 \\
\hline 455 & 490 & 28 & 145 & 442 & 276 & 293 & 116 & 103 & 82 & 58 & 71 \\
\hline 35 & 115 & 11 & 47 & 81 & 53 & 55 & 40 & 41 & 38 & 27 & 39 \\
\hline 102 & 4300 & 119 & 210 & 144 & 133 & 303 & 131 & 146 & 130 & 88 & 132 \\
\hline 82 & 8000 & 40 & 100 & 133 & 97 & 73 & 138 & 88 & 28 & 110 & 92 \\
\hline 70 & n.d. & n.d. & 36 & 48 & 52 & 80 & 47 & 39 & 48 & 30 & 37 \\
\hline $14 \cdot 3$ & n.d. & n.d. & $14 \cdot 3$ & $12 \cdot 0$ & $13 \cdot 0$ & $12 \cdot 8$ & $13 \cdot 3$ & 13.5 & $13 \cdot 6$ & $15 \cdot 6$ & 13.9 \\
\hline 3.5 & $5 \cdot 4$ & $9 \cdot 4$ & $6 \cdot 3$ & 2.7 & 3.7 & $5 \cdot 1$ & $5 \cdot 1$ & $5 \cdot 3$ & $18 \cdot 1$ & 8.8 & 4. 1 \\
\hline 308 & n.d. & n.d. & 277 & 226 & 256 & 252 & 269 & 285 & 283 & 353 & 298 \\
\hline $7 \cdot 1$ & $5 \cdot 1$ & 1.9 & $4 \cdot 7$ & $7 \cdot 8$ & $5 \cdot 2$ & 6.4 & $6 \cdot 3$ & $6 \cdot 3$ & $6 \cdot 0$ & 5.0 & 6.4 \\
\hline $15 \cdot 7$ & 11.4 & 13.5 & $10 \cdot 4$ & $22 \cdot 1$ & $16 \cdot 1$ & 17.9 & 14.4 & 20.6 & $15 \cdot 6$ & $17 \cdot 7$ & 17.5 \\
\hline 0.7 & $<0.2$ & 0.2 & 1.0 & 1.5 & 1.4 & 1.1 & 1.0 & 1.9 & 1.1 & 1.6 & 1.1 \\
\hline 0.51 & n.d. & n.d. & 0.49 & 0.64 & 0.60 & 0.48 & 0.50 & 0.52 & 0.46 & 0.52 & 0.53 \\
\hline 0.36 & n.d. & n.d. & 0.31 & 0.42 & 0.36 & 0.35 & 0.51 & 1.06 & 0.36 & 0.39 & 0.41 \\
\hline 0.28 & n.d. & n.d. & 0.69 & 0.25 & 0.53 & 0.34 & 0.25 & 0.26 & 0.48 & 0.16 & 0.22 \\
\hline 82 & n.d. & n.d. & 104 & 81 & 83 & 82 & 66 & 66 & 82 & 115 & 68 \\
\hline $3 \cdot 16$ & 1.74 & $2 \cdot 86$ & $2 \cdot 15$ & 3.50 & 2.87 & 3.02 & $2 \cdot 24$ & $2 \cdot 41$ & 2.62 & 3.09 & 3.23 \\
\hline $7 \cdot 40$ & $4 \cdot 36$ & $5 \cdot 39$ & 4.51 & $7 \cdot 81$ & $6 \cdot 11$ & 6.75 & $5 \cdot 10$ & 5.45 & 5.82 & 6.58 & 6.93 \\
\hline 1.03 & 0.56 & 0.61 & 0.59 & 1.04 & 0.76 & 0.89 & 0.68 & 0.74 & 0.77 & 0.82 & 0.89 \\
\hline 4.63 & $3 \cdot 22$ & $2 \cdot 10$ & 2.50 & 4.69 & $3 \cdot 22$ & 3.83 & $3 \cdot 28$ & $3 \cdot 28$ & $3 \cdot 36$ & $3 \cdot 33$ & $3 \cdot 80$ \\
\hline 1.15 & 0.64 & 0.39 & 0.62 & 1.12 & 0.77 & 0.98 & 0.87 & 0.89 & 0.87 & 0.78 & 0.96 \\
\hline 0.47 & 0.34 & 0.51 & 0.40 & 0.45 & 0.38 & 0.40 & 0.40 & 0.42 & 0.42 & 0.46 & 0.44 \\
\hline 1.11 & 0.81 & 0.34 & 0.65 & 1.11 & 0.78 & 0.95 & 0.88 & 0.89 & 0.88 & 0.79 & 0.95 \\
\hline 0.19 & 0.13 & $<0.1$ & 0.11 & 0.18 & 0.13 & 0.16 & 0.15 & 0.16 & 0.15 & 0.13 & 0.17 \\
\hline 1.23 & 0.74 & 0.20 & 0.75 & 1.20 & 0.83 & 1.04 & 1.06 & 1.03 & 0.96 & 0.80 & 1.01 \\
\hline 0.23 & 0.19 & $<0.1$ & 0.15 & 0.23 & 0.16 & 0.20 & 0.20 & 0.21 & $0 \cdot 19$ & 0.17 & 0.22 \\
\hline 0.69 & 0.49 & 0.20 & 0.47 & 0.74 & 0.51 & 0.61 & 0.62 & 0.61 & 0.60 & 0.48 & 0.62 \\
\hline 0.11 & $<0.1$ & $<0.1$ & 0.08 & 0.12 & 0.08 & 0.10 & 0.10 & 0.11 & 0.10 & 0.08 & 0.10 \\
\hline 0.67 & 0.47 & $<0.15$ & 0.50 & 0.69 & 0.55 & 0.63 & 0.58 & 0.62 & 0.61 & 0.48 & 0.62 \\
\hline 0.10 & $<0.1$ & $<0.1$ & 0.08 & 0.11 & 0.08 & 0.09 & 0.09 & 0.10 & 0.10 & 0.08 & 0.09 \\
\hline 0.51 & $<0.5$ & $<0.5$ & 0.36 & 0.64 & 0.48 & 0.57 & 0.47 & 0.62 & 0.48 & 0.52 & 0.53 \\
\hline 0.05 & $<0.2$ & $<0.2$ & 0.07 & $0 \cdot 10$ & $0 \cdot 10$ & 0.08 & 0.07 & 0.11 & 0.07 & 0.11 & 0.06 \\
\hline 0.32 & $<0.5$ & $<0.5$ & 0.30 & 0.56 & 0.46 & 0.48 & 0.33 & 0.38 & 0.38 & 0.45 & 0.50 \\
\hline 0.05 & $<0.2$ & $<0.2$ & 0.03 & 0.08 & 0.08 & 0.08 & 0.06 & 0.06 & 0.07 & 0.13 & 0.09 \\
\hline 242 & 14600 & $<100$ & 114 & 318 & 97 & 113 & 127 & 162 & 304 & 277 & 265 \\
\hline 43 & 14600 & $<60$ & 87 & 84 & 235 & 173 & 84 & 91 & 140 & 68 & 161 \\
\hline n.d. & n.d. & n.d. & n.d. & n.d. & $79 \cdot 3$ & n.d. & n.d. & n.d. & n.d. & n.d. & n.d. \\
\hline$<0.065$ & 74.60 & 3.68 & 0.25 & $<0.065$ & $<0.065$ & $<0.065$ & $<0.065$ & $<0.065$ & $<0.065$ & $<0.065$ & $<0.065$ \\
\hline 0.04 & 137.00 & 0.69 & 0.26 & 0.13 & 0.09 & 0.04 & 0.04 & 0.03 & 1.88 & 2.72 & 0.66 \\
\hline$<0.12$ & $80 \cdot 20$ & $<2$ & 0.33 & $<0.12$ & 0.19 & $<0.12$ & 0.14 & 0.13 & 0.14 & 0.15 & 0.16 \\
\hline$<0.082$ & 510.00 & $<1$ & 0.19 & 0.11 & 0.12 & $<0.082$ & $<0.082$ & $<0.082$ & 0.33 & 0.25 & 1.02 \\
\hline 1.9 & $5550 \cdot 0$ & 12.9 & $7 \cdot 3$ & 5.9 & $3 \cdot 2$ & 1.7 & 1.9 & 1.6 & 137.5 & 219.0 & 27.9 \\
\hline$<0.471$ & $21000 \cdot 0$ & 1.2 & 7.6 & $4 \cdot 6$ & $1 \cdot 1$ & $1 \cdot 3$ & $2 \cdot 4$ & $1 \cdot 3$ & $126 \cdot 4$ & 31.1 & $30 \cdot 1$ \\
\hline$<0.484$ & $1010 \cdot 00$ & 0.91 & 1.07 & 0.62 & 0.61 & 0.72 & 0.73 & $1 \cdot 10$ & 3.07 & 5.55 & 16.96 \\
\hline n.d. & n.d. & n.d. & n.d. & n.d. & n.d. & n.d. & -1.4 & n.d. & n.d. & n.d. & n.d. \\
\hline
\end{tabular}


Table 3: Continued

\begin{tabular}{|c|c|c|c|c|c|c|c|c|c|}
\hline $\begin{array}{l}\text { Ala-Pen } \\
34 \text { PEN } \\
1490 \\
\text { Outcrop } \\
\text { GN } \\
\text { IV }\end{array}$ & $\begin{array}{c}\text { Ala-Pen } \\
35 \text { PEN } \\
1510 \\
\text { Outcrop } \\
\text { GN } \\
\text { IV }\end{array}$ & $\begin{array}{c}\text { Ala-Pen } \\
3 \text { Pen } \\
1530 \\
\text { Outcrop } \\
\text { Anorth } \\
\text { IV }\end{array}$ & $\begin{array}{c}\text { Ala-Pen } \\
36 \text { PEN } \\
1535 \\
\text { Outcrop } \\
\text { Webs } \\
\text { V }\end{array}$ & $\begin{array}{c}\text { Ala-Pen } \\
4 \text { Pen } \\
1540 \\
\text { Outcrop } \\
\text { Norite } \\
\text { V }\end{array}$ & $\begin{array}{c}\text { Ala-Pen } \\
83 \text { PAT } \\
1620 \\
\text { Outcrop } \\
\text { Norite } \\
\text { V }\end{array}$ & $\begin{array}{c}\text { Ala-Pen } \\
37 \text { PEN } \\
1670 \\
\text { Outcrop } \\
\text { GN } \\
\text { V }\end{array}$ & $\begin{array}{c}\text { Ala-Pen } \\
38 \text { PEN } \\
1795 \\
\text { Outcrop } \\
\text { GN } \\
\text { V }\end{array}$ & $\begin{array}{c}\text { Ala-Pen } \\
39 \text { PEN } \\
1920 \\
\text { Outcrop } \\
\text { Gabbro } \\
\text { V }\end{array}$ & $\begin{array}{c}\text { Ala-Pen } \\
97 \text { PAT } \\
2260 \\
\text { Outcrop } \\
\text { Gabbro } \\
\text { V }\end{array}$ \\
\hline 49.86 & 53.58 & $47 \cdot 10$ & 51.00 & $50 \cdot 30$ & $51 \cdot 16$ & $52 \cdot 42$ & 51.88 & 51.97 & 53.43 \\
\hline 0.20 & 0.83 & 0.19 & 0.37 & 0.20 & 0.31 & 0.26 & 0.25 & 0.22 & 0.40 \\
\hline $17 \cdot 84$ & 21.06 & 23.70 & $6 \cdot 74$ & $19 \cdot 10$ & 16.97 & 18.06 & $18 \cdot 40$ & $17 \cdot 73$ & $15 \cdot 39$ \\
\hline $6 \cdot 83$ & 4.49 & 7.07 & 12.55 & 6.54 & $8 \cdot 18$ & 7.09 & $6 \cdot 14$ & 6.90 & 8.40 \\
\hline 0.13 & 0.07 & 0.05 & 0.22 & $0 \cdot 12$ & $0 \cdot 14$ & $0 \cdot 13$ & 0.11 & $0 \cdot 13$ & $0 \cdot 17$ \\
\hline 8.23 & $4 \cdot 18$ & 4.60 & 17.68 & $9 \cdot 16$ & $9 \cdot 17$ & 8.22 & 8.07 & 9.04 & 8.29 \\
\hline 13.06 & 10.95 & $10 \cdot 27$ & 7.97 & $9 \cdot 62$ & 8.95 & 8.91 & $10 \cdot 12$ & 9.43 & 7.92 \\
\hline 2.23 & 2.39 & 2.25 & 0.12 & $2 \cdot 25$ & $2 \cdot 39$ & $2 \cdot 20$ & 2.43 & 2.06 & $3 \cdot 20$ \\
\hline 0.17 & 0.39 & 0.59 & 0.04 & $0 \cdot 19$ & 0.55 & 0.53 & 0.34 & 0.44 & 0.80 \\
\hline 0.01 & $0 \cdot 10$ & 0.03 & 0.05 & 0.02 & 0.02 & 0.03 & 0.04 & 0.02 & 0.06 \\
\hline 0.01 & 0.01 & n.d. & 0.15 & n.d. & n.d. & 0.05 & 0.04 & 0.05 & 0.05 \\
\hline 1.44 & 1.94 & n.d. & 3.47 & n.d. & 1.19 & 1.35 & 1.38 & 1.86 & 1.91 \\
\hline $100 \cdot 02$ & 99.98 & 95.86 & $100 \cdot 36$ & 97.50 & 99.03 & $99 \cdot 25$ & $99 \cdot 19$ & 99.83 & $100 \cdot 02$ \\
\hline 32 & 10 & 12 & 35 & 17 & 21 & 19 & 20 & 21 & 33 \\
\hline 111 & 103 & 68 & 144 & 78 & 89 & 84 & 90 & 99 & 152 \\
\hline 58 & 74 & 160 & 1042 & 480 & 436 & 364 & 298 & 350 & 350 \\
\hline 59 & 33 & 79 & 90 & 37 & 52 & 55 & 43 & 53 & 47 \\
\hline 139 & 112 & 3600 & 343 & 240 & 186 & 163 & 134 & 139 & 118 \\
\hline 152 & 175 & 3760 & 61 & 40 & 59 & 69 & 116 & 60 & 101 \\
\hline 55 & 57 & n.d. & 67 & n.d. & 53 & 62 & 56 & 38 & 72 \\
\hline $13 \cdot 8$ & 17.0 & n.d. & 7.8 & n.d. & $15 \cdot 1$ & $15 \cdot 3$ & $15 \cdot 5$ & 14.4 & $15 \cdot 9$ \\
\hline 4.8 & $11 \cdot 1$ & $17 \cdot 9$ & 0.6 & 4.9 & $16 \cdot 3$ & $16 \cdot 0$ & 9.5 & $12 \cdot 0$ & $31 \cdot 1$ \\
\hline 344 & 371 & n.d. & 8 & n.d. & 311 & 343 & 339 & 321 & 295 \\
\hline $6 \cdot 3$ & 8.5 & $4 \cdot 2$ & 9.9 & 3.9 & $7 \cdot 2$ & 6.4 & $6 \cdot 1$ & 4.9 & $11 \cdot 2$ \\
\hline 18.0 & 55.6 & 24.3 & 34.3 & 14.8 & $35 . \overline{5}$ & 28.8 & $26 \cdot 0$ & $22 \cdot 1$ & 46.0 \\
\hline 0.9 & 4.8 & 0.5 & $2 \cdot 4$ & 0.5 & $2 \cdot 1$ & 2.9 & 1.5 & $1 \cdot 1$ & $2 \cdot 3$ \\
\hline 0.57 & 0.66 & n.d. & 0.52 & n.d. & 0.51 & 0.79 & 0.59 & 0.72 & 0.55 \\
\hline 0.30 & 0.58 & n.d. & 0.39 & n.d. & 0.42 & 0.46 & 0.52 & 0.27 & 0.59 \\
\hline 0.30 & 0.28 & n.d. & 0.04 & n.d. & 0.96 & 0.85 & 0.54 & 0.86 & 0.59 \\
\hline 47 & 143 & n.d. & 5 & n.d. & 152 & 155 & 112 & 126 & 210 \\
\hline 2.94 & 8.81 & $4 \cdot 11$ & 2.89 & $2 \cdot 70$ & $5 \cdot 39$ & $5 \cdot 35$ & 4.58 & $3 \cdot 60$ & $7 \cdot 10$ \\
\hline 6.54 & 18.57 & $6 \cdot 81$ & 6.77 & 5.45 & $11 \cdot 10$ & 11.18 & 9.64 & 7.47 & 16.04 \\
\hline 0.87 & $2 \cdot 18$ & 0.78 & 1.05 & 0.63 & 1.33 & 1.33 & $1 \cdot 18$ & 0.89 & 2.03 \\
\hline 3.85 & $8 \cdot 84$ & 3.41 & 5.28 & $3 \cdot 17$ & $5 \cdot 19$ & 5.45 & 4.84 & 3.65 & $8 \cdot 30$ \\
\hline 0.96 & 1.68 & 0.70 & 1.32 & 0.43 & 1.13 & 1.09 & 1.00 & 0.77 & 1.95 \\
\hline 0.45 & 0.63 & 0.39 & 0.32 & 0.32 & 0.53 & 0.53 & 0.46 & 0.46 & 0.71 \\
\hline 0.93 & 1.63 & 0.64 & 1.33 & 0.51 & 1.05 & 1.08 & 0.97 & 0.75 & 1.86 \\
\hline 0.16 & 0.24 & 0.12 & 0.21 & $0 \cdot 10$ & 0.17 & $0 \cdot 16$ & 0.15 & 0.12 & 0.30 \\
\hline 1.06 & 1.44 & 0.74 & 1.41 & 0.67 & 1.05 & 1.06 & 0.94 & 0.78 & 1.79 \\
\hline 0.21 & 0.27 & 0.16 & 0.28 & 0.14 & 0.22 & 0.20 & $0 \cdot 19$ & 0.15 & 0.36 \\
\hline 0.63 & 0.86 & 0.42 & 0.91 & 0.30 & 0.72 & 0.64 & 0.60 & 0.49 & 1.05 \\
\hline 0.10 & 0.13 & $<0.1$ & 0.16 & $<0.1$ & 0.12 & 0.11 & $0 \cdot 10$ & 0.08 & 0.17 \\
\hline 0.61 & 0.78 & 0.45 & 0.97 & 0.49 & 0.70 & 0.65 & 0.57 & 0.53 & 1.03 \\
\hline 0.09 & 0.12 & $<0.1$ & 0.15 & $<0.1$ & 0.12 & $0 \cdot 10$ & 0.09 & 0.07 & 0.16 \\
\hline 0.56 & 1.53 & 0.70 & 0.89 & 0.50 & 0.95 & 0.82 & 0.74 & 0.61 & $1 \cdot 18$ \\
\hline 0.06 & 0.29 & $<0.2$ & 0.16 & $<0.2$ & 0.12 & 0.20 & 0.12 & 0.09 & 0.16 \\
\hline 0.46 & 1.44 & $<0.5$ & 0.86 & $<0.5$ & 1.09 & 0.88 & 0.88 & 0.62 & 1.61 \\
\hline 0.07 & 0.31 & $<0.2$ & 0.14 & $<0.2$ & 0.19 & 0.19 & 0.17 & 0.12 & 0.29 \\
\hline 270 & 405 & 9900 & 206 & 110 & 304 & 334 & 125 & 124 & 613 \\
\hline 100 & 143 & 9900 & 154 & 110 & 93 & 154 & 136 & 118 & 166 \\
\hline 34.5 & n.d. & 24600 & $12 \cdot 8$ & n.d. & n.d. & n.d. & n.d. & $16 \cdot 4$ & n.d. \\
\hline$<0.065$ & 0.16 & 53.00 & $<0.065$ & $<1$ & $<0.065$ & $<0.065$ & $<0.065$ & $<0.065$ & $<0.065$ \\
\hline 0.81 & 0.44 & $90 \cdot 40$ & 0.11 & 0.52 & $<0.025$ & 0.04 & 0.03 & 0.03 & 0.04 \\
\hline$<0.12$ & 0.26 & 116.00 & $<0.12$ & $<2$ & 0.15 & $<0.12$ & 0.16 & $<0.12$ & 0.17 \\
\hline 0.09 & 0.59 & 88.60 & 0.13 & $<1$ & $<0.082$ & $<0.082$ & $<0.082$ & $<0.082$ & $<0.082$ \\
\hline $69 \cdot 4$ & 19.0 & 4290.0 & $3 \cdot 2$ & 28.0 & $<0.084$ & 0.3 & $<0.084$ & $2 \cdot 0$ & $1 \cdot 1$ \\
\hline $9 \cdot 1$ & $3 \cdot 3$ & $2210 \cdot 0$ & 0.6 & $21 \cdot 7$ & $<0.471$ & $<0.471$ & $<0.471$ & $<0.471$ & $<0.471$ \\
\hline 1.02 & 1.64 & 471.00 & $<0.484$ & 1.32 & $<0.484$ & 0.51 & $<0.484$ & $<0.484$ & 0.50 \\
\hline n.d. & n.d. & n.d. & n.d. & n.d. & $-2 \cdot 1$ & n.d. & $-2 \cdot 4$ & n.d. & n.d. \\
\hline
\end{tabular}

Ala-Pen, Ala-Penikka; Keski-Pen, Keski-Penikka; Sompuj, Sompujärvi. Opx, orthopyroxenite; OIPx, olivine pyroxenite. GN, gabbronorite; Anorth, anorthosite; Webs, websterite. Major elements determined by ICP-OES, trace elements by ICP-MS, S and C by elemental infrared analysis, Se by TCF-INAA, and PGE by ICP-MS after Ni sulphide fire assay. n.d., not determined. 
Table 4: Sm-Nd isotopic analyses of rocks of the Penikat intrusion

\begin{tabular}{|c|c|c|c|c|c|c|c|c|c|}
\hline $\begin{array}{l}\text { Sample/ } \\
\text { analysis no. }\end{array}$ & Rock type & $\begin{array}{l}\text { Sm } \\
(\mathrm{ppm})\end{array}$ & $\begin{array}{l}\mathrm{Nd} \\
\text { (ppm) }\end{array}$ & $\begin{array}{l} \pm 0.5 \% \\
0.0050\end{array}$ & $\begin{array}{l}{ }^{143} \mathrm{Nd} / \\
{ }^{144} \mathrm{Nd}\end{array}$ & 2SE & $\mathrm{T}(\mathrm{Ma})$ & $\operatorname{eps}(T)$ & $\begin{array}{l}\mathrm{T}_{\mathrm{DM}} \text { (Ma) } \\
\text { DePaolo }\end{array}$ \\
\hline P12 & Bronzitite & 0.38 & 1.74 & 0.0007 & 0.511499 & 0.000020 & 2440 & $-1 \cdot 8$ & 2883 \\
\hline P15 & Gabbronorite & 1.04 & 4.48 & 0.0007 & 0.511584 & 0.000010 & 2440 & $-3 \cdot 1$ & 3082 \\
\hline P23 \#2 & $\begin{array}{l}\text { Peridotite- } \\
\quad \text { pyroxenite (SJ reef) }\end{array}$ & 0.20 & 0.67 & 0.0009 & 0.512402 & 0.000013 & 2440 & 1.0 & \\
\hline P28 & Gabbronorite & 0.96 & 3.99 & 0.0007 & 0.511757 & 0.000010 & 2440 & $-1 \cdot 3$ & 2924 \\
\hline P33 \#2 & Gabbronorite & 0.95 & 3.70 & 0.0008 & 0.511912 & 0.000012 & 2440 & -1.4 & 3017 \\
\hline P37 & Gabbronorite & 1.45 & $6 \cdot 76$ & 0.0006 & 0.511459 & 0.000010 & 2440 & $-2 \cdot 1$ & 2903 \\
\hline P39 & Gabbro & 0.91 & 4.26 & 0.0006 & 0.511438 & 0.000010 & 2440 & -2.4 & 2922 \\
\hline
\end{tabular}

below), the ultramafic rocks contain mostly between 10 and $20 \%$ trapped liquid (Fig. 13d). This suggests that the rocks are meso- and orthocumulates, consistent with the proportion of intercumulus plagioclase in the rocks. Adcumulates, such as those developed in parts of the Lower and Lower Critical Zones of the Bushveld Complex, are not present. For the gabbroic rocks, an estimation of trapped liquid component is not attempted, as many of the rocks probably crystallized from a more evolved liquid and/or reacted with percolating trace element rich melt. However, what can be said is that the Penikat anorthosites tend to have significantly more intercumulus pyroxene than many Bushveld anorthosites, reflected in the fact that none of our anorthosite samples, nor those of Halkoaho et al. (1989b), contain less than about $2 \% \mathrm{MgO}$ and $>25 \% \mathrm{Al}_{2} \mathrm{O}_{3}$, whereas in the Bushveld Upper Critical Zone anorthosite adcumulates with $<1-2 \% \mathrm{MgO}$ and $>25 \% \mathrm{Al}_{2} \mathrm{O}_{3}$ are common (Maier \& Eales, 1997).

Most samples from across the Penikat intrusion have fractionated primitive mantle normalized incompatible element patterns that show strong negative $\mathrm{Nb}-\mathrm{Ta}, \mathrm{P}$, and $\mathrm{Ti}$ anomalies (Fig. 14). One of the samples from MCU I is relatively depleted in most trace elements, but shows a positive $\mathrm{Nb}-\mathrm{Ta}$ anomaly. Two samples (one each from MCU II and IV) are relatively unfractionated. Several samples from MCU III and the SJ Reef lack negative $\mathrm{Nb}-\mathrm{Ta}$ and $\mathrm{Ti}$ anomalies, and several mineralized SJ reef samples (unlike most samples from the other reefs) are characterized by distinct positive $\mathrm{Zr}-\mathrm{Hf}$ anomalies. However, these samples tend to be relatively altered and thus it is possible that some of the patterns reflect selective element mobility.

The compositional variation with height through the intrusion is summarized in Fig. 15. Elevated MgO contents are characteristic of the pyroxene- and olivine rich rocks, but concentrations above $30 \mathrm{wt} \% \mathrm{MgO}$ are confined to MCU II and MCU III and the base of MCU IV. The basal portions of all MCUs are relatively enriched in $\mathrm{Cr}$, resulting from the presence of chromite disseminations, layers or stringers. The remainder of MCU I-III is somewhat less $\mathrm{Cr}$ enriched, but still contains $>1000$ ppm Cr. MCU IV is different; its base is characterized by chromite enrichment located within a relatively thin, highly altered pyroxenite that in most cases also hosts the bulk of the PGE enrichment. However, this is overlain by ultramafic and mafic rocks that contain $<400$ ppm $\mathrm{Cr}$, reflected by strong $\mathrm{Cr}$ depletion in augite ( $<0.2$ wt \% $\mathrm{Cr}_{2} \mathrm{O}_{3}$ at an Mg\# of 0.75-0.8; Halkoaho, 1993; Alapieti \& Halkoaho, 1995). There is a marked compositional reversal towards less evolved compositions at the base of MCU V, particularly in terms of the Cr content of the whole-rocks and augite. The modified differentiation index (Fig. 4) also shows a distinct reversal at this stratigraphic level. The mafic rocks of MCU IV and $\mathrm{V}$ are characterized by subdued fractionation, analogous to that seen in the Main Zone of the Bushveld Complex and the mafic zone of the Great Dyke (Wilson \& Chaumba, 1997; Maier et al., 2013).

Regarding the immobile incompatible trace elements, the analysed profile shows slightly elevated $\mathrm{Zr}$, Th and $\mathrm{P}$ contents in the basal samples, followed by relatively low contents throughout MCU II and III, a slight increase through MCU IV, a strong peak in some PV reef samples and then mostly relatively high values in MCU V. The SJ reef is not enriched in incompatible elements relative to its footwall and hanging-wall (Fig. 16), but isolated zircon grains, up to $0.5 \mathrm{~mm}$ in width, have been described by Halkoaho et al. (1990a) in sample Si/Ki-153/98.75.

Ratios of incompatible elements may also serve as an indicator of differentiation. $\mathrm{Ce} / \mathrm{Sm}$ shows little systematic variation through the intrusion, plotting in the range of the putative SHMB and tholeiitic parent magmas (Guo \& Maier, 2013). However, there is a marked change at the base of $\mathrm{MCU} \mathrm{V}$, where $\mathrm{Ce} / \mathrm{Sm}$ increases from $\sim 8$ to 11 . Values of $\varepsilon N d$ are mostly around -2 , in the range of Finnish $2.45 \mathrm{Ga}$ layered intrusions and SHMB dykes (Hanski et al., 2001; Hanski, 2012). The analysed SJ reef sample forms an exception in having a higher $\varepsilon N d$ value $(+1)$ typical of Finnish $2.45 \mathrm{Ga}$ tholeiitic dykes (Vuollo, 1994; Vuollo \& Huhma, 2005). However, this sample has very low REE contents and it is possible that the $\mathrm{Sm} / \mathrm{Nd}$ ratio is not primary.

\section{Variations in ore elements}

The Penikat intrusion contains at least six intervals of significant PGE enrichment (Fig. 15b), mostly associated with compositional discontinuities in the igneous stratigraphy, analogous to PGE reefs in many other PGE-mineralized layered intrusions. The SJ and AP reefs occur in rocks of distinctly more evolved 


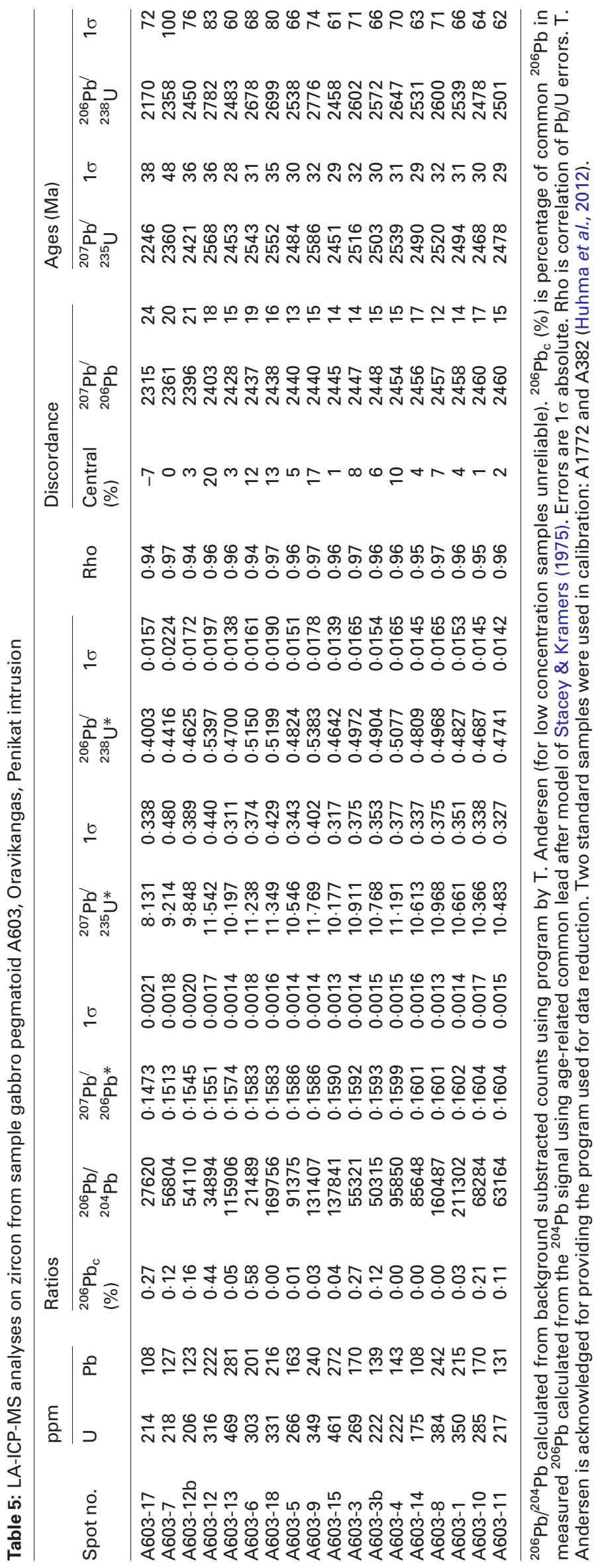




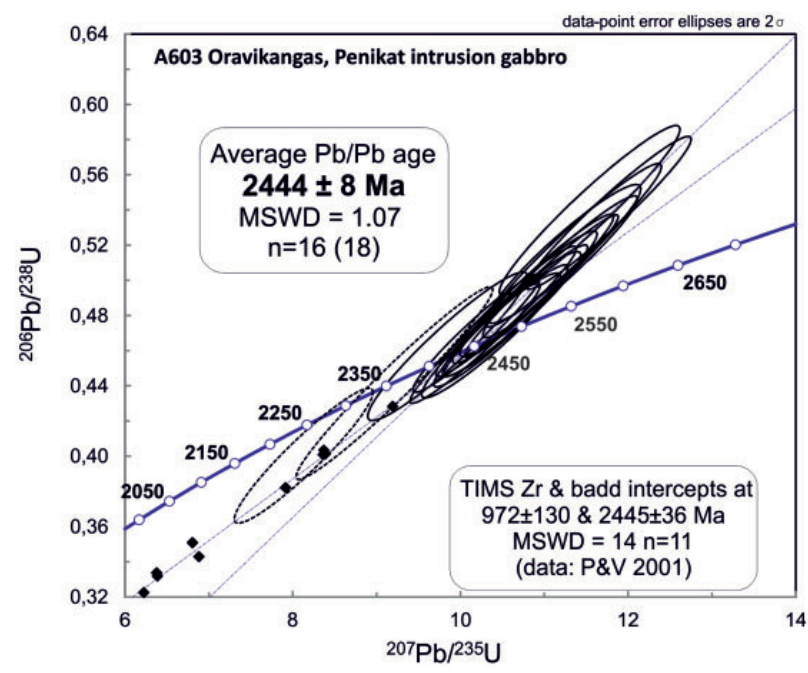

Fig. 12. Concordia diagram showing zircon $\mathrm{U}-\mathrm{Pb}$ isotope data for gabbro pegmatoid sample A603-Oravikangas from the Penikat intrusion, determined using LA-ICP-MS on zircon. Black diamonds indicate TIMS analyses after Perttunen \& Vaasjoki (2001) (P\&V 2001). The LA-ICP-MS error ellipses are at $2 \sigma$. composition than their footwall, as discussed in more detail below. In contrast, the PV reef is more 'primitive' than its footwall, as reflected by higher whole-rock $\mathrm{Cr} / \mathrm{V}$, as well as the Mg\# of whole-rocks and augite.

The intrusion displays a general trend of progressive PGE fractionation with height, expressed by increasing $(\mathrm{Pt}+\mathrm{Pd}) /(\mathrm{IPGE}+\mathrm{Rh})$, albeit with several reversals. The lowest values occur in MCU I and at the base of MCU II, III, and IV. Notably, the bulk of the intrusion has higher $\mathrm{Cu} /(\mathrm{Pt}+\mathrm{Pd}$ ) than the primitive mantle (i.e. it is $\mathrm{PGE}$ depleted). Fertile rocks [i.e. those with $\mathrm{Cu}$ / $(\mathrm{Pt}+\mathrm{Pd})<3000]$ mainly occur at the ultramafic base of MCU II, III and IV and in some gabbroic-anorthositic rocks of MCU IV (e.g. in and around the AP and PV reefs). This is in marked contrast to the Bushveld Complex, where the bulk of the Lower Zone and Critical Zone have $\mathrm{Cu} /(\mathrm{Pt}+\mathrm{Pd})$ ratios below primitive mantle levels (Maier et al., 2013). Cu/Zr ratios are mostly between three and 100 (not shown), significantly higher than in Finnish SHMB and tholeiites (Guo \& Maier, 2013). S/Se ratios are broadly around the mantle value
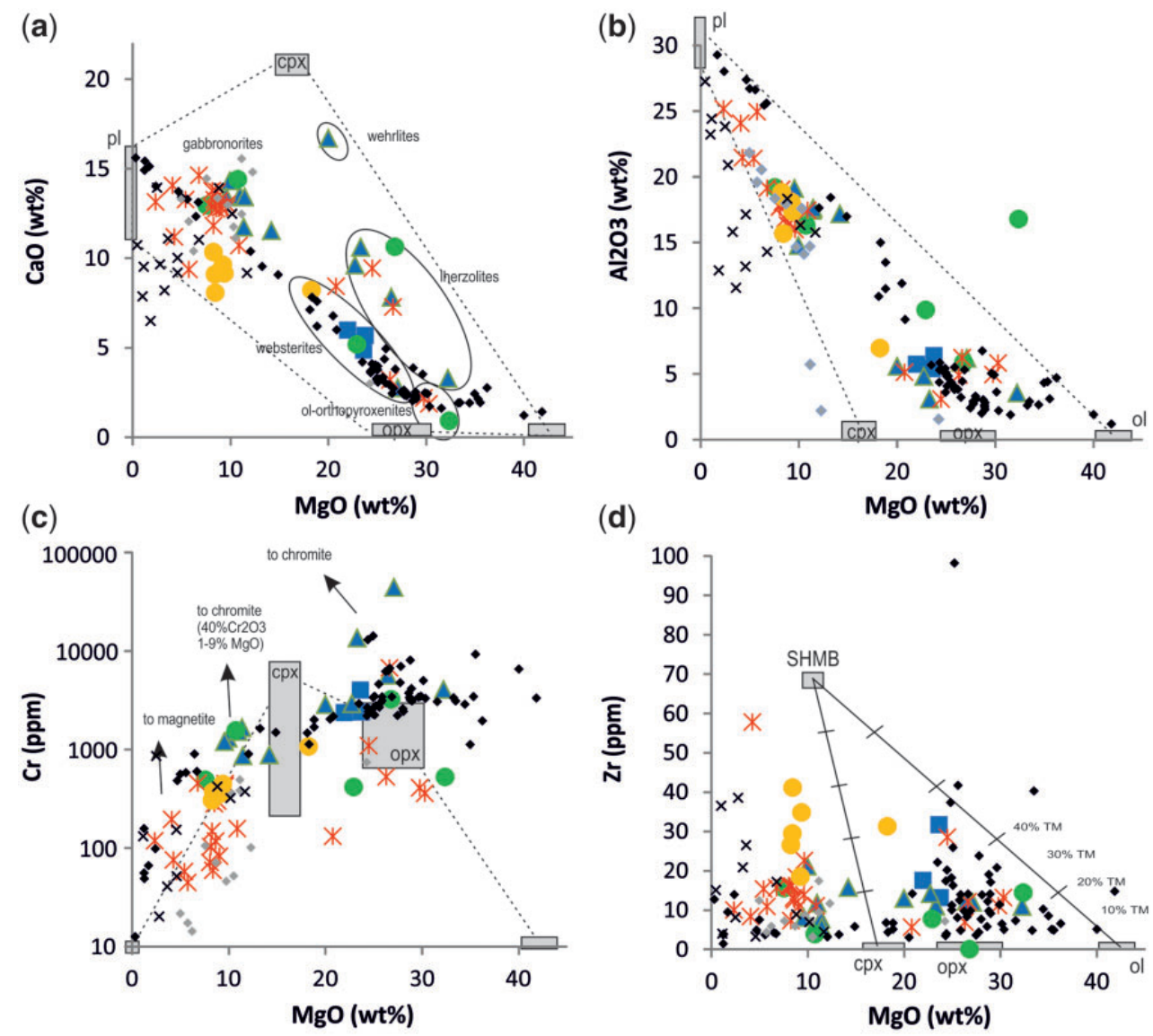

\begin{tabular}{|c|c|c|}
\hline Penikat & & Bushveld \\
\hline MCU I & MCU III MCU V & $\times$ UZ $\bullet \mathrm{LZ}$ and CZ \\
\hline$\triangle \mathrm{MCU}$ II & * MCU IV & $\bullet \mathrm{MZ}$ \\
\hline
\end{tabular}

Fig. 13. Binary variation diagrams of major, minor and trace elements plotted vs $\mathrm{MgO}$. (a) $\mathrm{CaO}$ vs $\mathrm{MgO}$. (b) $\mathrm{Al}_{2} \mathrm{O}_{3}$ vs $\mathrm{MgO}$. It should be noted that samples define two distinct fields, one being ultramafic and the other mafic. Intermediate samples are absent. (c) $\mathrm{Cr}$ vs $\mathrm{MgO}$. (d) Zr vs MgO. Many of the ultramafic samples contain in excess of $10 \%$ trapped liquid. 

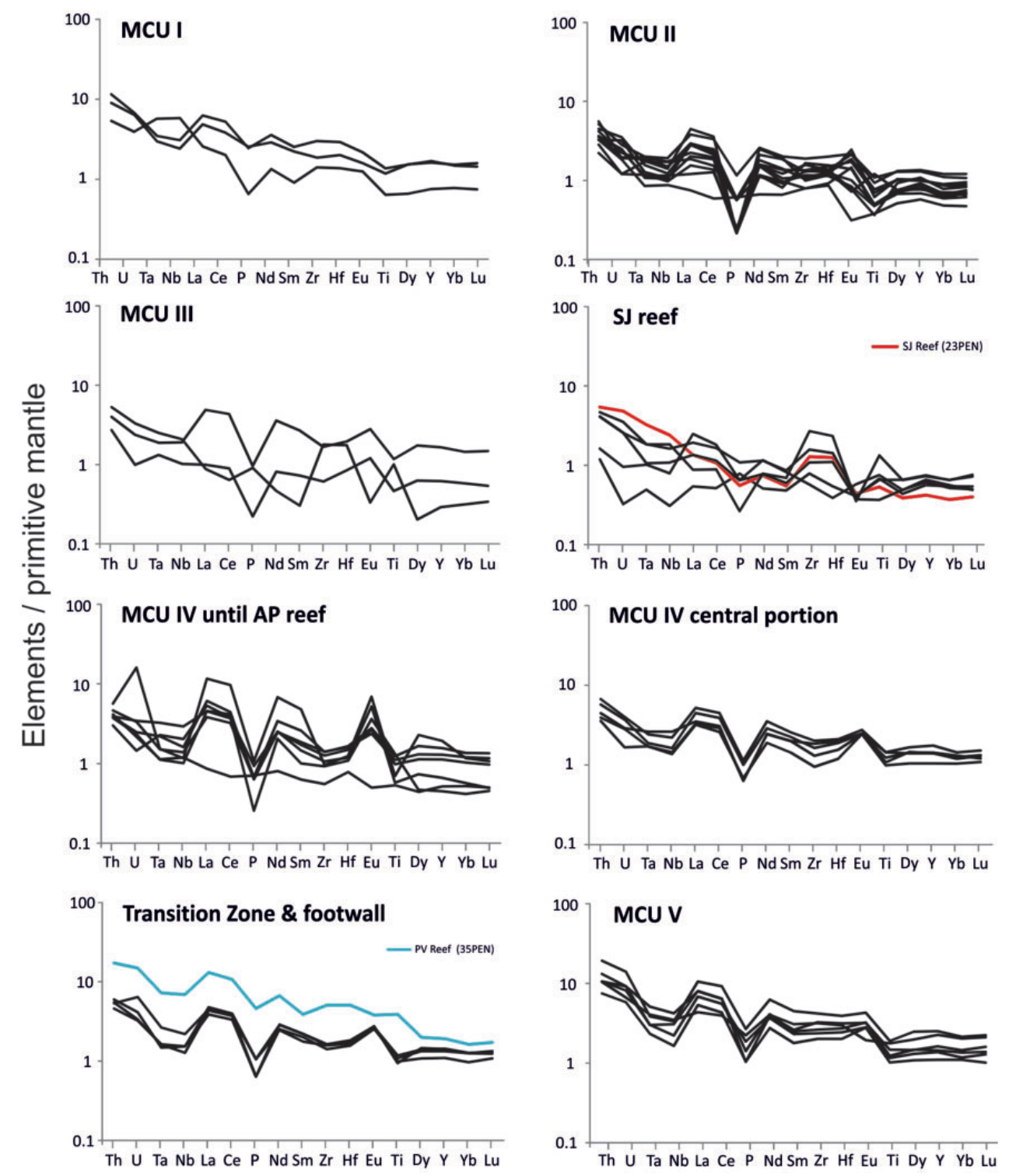

Fig. 14. Primitive mantle normalized incompatible element variation diagrams. Normalisation factors are from Sun and McDonough (1989).

throughout most of the intrusion. However, no samples from the relatively S-poor SJ reef were analysed.

There is generally a good correlation between PPGE and IPGE contents in the intrusion as a whole and in the PGE reefs in particular (Fig. 17), but relatively large scatter in the binary $\mathrm{Cu}$ vs Pd plot (Fig. 17d). Figure 18 also illustrates that the AP reefs have a markedly higher $\mathrm{Pd} / \mathrm{Pt}$ than the SJ and PV reefs, and higher $\mathrm{Pd} / \mathrm{lr}$ (Halkoaho et al., 1989a, 1989b, 1994; Huhtelin et al., 1989a, 1990; Halkoaho, 1993).

Primitive mantle normalized chalcophile element patterns are shown in Fig. 18. In MCU I, the patterns are relatively unfractionated, resembling those of Finnish SHMB dykes (Guo \& Maier, 2013) and the Loljunmaa dyke, previously suggested to represent a potential parent magma to the Penikat intrusion (Alapieti \& Lahtinen, 1989; Halkoaho, 1993). In MCU II and III, as well as the chromitite layers and the SJ reef, the patterns are bell-shaped, reflecting the PGE enrichment of many samples. Many of the rocks in MCU II-IV have pronounced negative $\mathrm{Ru}$ anomalies, as previously noted by Halkoaho et al. (1989a, 1989b, 1990a, 1990b). In MCU IV and V, the chalcophile element patterns are trough shaped. The SJ and, in particular, the AP reefs have strong positive $\mathrm{Pd}$ anomalies, whereas in many samples from MCU I-III (including the chromitites) this is much less marked, with some samples having higher normalized Pt than Pd values. The PV reef shows positive Pt anomalies.

\section{DISCUSSION}

\section{Composition of Penikat parental magma}

Knowledge of the composition of the parent magmas to layered intrusions is of key importance in constraining the prospectivity of the intrusions for magmatic ore 
(a)

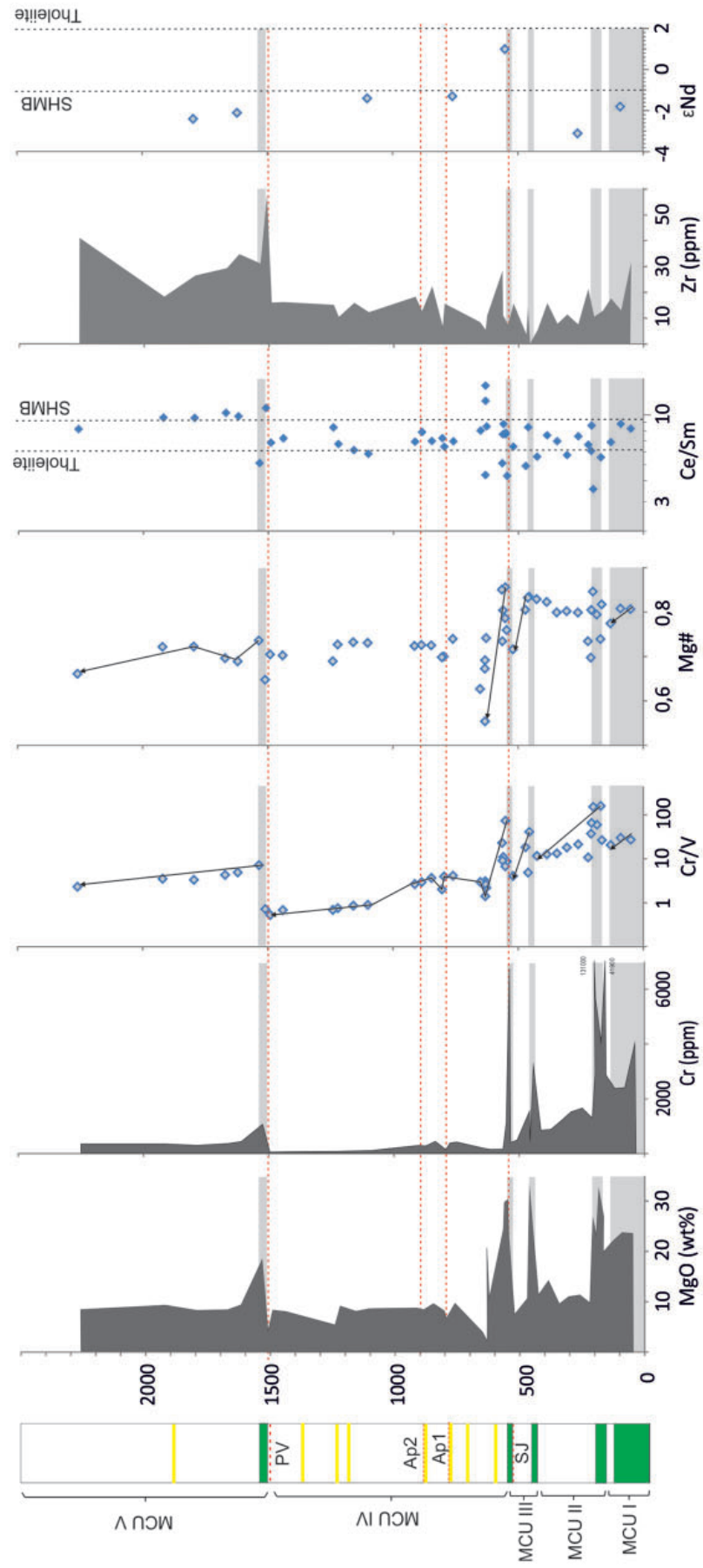

(b)

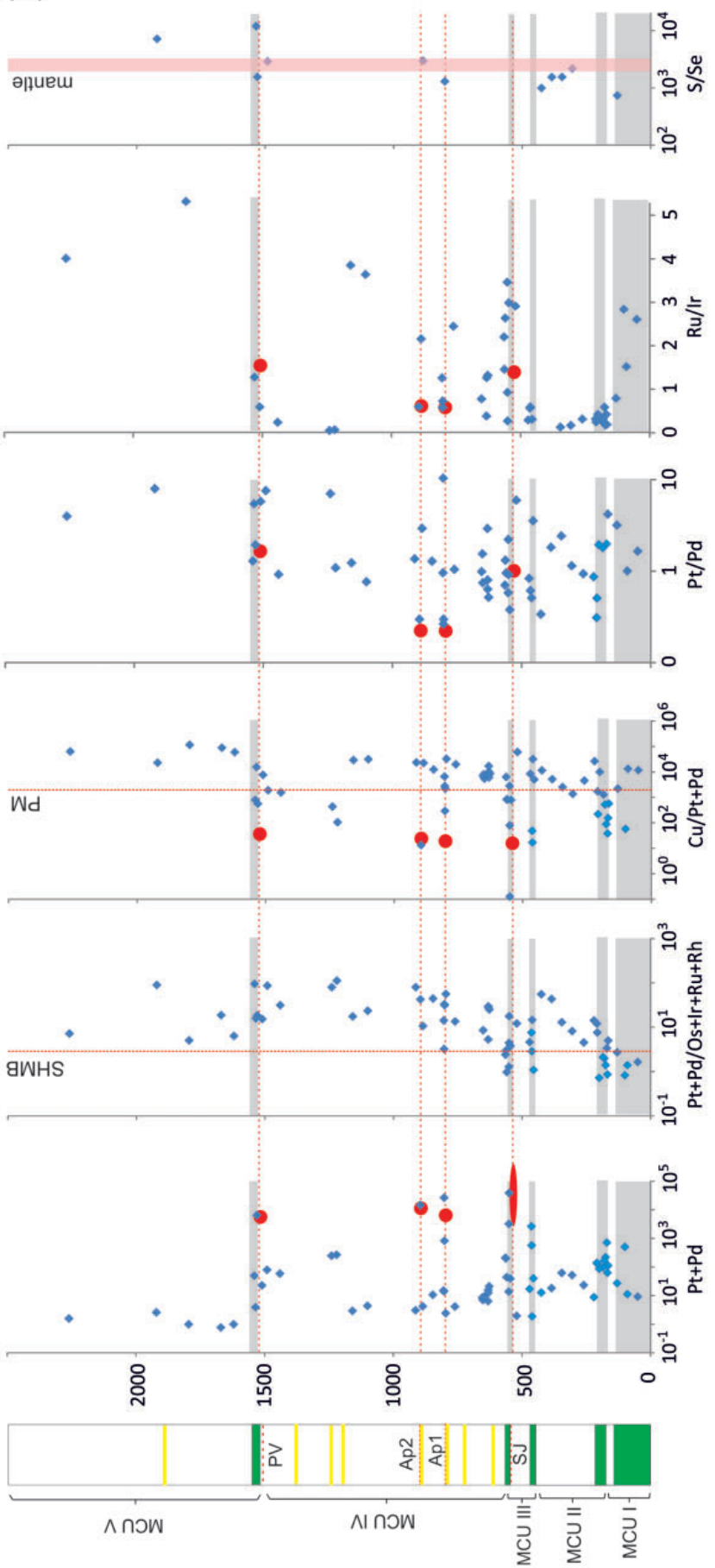

Fig. 15. (a) Compositional variation of lithophile elements with stratigraphic height (in m). (b) Variation in chalcophile elements with height $(\mathrm{m})$. Red circles and ellipsoids represent compositional variation in main reefs. Green, ultramafic rocks; white, gabbroic and noritic rocks; yellow, anorthosite.

deposits. However, for most intrusions, the parental magma composition remains poorly known, with the notable exception of the Bushveld Complex (Sharpe, 1981; Barnes et al., 2010). In the case of the Finnish layered intrusions, including Penikat, a suite of c. $2.45 \mathrm{Ga}$ mafic dykes emplaced in the Archaean basement rocks is generally considered to represent the best candidate for the parent magmas (Alapieti et al., 1990; Halkoaho, 1993; Saini-Eidukat et al., 1997; Alapieti \& Lahtinen, 2002). The dykes are grouped into two main populations, SHMB and tholeiites (Vuollo \& Huhma, 2005). The SHMB dykes contain, on average, 11.3 wt \% MgO, 960 ppm Cr, and 310 ppm Ni (Table 1). The average initial $\varepsilon N d$ value is around -2 , and the incompatible 

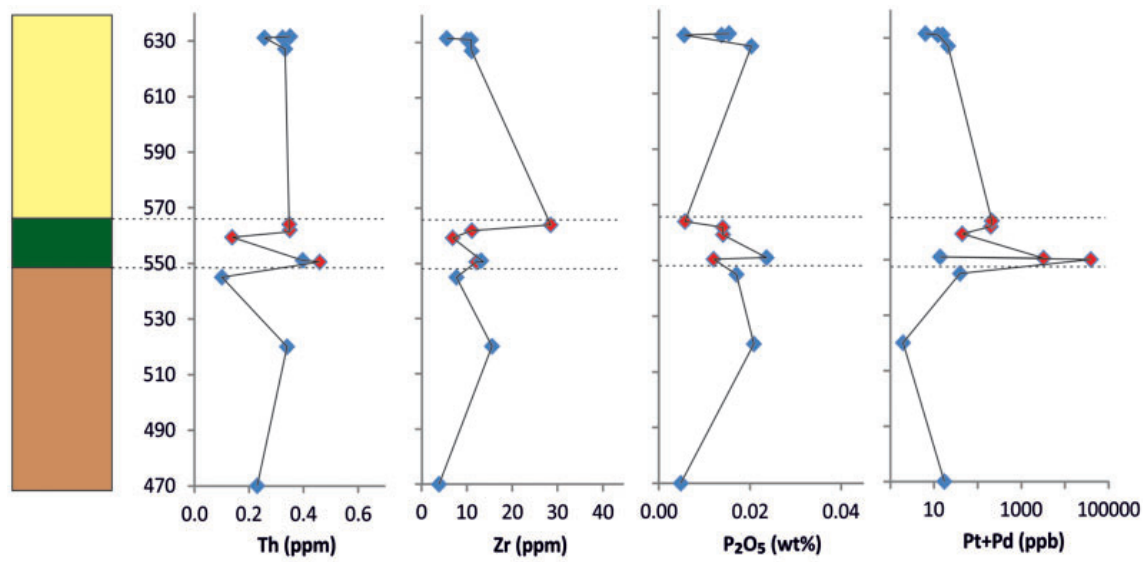

Ol-pyroxenite $\square$ Norite $\square$ Gabbronorite

Fig. 16. Compositional profile across the SJ reef, based on outcrop samples. The lack of enrichment in incompatible elements in the reef should be noted.

(a)

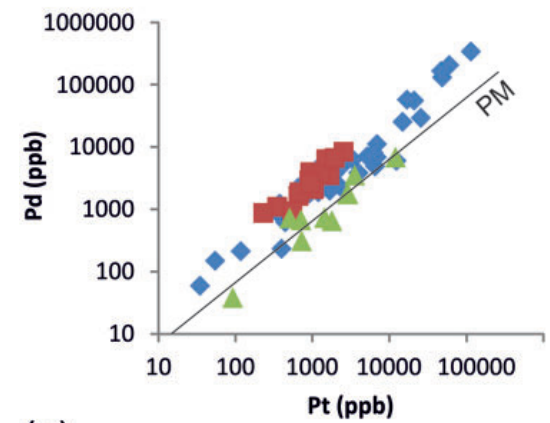

(c)

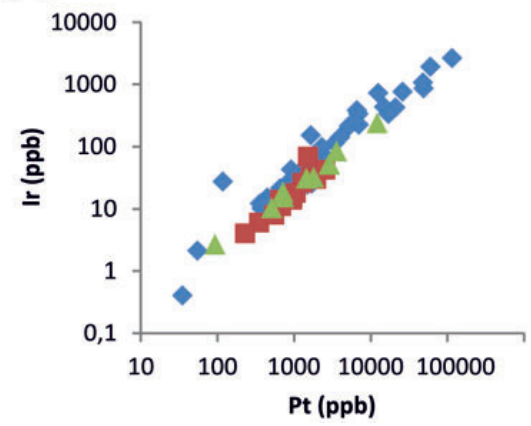

(b)

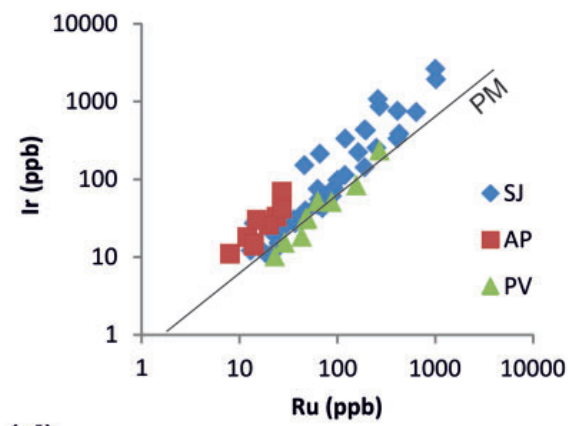

(d)

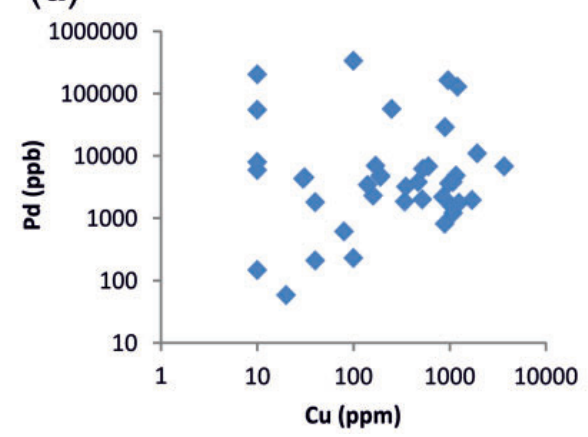

Fig. 17. Binary variation diagrams of PGE. (a) Pd vs Pt. It should be noted that the different reefs have systematically distinct Pt/Pd, with PV higher than SJ and AP. (b) Ru vs Ir. It should be noted that AP has Ru/lr below that of primitive mantle, whereas PV has Ru/ Ir approximately at the level of PM. SJ reef samples form two groups, one with AP-like Ru/lr and the other with PV-like Ru/lr. (c) Pt vs Ir. The good correlation between Pt and Ir, suggesting that PGE are concentrated by a magmatic process, should be noted. (d) $\mathrm{Cu}$ vs $\mathrm{Pd}$ (SJ reef data only). Scatter suggests that Cu was mobile after solidification.

elements are strongly fractionated, with pronounced negative $\mathrm{Nb}-\mathrm{Ta}$ and $\mathrm{Ti}$ anomalies (Fig. 19). In the vicinity of the Penikat intrusion, the SHMB group is represented by the Loljunmaa dyke, located immediately to the east of the intrusion (Fig. 2; Alapieti \& Lahtinen, 1989; Alapieti et al., 1990). The dyke has $11.2 \mathrm{wt} \% \mathrm{MgO}$, 0.86 wt $\% \mathrm{TiO}_{2}, 990$ ppm Cr, 350 ppm Ni, and 420 ppm S. $\varepsilon \mathrm{Nd}$ is -1.2 (Yang et al., 2016). The Finnish SHMB dykes have a composition that resembles the Bushveld B1 magma in terms of major and compatible trace element contents (Table 1), and the shape of incompatible trace element patterns (Fig. 19). However, the former are somewhat less enriched in REE (e.g. 10 vs 18 ppm La) and have less than half the average PGE contents of Bushveld B1 (7 ppb Pt and 6 ppb Pd vs $19 \mathrm{ppb} \mathrm{Pt}$ and 13 ppb Pd; Barnes et al., 2010; Guo \& Maier, 2013). The Finnish tholeiite dykes have, on average, $6 \mathrm{wt} \% \mathrm{MgO}$, $120 \mathrm{ppm} \mathrm{Cr}$, $70 \mathrm{ppm} \mathrm{Ni}$, and $\varepsilon \mathrm{Nd} \mathrm{+1}$, with less 

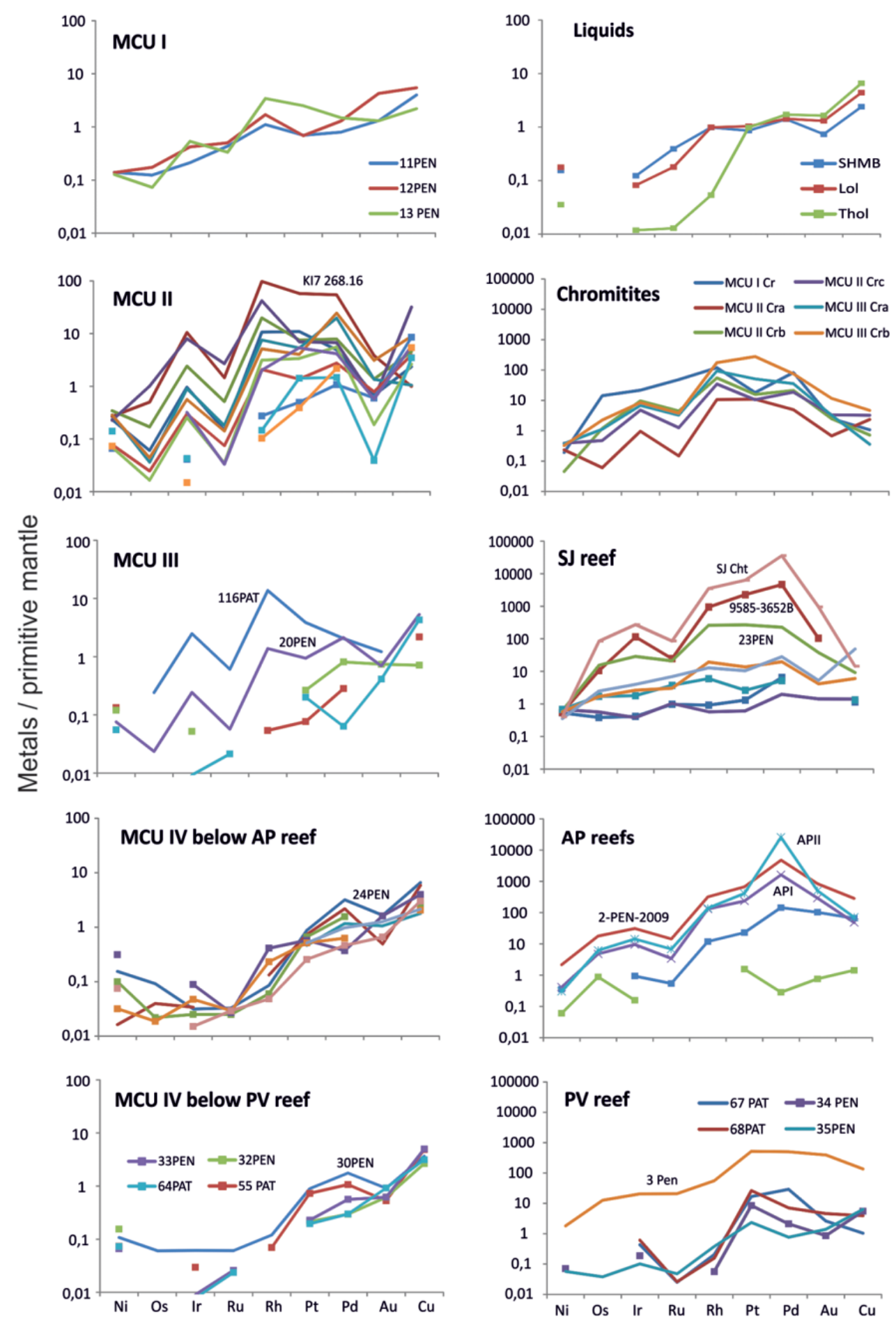

Fig. 18. Primitive mantle normalized multi-element variation diagrams for PGE. Normalization factors are from Barnes \& Maier (1999).

fractionated trace element patterns and less prominent negative $\mathrm{Nb}-\mathrm{Ta}$ and $\mathrm{Ti}$ anomalies (Guo \& Maier, 2013). They do not show strong compositional overlap with most of the Penikat cumulates.

In addition to the dykes, we could also consider the chilled margins of the Penikat intrusion as representing parental liquids. On average, the chilled margins contain $7.2 \mathrm{wt} \% \mathrm{MgO}$ and are relatively rich in $\mathrm{Cr}$ (around
$450 \mathrm{ppm})$, consistent with an SHMB lineage. However, the rocks have relatively high $\mathrm{K}_{2} \mathrm{O}$ contents (4.5-5.7 wt $\%$ ) suggesting that they are contaminated (Halkoaho, 1993). Notably, they have slightly higher Pd contents (average of $13 \mathrm{ppb} \mathrm{Pd}$ ) than the average Finnish SHMB, possibly owing to their more evolved nature. Sulphide contents are very low (180-270 ppm S), ruling out the possibility that the relatively high PGE contents are due 

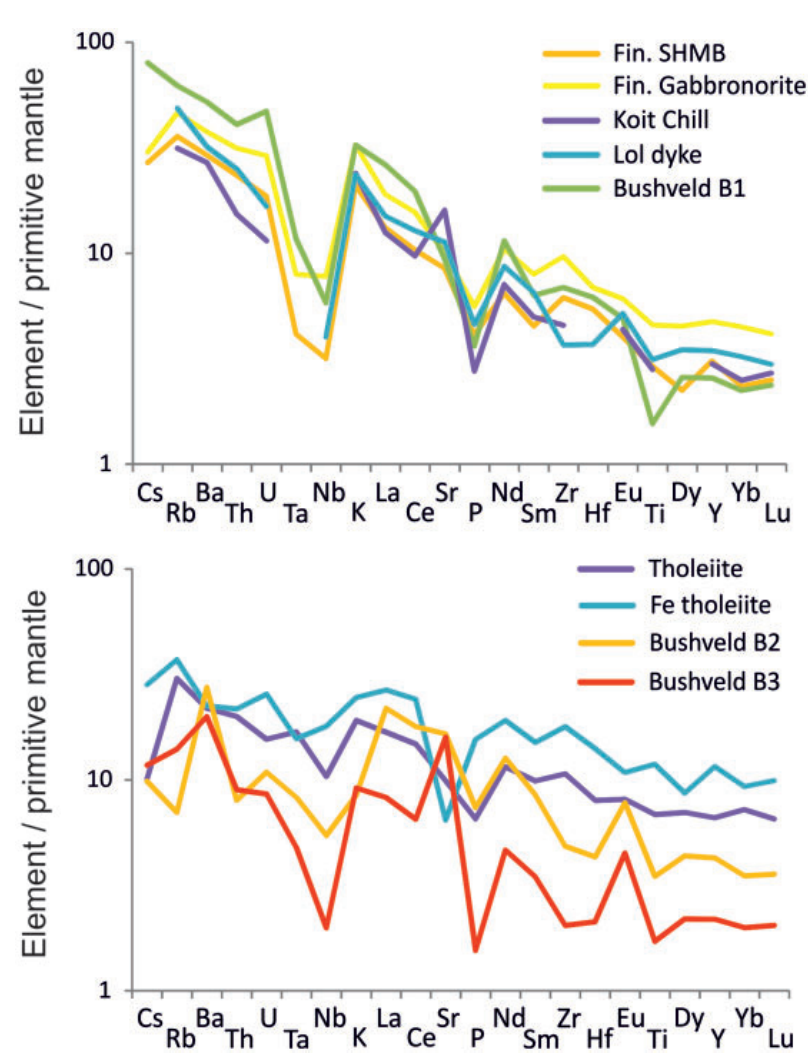

Fig. 19. Multi-element variation diagrams for lithophile elements for Finnish $2.45 \mathrm{Ga}$ dykes (Guo \& Maier, 2013) as well as aphanitic marginal rocks of the Bushveld Complex (Bushveld data from Barnes et al., 2010; Koitelainen data from Hanski et al., 2001). The similarities between Finnish SHMB and Bushveld B1 magmas should be noted. Normalization factors from Sun \& McDonough (1989).

to the presence of small amounts of sulphide, unless metamorphism has removed some $\mathrm{S}$.

To further constrain whether any of the above magmas may have been parental to the Penikat intrusion, it is first necessary to examine whether the magmas and the cumulates share a similar crystallization sequence. To this effect, we have modelled the crystallization sequence of the dykes using PELE (Boudreau, 1999). At low to intermediate pressure, $\mathrm{fO}_{2}$ at the quartz-fayalitemagnetite (QFM) buffer, and $0.1 \mathrm{wt} \% \mathrm{H}_{2} \mathrm{O}$, Finnish SHMB and the Loljunmaa dyke have a crystallization order of sp-ol-pl-cpx (1 kbar) or sp-ol-opx-pl-cpx (3 kbar), with starting mineral compositions of Fo87 and An 67-69. The crystallization order is broadly similar to that observed in many of the Penikat MCUs (notably II, III and IV) suggesting that the intrusion was emplaced at a moderate depth of $<5 \mathrm{~km}$. However, the observed olivine and pyroxene compositions in the least evolved Penikat rocks are less magnesian than the model compositions, and plagioclase has higher An. The low An contents of plagioclase in the crystallization model reflect the relatively high $\mathrm{Na}$ contents of the SHMB dykes, possibly resulting from metasomatism during Svecofennian $(c .1 .9 \mathrm{Ga}$ ) metamorphism. The relatively low $\mathrm{Mg} \#$ of the Penikat cumulates may reflect $10-15 \%$ fractionation of the SHMB prior to final emplacement.
In view of the significant contamination of the Penikat magmas discussed below, it seems plausible to argue that the SHMB must have contained significant water. However, adding $1 \mathrm{wt} \% \mathrm{H}_{2} \mathrm{O}$ to the magma results in a modelled crystallization order of olivine, followed by the appearance of clinopyroxene ( $\mathrm{Mg \#} \mathrm{84)} \mathrm{be-}$ fore orthopyroxene and plagioclase, inconsistent with the observed crystallization order. The composition of the main cumulus phases is little affected by adding $1 \%$ $\mathrm{H}_{2} \mathrm{O}$.

MCU IV has significantly lower Mg\# and Cr contents in clinopyroxene and whole-rocks than MCU III (Alapieti et al., 1990). Alapieti et al. proposed that MCU IV (and V) crystallized from Cr-poor tholeiitic magma as, for example, represented by the chilled margin of the Koillismaa intrusion. However, based on PELE modelling, the Finnish tholeiitic dykes have a crystallization order of pl-cpx-opx and thus seem inappropriate parental magmas for the cyclic units of the Penikat intrusion. The low $\mathrm{Cr}$ contents $(<400 \mathrm{ppm}$ in the rocks, $<0.2$ wt $\% \mathrm{Cr}_{2} \mathrm{O}_{3}$ in augite) and $\mathrm{Mg \#}$ of augite $(<80)$ of MCU IV can instead be explained by crystallization from a more fractionated SHMB magma. For example, after $40 \%$ crystallization, the SHMB has $3.8 \mathrm{wt} \% \mathrm{MgO}$, 276 ppm Cr, Di 78, En 77 and An 60. This model is more consistent with the relative homogeneity in isotope and trace element signature across the intrusion than a model invoking the presence of several magmas of contrasting lineage. The sharp compositional break between MCU III and IV could reflect emplacement of MCU IV magma from a staging chamber, whereas the reversal at the base of $M C U \mathrm{~V}$ could reflect replenishment with relatively un-evolved magma, or MCU V could be the residual magma of MCU III, displaced by the voluminous MCU IV influx.

The negative Ru anomalies found in MCU II and III as well as in the SJ, AP and PV reefs are not matched in the potential parent liquids to the intrusion (Fig. 18) and thus appear to have formed within the Penikat magma chamber, or a staging chamber. One possibility is that $\mathrm{Ru}$ was removed by fractionating chromite (Arguin et al., 2016); for example, in chromite slurries sliding towards the subsiding centre of the lopolith.

\section{Mantle source to parental magmas and importance of crustal contamination}

As has been pointed out by numerous previous researchers, the enriched chemical signature of SHMB (high $\mathrm{Ce} / \mathrm{Sm}$, negative $\varepsilon \mathrm{Nd}$, negative $\mathrm{Ti}$ anomalies, high Si content expressed by appearance of orthopyroxene before clinopyroxene on the liquidus) is consistent with magma derivation either from subcontinental lithospheric mantle (SCLM), or by melting of asthenospheric mantle followed by crustal contamination during magma ascent (Barnes, 1989, Amelin et al., 1995; Amelin \& Semenov, 1996; Hanski et al., 2001; Barnes et al., 2010; Yang et al., 2016). For Penikat, the weight of the available evidence is in favour of the latter model, 
for the following reasons. (1) The SCLM generally lacks negative $\mathrm{Nb}$ and $\mathrm{Ta}$ anomalies that are characteristic of the Penikat rocks and the SHMB dykes (Gregoire et al., 2002; Simon et al., 2007; lonov, 2010; Maier et al., 2012; Arndt, 2013). (2) Coeval basaltic to komatiitic rocks with enriched and broadly similar isotopic and trace element signatures to the Finnish SHMB dykes are exposed in the Vetreny Belt, Russian Karelia. Their compositional variation has been interpreted to result from assimilation of variable amounts of continental crust (Puchtel et al., 1997). (3) The Kemi intrusion has positive initial $\gamma$ Os that can best be modelled by contamination of asthenospheric magma during ascent through the crust, whereas SCLM derivation is inconsistent with the Os isotope data (Yang et al., 2016).

We have used $\mathrm{Nd}$ isotope and trace element data to further constrain the nature of potential crustal contaminants. Figure 20 shows bulk-mixing lines between a komatiitic parental magma and five examples of Finnish granitoids with different isotopic compositions and ages. In reality, contamination probably involved combined assimilation and fractional crystallization (AFC) instead of bulk mixing between magma and crust. Nevertheless, when the crystallized minerals do not significantly change the $\mathrm{Sm} / \mathrm{Nd}$ ratio of the melt, as can be assumed to be the case in a high-MgO basaltic to komatiitic system crystallizing olivine and clinopyroxene,

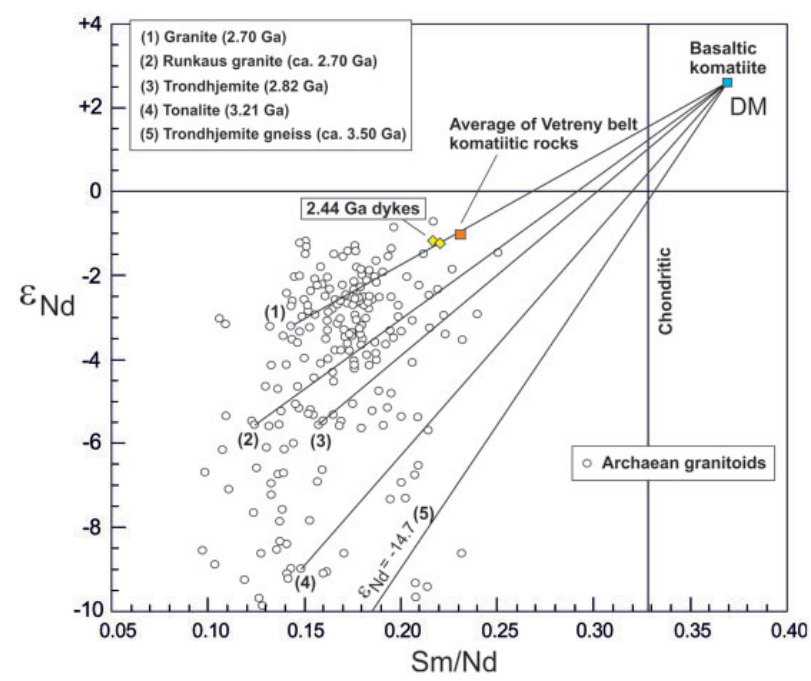

Fig. 20. $\mathrm{Sm} / \mathrm{Nd}$ vs $\varepsilon \mathrm{Nd}$ for Archaean granitoids from the Karelian craton (literature data) and the $2.44 \mathrm{Ga}$ Loljunmaa and Viianki dykes (Yang et al., 2016). Also shown are mixing lines of basaltic komatiite generated from depleted mantle and five selected examples of different granitoids: (1) $2.70 \mathrm{Ga}$ Surmansuo porphyritic granite (Mikkola et al., 2014); (2) $\sim 2.70 \mathrm{Ga}$ Runkaus K-rich granite, south of the Penikat intrusion, Pudasjärvi block (Huhma et al., 2012); (3) $2.82 \mathrm{Ga}$ Takaaho trondhjemite from Suomussalmi (Mikkola et al., 2011); (4) $3.21 \mathrm{Ga}$ tonalite from the Vodla block, Russian Karelia (Puchtel et al., 2016); (5) $\sim 3.50 \mathrm{Ga}$ granitic leucosome from the Siurua tonalitic gneiss, Pudasjärvi block (Huhma et al., 2012). Isotopic data for the dykes taken from Yang et al. (2016). For comparison, the average $\mathrm{Nd}$ isotope composition of Vetreny Belt komatiites from Puchtel et al. $(1997,2016)$ is also plotted. All $\varepsilon \mathrm{Nd}$ values are calculated at $2 \cdot 44 \mathrm{Ga}$. only very slight deviation from the linear trend occurs during AFC.

There are several Neoarchaean granitoids that can be modelled to produce the isotopic composition of the dykes through AFC, including that of the $2.70 \mathrm{Ga}$ Surmansuo porphyritic granite [(1) in Fig. 20]. It should be noted that the Runkaus granite [(2) in Fig. 20], which forms the footwall to the Penikat intrusion and is cut by the Loljunmaa dyke that may represent a feeder to the intrusion, seems to be an inappropriate contaminant. This is consistent with the trace element and isotope signature of the cumulates that were interpreted largely to reflect contamination in a staging chamber, as discussed above. Mesoarchaean or Palaeoarchaean granitoids with ages of $>3.0 \mathrm{Ga}$ have far too low $\varepsilon \mathrm{Nd}$ $(2440 \mathrm{Ma})$ to have played any role in magma-crust interaction. Assuming a depleted mantle source for the primitive magma, the amount of assimilation required to develop a negative $\varepsilon N d$ value of -1.2 for the dyke magma is dependent on the Nd concentration of the komatiitic magma; that is, the degree of fractionation after its generation, and the $\mathrm{Nd}$ concentration and isotope composition of the contaminant. In the case of the Surmansuo granite, simple mixing with a basaltic komatiite (MgO $17 \mathrm{wt} \%$ ) with 2.14 ppm Nd (see Puchtel et al., 1997) simulates the observed isotope composition of the dyke after $12 \%$ assimilation, and slightly less contamination if an AFC process is assumed.

\section{Origin of the Penikat PGE reefs \\ General}

The origin of PGE reefs in layered intrusions remains controversial despite nearly 100 years of debate (e.g. Wagner, 1929). The main models generally considered are the following.

Model 1. The reefs formed through mixing of compositionally contrasting resident and replenishing magma triggering sulphide liquid immiscibility in the hybrid magma, followed by segregation of the sulphide melt from, and equilibration with, a large body of hybrid magma to achieve high metal tenors (Irvine, 1975; Campbell et al., 1983; Naldrett \& von Gruenewaldt, 1989).

Model 2. The magma from which the PGE reefs crystallized was unusually PGE rich, through assimilation or entrainment of PGE-rich sulphides in a staging chamber (Naldrett et al., 2009; Holwell et al., 2010).

Model 3. The magma in the magma chamber became temporarily supersaturated in sulphide through a sudden increase in pressure; for example, in response to magma replenishment (Cawthorn, 2005). As in model 1 , this was followed by segregation of sulphides through a large magma body, to achieve high $R$ factors.

Model 4. The magma reached sulphide melt saturation through contamination within the chamber; for example, with the roof-rocks. As in models 1 and 2, this was followed by segregation of the sulphide melt through, and collection of metals from, the magma body (Kinnaird et al., 2002). 
Model 5. The formation of the reefs involved late magmatic fluids ascending through the cooling crystal pile, either introducing PGE from the footwall rocks, or concentrating PGE through recrystallization of rocks containing high $R$-factor magmatic PGE (Nicholson \& Mathez, 1991; Boudreau \& McCallum, 1992).

Model 6. The PGE in the reefs precipitated from magma that intruded the cumulate sequence as sills (Mitchell \& Scoon, 2007; Latypov et al., 2015; Mungall et al., 2016).

Model 7. PGE-rich sulphides were concentrated during hydrodynamic sorting of sulphide-bearing cumulate slurries slumping towards the centre of magma chambers that subsided in response to crustal loading (Maier et al., 2013).

Model 8. Sulphide-bearing magma was mobilized from within the cumulate pile; for example, through tectonic readjustment of the chamber (this study).

In the following, we consider in more detail which of these models is most appropriate to explain the formation of the Penikat PGE reefs. It should be borne in mind that most previous studies of PGE reefs in layered intrusions focused on relatively well-exposed and unaltered or weakly altered intrusions, namely Bushveld, Great Dyke, Skaergaard, Rum and Stillwater. Unravelling the petrogenesis of the Penikat reefs is more challenging, owing to pervasive greenschist to amphibolite metamorphism.

\section{Model 1: magma mixing}

This model was originally proposed for the Bushveld and Stillwater intrusions (Irvine, 1975; Campbell et al., 1983; Naldrett \& von Gruenewaldt, 1989) in which numerous compositional reversals have been interpreted as a result of frequent magma replenishment and mixing of magmas with distinct compositional lineages. Campbell et al. (1983) suggested that particularly vigorous magma mixing resulted when plumes of relatively un-evolved replenishing magma intruded into and through relatively dense and evolved resident magma. If both magmas were nearly saturated in sulphide, an immiscible sulphide melt could have formed ( $\mathrm{Li} \&$ Ripley, 2005). Our new geochemical data do not provide clear constraints on the magma mixing model: although the incompatible trace element and $\mathrm{Nd}$ isotope compositions of the Penikat rocks show no evidence for distinct magma lineages, they do not rule out mixing of magmas of similar lineage but different fractionation state. However, a more general criticism of the magma mixing model is that it fails to explain the extremely efficient concentration of sulphide into a narrow layer bounded by rocks that are sulphide- and PGE-poor ( $<40$ ppb PGE/100 ppm S), as observed at Penikat. To attain the observed high metal tenors of the sulphides (hundreds of ppm), it is normally assumed (within the context of the magma mixing model) that the sulphide droplets must have been swirling within, and equilibrated with a large magma body. One would thus expect that the PGE reefs should be much wider and more diffuse than what is observed, particularly as the sulphides in the reefs tend to be much smaller (mostly $=1 \mathrm{~mm}$, based on petrography) than olivine and pyroxene (mostly $>2 \mathrm{~mm}$ ).

\section{Model 2: intrusion of PGE-rich magmas derived from a staging chamber}

Naldrett et al. (2009) argued that concentration of PGE into narrow reefs is not feasible from a basaltic magma with 10-20 ppb PGE, for the reasons outlined above. They thus suggested that the reefs crystallized from unusually PGE-rich magma derived from a staging chamber. Mitchell \& Scoon (2007) had previously argued for reef crystallization from relatively sulphur-rich magmas, and Holwell et al. (2010) found sulphide inclusions within chromite, which they argued indicate entrainment of sulphide from a staging chamber. The main problem with the model is that very few of the dykes or sills that could represent the chilled parent magmas to layered intrusions have been found to be enriched in PGE relative to normal basaltic magmas. This also applies to the 2.45 Ga dyke suite associated with the Finnish layered intrusions (Guo \& Maier, 2013).

\section{Model 3: pressure increase}

An increase in pressure related to magma replenishment could have triggered sulphide melt saturation throughout the magma chamber (Cawthorn, 2005), but as in Model 1 above, the key challenge is how to achieve rapid and efficient sulphide melt accumulation from a magma body several tens or hundreds of metres in thickness to form the SJ, AP and PV reefs, all of which have widths mostly not exceeding a metre. Pressure changes can potentially explain the formation of the AP and PV anorthosites through pressure release (Cawthorn \& Ashwal, 2009) but as pressure release increases the $S$ solubility of the magma (Mavrogenes \& O'Neill, 1999), the association of sulphides and anorthosite in the AP and PV reefs is inconsistent with the model.

\section{Model 4: in situ contamination}

The PGE reefs could have formed through contamination of replenishing magma pulses with the roof rocks of the magma chamber (Kinnaird et al., 2002). This model would require that replenishing magma pulses intruded the resident magma as a buoyant plume, or that the new magma intruded as a sill between the cumulate pile and the chamber roof. However, the contamination model is inconsistent with our trace element and isotope data that show no significant shift towards more enriched values (as, for example, would be expressed by higher elevated incompatible element contents, LREE/HREE, La/Nb or lower $\varepsilon N d$ ) across the SJ or the other reefs (Figs 15 and 16).

\section{Model 5: fluid flux}

Nicholson \& Mathez (1991) and Boudreau (2008) proposed that the Merensky Reef essentially represents a 
restite formed at a fluid fluxing front. Specifically, the layered anorthosite-chromitite-pyroxenite interval of the Merensky Reef would have formed in response to recrystallization of an initially relatively poorly layered, sulphide-bearing noritic-pyroxenitic proto-cumulate. Recrystallization would have been triggered by late magmatic fluids ascending through the compacting footwall cumulate pile. The fluids caused partial melting of predominantly pyroxene, peritectic crystallization of olivine, and, owing to the expansion of the phase stability fields of chromite and plagioclase, the formation of a basal (restitic) anorthosite layer and one or several chromitite stringers. If the volatile-rich partial melt could not escape from the melting horizon, a pegmatoidal ultramafic layer would also be produced. Within this model, the PGE-rich sulphides are of magmatic origin, but underwent secondary concentration during the partial melting of the proto-cumulate, which facilitated downward percolation of sulphide melt. Fluid-fluxed partial melting of proto-cumulates could potentially also explain the abundant potholes in the Merensky Reef, interpreted as analogues of seafloor pockmarks by Buntin et al. (1985) and Boudreau (1992).

The Penikat reefs share certain lithological features with the Merensky Reef, which could suggest a role for fluid-driven recrystallization in reef formation; namely, the association of PGE with chromitite stringers (SJ, PV reef) and anorthosite layers (AP, PV reefs), the presence of potholes at the base of all reefs, the occurrence of amoeboid (recrystallized) chromite in the footwall of the SJ reef (Halkoaho, 1993), and the localized strong enrichment in incompatible elements $\mathrm{Zr}, \mathrm{P}, \mathrm{Ba}$ and $\mathrm{Cl}$ in the reefs (particularly AP and PV, Fig. 8c).

However, models involving fluid-driven recrystallization of the reefs have failed to gain wide support amongst layered intrusion researchers. The main reason may be that current estimates of the composition of Bushveld parent magmas suggest low volatile contents (0.31 wt \% $\mathrm{H}_{2} \mathrm{O}$ for $\mathrm{B} 1$; Barnes et al., 2010) and cumulates from the Bushveld Complex and other PGE mineralized intrusions such as the Great Dyke and Stillwater, including the reef horizons, are relatively poor in hydrous silicates, mostly at $<1$ modal $\%$. One could argue that in most of the cumulates, volatiles were efficiently expelled during compaction; Karykowski \& Maier (2017) documented up to $5 \%$ phlogopite, as well as abundant alkali feldspar, apatite and zircon, concentrated in pods within about $50 \%$ of analysed LZ samples and argued that intercumulus liquid is highly mobile in the crystallizing cumulates. Maier et al. (2016) suggested that hydrodynamic sorting may result in volatile-rich feldspathic mushes that may act as lubrication planes along which cumulate packages may slide. This in turn may lead to efficient compaction and expulsion of volatilerich residual liquid.

Some studies of the Bushveld and Stillwater complexes proposed that fluids did not just trigger recrystallization of the cumulates, but additionally introduced PGE from the floor cumulates (Boudreau \& McCallum,
1986; Boudreau, 1988; Boudreau \& McCallum, 1992; Wilmore et al., 2000). Petrological arguments against the role of fluids in reef formation have been summarized by Cawthorn et al. (2005). One of the main criticisms is probably that in some intrusions (Bushveld, Portimo) the reefs may be resting just a few tens of metres above the country-rock floor (Iljina \& Hanski, 2005; Van der Merwe, 2007), rendering PGE derivation from the footwall cumulates problematic, unless the footwall was very PGE rich. More importantly, if the PGE were transported by fluids, one would expect to see fractionation between relatively mobile PPGE and largely immobile IPGE, yet the IPGE and PPGE are normally well correlated within the most important PGE reefs, including the Penikat reefs (Fig. 17).

\section{Model 6: emplacement of sills}

The model was initially proposed by Lee and Butcher (1990) Mitchell \& Scoon (2007) for the Merensky Reef and was further developed and applied to both sulphide reefs and chromitites by Latypov et al. (2015). The researchers argued that at the level of the reefs, relatively crystal-poor magma derived from staging chambers injected the semi-consolidated crystal pile in the form of sills. Sulphides were either entrained from a staging chamber or sulphide melt saturation was triggered by in situ mixing, and the high $R$-factors required to generate the high metal tenors of the sulphides were achieved when fertile magma streamed laterally within the sills and past sulphides at the crystallization front. This model is difficult to constrain using chemical data, but Mungall et al. (2016) presented geochronological data to argue that some Bushveld chromitites postdate their host-rocks. At Penikat, the exposure is not good enough to map and analyse sills and apophyses, but high-precision dating of reefs and their host rocks is in preparation.

Model 7: hydrodynamic sorting of crystal mushes Maier \& Barnes (2008) and Maier et al. (2013) proposed that sulphide-bearing crystal mushes at the top of the cumulate pile slump towards the subsiding centre of intrusions, thereby undergoing hydrodynamic sorting to yield layered ultramafic-mafic sequences, consisting of ultramafic and feldspathic cumulates, including anorthosites. The slurries locally intruded into their floor rocks, producing apophyses and sills of chromitite and sulphide-rich silicate rocks. The model is consistent with field and compositional evidence from the Penikat SJ and AP reefs, which are located in intervals characterized by enhanced layering and the presence of magmatic breccias and potholes. The model offers an explanation for the highly efficient concentration of PGE-rich, high $R$-factor sulphides into narrow reefs. Depending on the efficiency of sorting, possibly related to the size and cooling rates of intrusions and the volatile content of the magma, the process may result in the irregular enrichment of chromite and PGE in the reefs 


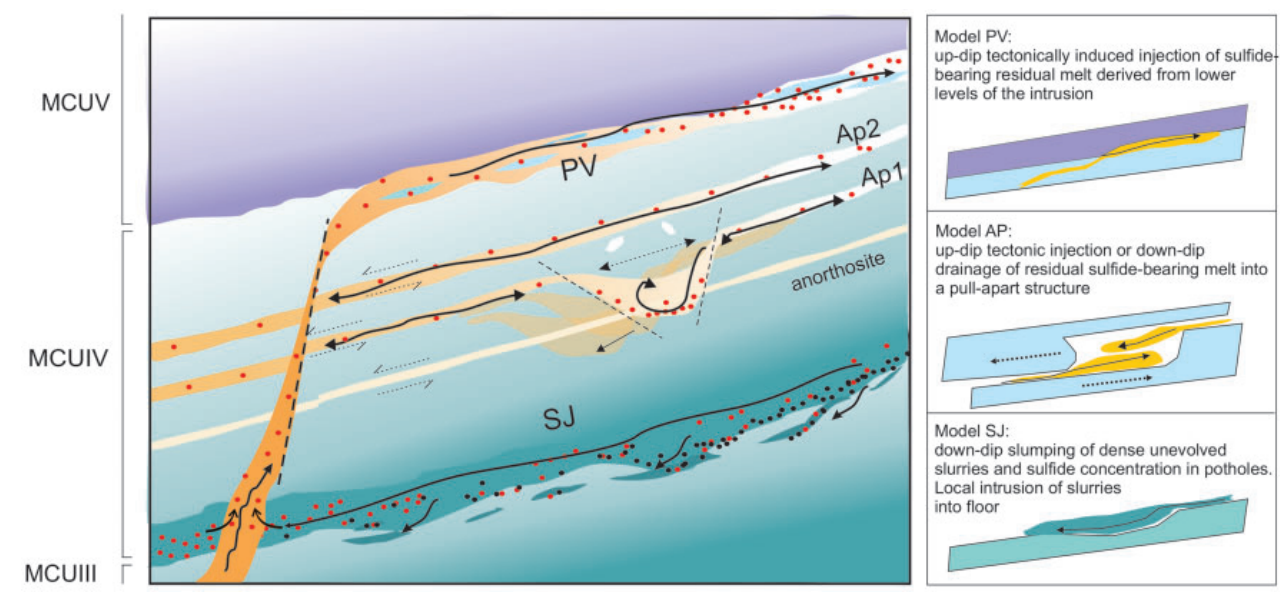

Fig. 21. Schematic model for formation of the Penikat PGE reefs. The SJ reef formed by hydrodynamic sorting of the MCU IV magma influx, leading to concentration of chromite, sulphide and olivine-pyroxene. The abundance of potholes and localized injections into the floor should be noted. The AP reefs formed by hydrodynamic sorting of sulphides emplaced with new magma pulses injecting into MCU IV. This replenishment event also resulted in pull-apart structures expressed in the large AP1 pothole, filled with sulphidic cumulates. The PV reef represents the residual liquid of the SJ reef, displaced upwards owing to intrusion of MCU IV. All three reefs were variably affected by late-stage partial melting induced by late magmatic fluids dammed up below the well-compacted reef rocks, triggering the formation of anorthosite and pegmatoids, notably in the AP and PV reefs. Red dots, sulphide; black dots, chromite; continuous-line arrows, direction of movement of crystal slurries; fine dotted-line arrows, direction of movement of solid rocks; dashed black line, fault.

along-strike, with bonanza-style enrichments in potholes such as within the SJ reef at Kirakkajuppura and the AP1 pothole of the Ala-Penikka block (Fig. 8). The potholes may have formed through a combination of magmatic erosion and faulting facilitating localized collapse of mushes into dilatational (pull-apart) structures. Notably, the abundant pegmatoidal patches associated with the AP pothole and the anorthosite fragments confined to the roof rocks of the pothole suggest that at the time of pull-apart, the AP1 reef was covered by further cumulates (Fig. 21). The hydrodynamic sorting model has been tested by fully scaled tank experiments (Forien et al., 2015), but these need to be extended using non-spherical crystal analogues and variable volatile contents, given that gas bubbles may dramatically alter the flow behaviour of mushes (Lesher \& Spera, 2015).

\section{Model 8: mobilization of PGE-rich magmas from the lower portions of intrusions}

Large layered intrusions are likely to undergo significant tectonism during emplacement and growth (Uken \& Watkeys, 1997). This process could trigger mobilizations of PGE-rich magmas or slurries from within the semi-consolidated cumulate package, ascending through the pile and intruding either as sills within, or as flows on top of the pile. Evidence supporting the model could include features such as intrusive relationships of layers characterized by knife-sharp and transgressive contacts with the hanging-wall and footwall rocks, dykes extending into the roof and floor of layers and possibly containing magmatic breccias, and disequilibrium assemblages characterized by, for example, reversed zoning of minerals. However, the good three- dimensional exposure necessary to make many of these observations is rarely available.

A strong case for sill emplacement can be made for the PV reef in the Penikat intrusion (Fig. 21), characterized by a reversal to relatively un-evolved metal signatures, disequilibrium assemblages characterized by the coexistence of chromite and sulphides showing unfractionated PGE contents with evolved phases such as apatite, alkali feldspar and quartz, strong enrichments in incompatible elements and volatiles relative to the floor and roof rocks, the presence of magmatic breccias, and a knife-sharp contact to the barren roof rocks. These observations are consistent with a model whereby the PV reef formed through intrusion of fractionated, volatile-rich magma along the contact between the largely solidified MCU IV and $\mathrm{V}$. The relatively 'primitive' $\mathrm{Pt} / \mathrm{Pd}, \mathrm{Pd} / \mathrm{lr}$ and $\mathrm{Cu} / \mathrm{Ni}$ ratios of the $\mathrm{PV}$ reef suggest that magma assimilated and entrained sulphide melt from one of the PGE reefs in the lower portion of the intrusion; that is, MCU II or III, or the SJ reef.

\section{SUMMARY AND CONCLUSIONS}

The Penikat intrusion contains several PGE-enriched zones or reefs, analogous to many other PGE mineralized layered intrusions. Poor outcrop and pervasive alteration make interpretation of the data more difficult than elsewhere, and thus much of the evidence has to be gathered from drillcore, complemented by a test pit in the Sompujärvi block and clearing (from lichen) of key outcrops across the intrusion conducted in the 1980s. The evidence suggests that the Penikat reefs formed through a combination of processes. All Penikat rocks have elevated $\mathrm{Cu} / \mathrm{Zr}$, suggesting that the magma was S-saturated or close to S-saturation during much of 
Table 6: Major and trace element and Sm-Nd isotope data for five types of granitoids used in Fig. 20

\begin{tabular}{|c|c|c|c|c|c|}
\hline $\begin{array}{l}\text { Sample: } \\
\text { Region: } \\
\text { Area: } \\
\text { Rock type: }\end{array}$ & $\begin{array}{c}1 \\
\text { A2126 } \\
\text { Eastern Finland } \\
\text { Surmansuo } \\
\text { porphyritic granite }\end{array}$ & $\begin{array}{c}2^{*} \\
\text { R4, } 93001822 \\
\text { Pudasjärvi } \\
\text { Runkaus } \\
\text { granite }\end{array}$ & $\begin{array}{c}3 \\
\text { A1906 } \\
\text { Suomussalmi } \\
\text { Taka-aho } \\
\text { trondhjemite }\end{array}$ & $\begin{array}{c}4 \\
\text { K13 } \\
\text { Russian Karelia } \\
\text { Vodla Block } \\
\text { tonalite }\end{array}$ & $\begin{array}{c}5 \\
\text { A1602 } \\
\text { Pudasjärvi } \\
\text { Siurua } \\
\text { trondhjemite gneiss }\end{array}$ \\
\hline $\mathrm{SiO}_{2}$ & 71.82 & $67 \cdot 2$ & $72 \cdot 30$ & 68.5 & $70 \cdot 30$ \\
\hline $\mathrm{TiO}_{2}$ & 0.34 & 0.467 & 0.28 & 0.37 & 0.45 \\
\hline $\mathrm{Al}_{2} \mathrm{O}_{3}$ & 14.08 & $15 \cdot 8$ & 14.80 & $16 \cdot 6$ & $15 \cdot 6$ \\
\hline $\mathrm{FeO}_{\mathrm{t}}$ & 1.99 & $3 \cdot 34$ & 2.60 & $3 \cdot 26$ & 2.33 \\
\hline $\mathrm{MnO}$ & 0.02 & 0.042 & 0.04 & 0.05 & 0.020 \\
\hline $\mathrm{MgO}$ & 0.79 & 1.24 & 0.64 & 1.32 & 0.92 \\
\hline $\mathrm{CaO}$ & 2.03 & $2 \cdot 3$ & 2.78 & 3.94 & $3 \cdot 17$ \\
\hline $\mathrm{Na}_{2} \mathrm{O}$ & $4 \cdot 16$ & $4 \cdot 16$ & 4.57 & $4 \cdot 74$ & $4 \cdot 48$ \\
\hline $\mathrm{K}_{2} \mathrm{O}$ & 3.89 & $4 \cdot 2$ & 1.85 & 1.01 & 1.83 \\
\hline $\mathrm{P}_{2} \mathrm{O}_{5}$ & 0.13 & 0.229 & 0.12 & $0 \cdot 12$ & 0.03 \\
\hline $\mathrm{Ba}$ & 1115 & 2817 & 524 & n.a. & 503 \\
\hline $\mathrm{Bi}$ & n.a. & $<0.04$ & $<30$ & n.a. & n.a. \\
\hline $\mathrm{Cl}$ & 128.00 & 110 & 121 & n.a. & 170.00 \\
\hline Co & 4.6 & $7 \cdot 6$ & 4.0 & n.a. & 5.6 \\
\hline $\mathrm{Cr}$ & $<30$ & 25 & $<30$ & 15 & $<30$ \\
\hline $\mathrm{Cu}$ & n.a. & $<17$ & $<20$ & $20 \cdot 1$ & $<5$ \\
\hline $\mathrm{Ga}$ & 23 & 28 & 26 & $20 \cdot 2$ & 15 \\
\hline $\mathrm{Hf}$ & n.a. & 3.82 & $3 \cdot 42$ & $4 \cdot 11$ & 6.90 \\
\hline Mo & n.a. & $<2 \cdot 6$ & $<10$ & n.a. & n.a. \\
\hline $\mathrm{Nb}$ & 4.89 & 4.05 & 4.59 & $4 \cdot 1$ & $5 \cdot 20$ \\
\hline $\mathrm{Ni}$ & 29 & $<14$ & $<20$ & 5 & 8 \\
\hline $\mathrm{Pb}$ & 24.0 & 35 & $<30$ & n.a. & 32 \\
\hline $\mathrm{Rb}$ & 159.0 & 91 & $67 \cdot 1$ & n.a. & 57 \\
\hline $\mathrm{S}$ & 32 & $<70$ & $<60$ & n.a. & n.a. \\
\hline $\mathrm{Sc}$ & $5 \cdot 10$ & n.a. & 4.02 & 6.92 & 3.6 \\
\hline $\mathrm{Sr}$ & 370 & 854 & 248 & n.a. & 311 \\
\hline Ta & 0.42 & n.a. & 0.40 & n.a. & $<0.2$ \\
\hline Th & 18.59 & n.a. & $7 \cdot 24$ & $2 \cdot 8$ & 46 \\
\hline U & 3.60 & n.a. & 0.94 & 0.256 & 2 \\
\hline V & 31.5 & 44.5 & $19 \cdot 8$ & 58 & 32 \\
\hline $\mathrm{Y}$ & 6.03 & $7 \cdot 31$ & $7 \cdot 16$ & 6.92 & 7.5 \\
\hline $\mathrm{Zn}$ & 55 & 70 & 65 & n.a. & 22 \\
\hline $\mathrm{Zr}$ & 188 & 162 & 127 & 151 & 294 \\
\hline La & 52.0 & 74.4 & 23.5 & 23.7 & 123.0 \\
\hline $\mathrm{Ce}$ & 95.9 & 131 & $42 \cdot 9$ & 39.4 & 213.0 \\
\hline $\mathrm{Pr}$ & $10 \cdot 1$ & $13 \cdot 1$ & 4.4 & 4.65 & $22 \cdot 2$ \\
\hline $\mathrm{Nd}$ & 34.6 & $41 \cdot 1$ & $13 \cdot 8$ & $16 \cdot 2$ & $75 \cdot 8$ \\
\hline $\mathrm{Sm}$ & 5.01 & 4.94 & 2.06 & $2 \cdot 41$ & $10 \cdot 0$ \\
\hline $\mathrm{Eu}$ & 1.05 & 1.26 & 0.51 & 0.811 & 1.35 \\
\hline $\mathrm{Gd}$ & 3.42 & 3.53 & 2.01 & 1.97 & 6.77 \\
\hline $\mathrm{Tb}$ & 0.37 & & 0.27 & 0.242 & 0.59 \\
\hline Dy & 1.69 & 1.34 & 1.30 & $1 \cdot 34$ & 1.90 \\
\hline Ho & 0.23 & 0.22 & 0.23 & 0.26 & 0.27 \\
\hline Er & 0.53 & 0.55 & 0.63 & 0.739 & 0.60 \\
\hline Tm & 0.07 & 0.08 & $<0.10$ & 0.106 & $<0.1$ \\
\hline $\mathrm{Yb}$ & 0.48 & 0.49 & 0.62 & 0.695 & 0.55 \\
\hline $\mathrm{Lu}$ & 0.1 & 0.07 & $<0.10$ & 0.105 & $<0.1$ \\
\hline \multicolumn{6}{|l|}{ Isotopic data } \\
\hline Sm & 4.41 & $4 \cdot 24$ & $2 \cdot 38$ & 2.41 & $10 \cdot 44$ \\
\hline $\mathrm{Nd}$ & $30 \cdot 76$ & 34.08 & 15.09 & $16 \cdot 23$ & $78 \cdot 18$ \\
\hline${ }^{147} \mathrm{Sm} /{ }^{144} \mathrm{Nd}$ & 0.0866 & 0.0752 & 0.0955 & 0.08975 & 0.0807 \\
\hline${ }^{143} \mathrm{Nd} /{ }^{144} \mathrm{Nd}$ & 0.510707 & 0.510404 & 0.510731 & 0.510464 & 0.510025 \\
\hline$\varepsilon \mathrm{Nd}(2440 \mathrm{Ma})$ & $-3 \cdot 2$ & -5.6 & -5.5 & $-9 \cdot 0$ & -14.7 \\
\hline Age (Ma) & 2695 & 2700 & 2824 & 3213 & 3500 \\
\hline
\end{tabular}

References: 1, Mikkola et al. (2014); 2, Huhma et al. (2012), Geological Survey of Finland (GTK); 3, Mikkola et al. (2011); 4, Puchtel et al. (2016); 5, Mutanen \& Huhma (2003), Huhma et al. (2012).

*For 2, we used isotopic data on sample R4, major and trace elements on sample 93001822 (GTK's lithogeochemistry database).

the crystallization history. All reefs occur in intervals of enhanced layering and compositional reversals, suggesting that magma replenishment played an important role in reef formation. Whether mixing of magmas and temporary increases in pressure resulting from replenishment contributed to driving the magmas to sulphide saturation remains unclear. Although all Penikat reefs have been traced along much of the strike length of the intrusion, they show less continuity, albeit broadly similar overall grade, compared with, for example, the Bushveld or Great Dyke reefs, possibly owing to faster cooling as a result of the relatively smaller size of the 
intrusion. Bonanza-style PGE enrichments in SJ and AP potholes suggest that hydrodynamic sorting was important in reef formation. The PV reef is unusual in that it possibly formed from magmas that cannibalized sulphides from the lower portion of the intrusion and then intruded into, rather than flowed on top of the cumulate package. All three major PGE reefs were affected by late magmatic recrystallization triggered by fluids or volatile-rich melts ascending during cooling and compaction of the footwall rocks. This was of relatively minor importance in the case of the SJ reef, but was more significant in the AP and PV reefs, generating abundant pegmatoidal pods, and localized pods and stringers of chromitite. However, in none of the reefs is there evidence for mobilization of PGE by fluids.

\section{ACKNOWLEDGEMENTS}

Yann Lahaye, Hugh O'Brien, Leena Järvinen and Arto Pulkkinen are thanked for assistance during ICP-MS analyses. Constructive reviews by Alan Boudreau, Jim Miller and Markku Iljina provided much added insight.

\section{FUNDING}

W.M.'s research is supported by the Renlund Foundation and E. Hanski's research by an Academy of Finland grant (No. 281859).

\section{SUPPLEMENTARY DATA}

Supplementary data for this paper are available at Journal of Petrology online.

\section{REFERENCES}

Alapieti, T. T. \& Halkoaho, T. A. A. (1995). Cryptic variation of augite in the Penikat layered intrusion, northern Finland, with reference to megacyclic units and PGE-enriched zones. Mineralogy and Petrology 54, 11-24.

Alapieti, T. T. \& Lahtinen, J. J. (1986). Stratigraphy, petrology and platinum-group element mineralization of the early Proterozoic Penikat layered intrusion, Northern Finland. Economic Geology 81, 1126-1136.

Alapieti, T. T. \& Lahtinen, J. J. (1989). Early Proterozoic layered intrusions in the northeastern part of the Fennoscandian Shield. In: Alapieti, T. (ed.) 5th International Platinum Symposium, Guide to the Post-Symposium Field Trip, Geological Survey of Finland, Guide 29, 3-41.

Alapieti, T. T. \& Lahtinen, J. J. (2002). Platinum-group element mineralization in layered intrusions of northern Finland and the Kola peninsula. In: Cabri, L. J. (ed.) The Geology, Geochemistry, Mineralogy and Mineral Beneficiation of Platinum-Group Elements. Canadian Institute of Mining, Metallurgy and Petroleum, Special Volume 54.

Alapieti, T. T., Kujanpää, J., Lahtinen, J. J. \& Papunen, H. (1989). The Kemi stratiform chromitite deposit, northern Finland. Economic Geology 84, 1057-1077.

Alapieti, T. T., Filén, B. A., Lahtinen, J. J., Lavrov, M. M., Smolkin, V. F. \& Voitsekhovsky, S. N. (1990). Early
Proterozoic layered intrusions in the northeastern part of the Fennoscandian Shield. Mineralogy and Petrology 42, 1-22.

Amelin, Y. V. \& Semenov, V. S. (1996). Nd and Sr isotopic geochemistry of mafic layered intrusions in the eastern Baltic shield: implications for the evolution of Paleoproterozoic continental mafic magmas. Contributions to Mineralogy and Petrology 124, 255-272.

Amelin, Y. V., Heaman, L. M. \& Semenov, V. S. (1995). U-Pb geochronology of layered mafic intrusions in the eastern Baltic Shield; implications for the timing and duration of Paleoproterozoic continental rifting. Precambrian Research 75, 31-46.

Andersen, J. C. $\varnothing$., Thalhammer, O. A. R. \& Schoenberg, R. (2006). Platinum-group element and Re-Os isotope variations of the high-grade Kilvenjärvi platinum-group element deposit, Portimo Layered Igneous Complex, Finland. Economic Geology 101, 159-177.

Andersen, T., Griffin, W. L., Jackson, S. E., Knudsen, T.-L. \& Pearson, N. J. (2004). Mid-Proterozoic magmatic arc evolution at the southwest margin of the Baltic Shield. Lithos 73, 289-318.

Arguin, J.-P., Pagé, P., Barnes, S.-J., Yu, S.-Y. \& Song, X.-Y. (2016). The effect of chromite crystallization on the fractionation of osmium, iridium, ruthenium and rhodium in picritic magmas: an example from the Emeishan Large Igneous Province, south-western China. Journal of Petrology 57, 1019-1048.

Barnes, S. J. (1989). Are Bushveld U-type parent magmas boninites or contaminated komatiites? Contributions to Mineralogy and Petrology 101, 447-457.

Barnes, S.-J. \& Maier, W. D. (1999). The fractionation of $\mathrm{Ni}, \mathrm{Cu}$ and the noble metals in silicate and sulfide liquids. In: Keays, R. R., Lesher, C. M., Lightfoot, P. C. \& Farrow, C. E. G. (eds) Magmatic Ore Deposits and their Application in Mineral Exploration. Geological Association of Canada, Short Course Volume 13, 69-106.

Barnes, S.-J., Maier, W. D. \& Curl, E. (2010). Composition of the marginal rocks and sills of the Rustenburg Layered Suite, Bushveld Complex, South Africa: implications for the formation of the platinum-group element deposits. Economic Geology 105, 1491-1511.

Boudreau, A. E. (1992). Volatile fluid overpressure in layered intrusions and the formation of potholes. Australian Journal of Earth Sciences 39, 277-287.

Boudreau, A. E. (2008). Modeling the Merensky Reef, Bushveld Complex, Republic of South Africa. Contributions to Mineralogy and Petrology 156, 431-437.

Boudreau, A. E. \& McCallum, I. S. (1986). Investigations of the Stillwater Complex. Part III. The Picket Pin Pt-Pd deposit. Economic Geology 81, 1953-1975.

Boudreau, A. E. \& McCallum, I. S. (1992). Concentration of platinum-group elements by magmatic fluids in layered intrusions. Economic Geology 87, 1830-1848.

Buntin, T. J., Grandstaff, D. E., Ulmer, G. C. \& Gold, D. P. (1985). A pilot study of geochemical and redox relationships between potholes and adjacent Merensky Reef on the Bushveld Complex. Economic Geology 80, 975-987.

Campbell, I. H., Naldrett, A. J. \& Barnes, S. J. (1983). A model for the origin of the platinum-rich sulfide horizons in the Bushveld and Stillwater Complexes. Journal of Petrology 24, 133-165.

Cawthorn, R. G. (2005). Pressure fluctuations and the formation of the PGE rich Merensky and chromitite reefs, Bushveld Complex. Mineralium Deposita 40, 231-235.

Cawthorn, R. G. \& Ashwal, L. D. (2009). Origin of anorthosite and magnetite layers in the Bushveld Complex, constrained by major element compositions of plagioclase. Journal of Petrology50, 1607-1637. 
DePaolo, D. J. (1981). Neodymium isotopes in the Colorado Front Range and crust-mantle evolution in the Proterozoic. Nature 291, 193-687.

Eales, H. V. \& Reynolds, I. M. (1986). Cryptic variations within chromitites of the upper critical zone, northwestern Bushveld Complex. Economic Geology 81, 1056-1066.

Eales, H. V., Field, M., de Klerk, W. J. \& Scoon, R. N. (1988). Regional trends of chemical variation and thermal erosion in the Upper Critical Zone, western Bushveld Complex. Mineralogical Magazine 52, 63-79.

Eerola, P., Reino, J., Vaajoensuu, K. \& Seppänen, A. (1990). On the potential to utilize the PGE-Au-Cu-Ni occurrences in the Kivalot area. Outokumpu Mining Services, Report 090/2543,2544,3613/90 (in Finnish).

Ernst, R. \& Bleeker, W. (2010). Large igneous provinces (LIPs), giant dyke swarms, and mantle plumes: significance for breakup events within Canada and adjacent regions from $2.5 \mathrm{Ga}$ to the Present. Canadian Journal of Earth Sciences 47, 695-739.

Forien, M., Tremblay, J., Barnes, S.-J., Burgisser, A. \& Page, P. (2015). The role of viscous particle segregation in forming chromite layers from slumped crystal slurries: insights from analogue experiments. Journal of Petrology 56, 2425-2444.

Guo, F. \& Maier, W. D. (2013). Geochemistry of $\sim 2.45$ Ga mafic dykes in Northern Finland: constraints on the origin of PGE mineralization in coeval layered intrusions. 12th SGA Biennial Meeting, Uppsala, Sweden.

Halkoaho, T. A. A. (1989). Ala-Penikka platinum mineralisations in the Penikat layered intrusion (Ala-Penikan platinametallimineralisaatiot Penikkain kerrosintruusiossa). Report 2 of the PGE research project, University of Oulu, 173 pp. (in Finnish).

Halkoaho, T. A. A. (1993). The Sompujärvi and Ala-Penikka PGE reefs of the Penikat Layered Intrusion, northern Finland-implications for PGE-reef forming processes. Acta Universitatis Ouluensis, Series A, Scientiae Rerum Naturalium 249, 122 pp.

Halkoaho, T. A. A., Alapieti, T. T. \& Lahtinen, J. J. (1989a). The Sompujärvi PGE mineralization in the Penikat layered intrusion, Northern Finland. In: Alapieti, T. (ed.) 5th International Platinum Symposium, Guide to the Post-Symposium Field Trip, Geological Survey of Finland, Guide 29, 71-92.

Halkoaho, T. A. A., Alapieti, T. T. \& Lahtinen, J. J. (1989b). The Ala-Penikka PGE mineralizations in the Penikat layered intrusion, Northern Finland. In: Alapieti, T. (ed.) 5th International Platinum Symposium, Guide to the Post-Symposium Field Trip, Geological Survey of Finland, Guide 29, 93-122.

Halkoaho, T. A. A., Alapieti, T. T. \& Lahtinen, J. J. (1990a). The Sompujärvi PGE reef in the Penikat layered intrusion, northern Finland. Mineralogy and Petrology 42, 39-55.

Halkoaho, T. A. A., Alapieti, T. T., Lahtinen, J. J. \& Lerssi, J. M. (1990b). The Ala-Penikka PGE reefs in the Penikat layered intrusion, northern Finland. Mineralogy and Petrology 42, 23-38.

Halkoaho, T. A. A., Alapieti, T. \& Huhtelin, T. (2005). The Sompujärvi, Ala-Penikka and Pasivaara PGE reefs in the Penikat layered intrusion, northern Finland. In: Alapieti, T. T. \& Kärki, A. J. (eds) Field Trip Guidebook. Geological Survey of Finland, Guide 51a, 110 pp.

Hanski, E. (2012). Evolution of the Palaeoproterozoic $(2.50-1.95 \mathrm{Ga})$ non-orogenic magmatism in the eastern part of the Fennoscandian Shield. In: Melezhik, V. A., Prave, A. R., Fallick, A. E., Kump, L. R., Strauss, H., Lepland, A. \& Hanski, E. J. (eds) Reading the Archive of Earth's Oxygenation, Volume 1: The Palaeoproterozoic of Fennoscandia as
Context for the Fennoscandian Arctic Russia-Drilling Earth Project. Berlin: Springer, doi:10.1007/978-3-642-29682-6_6.

Hanski, E. \& Huhma, H. (2005). Central Lapland Greenstone Belt. In: Lehtinen, M., Nurmi, P. \& Rämö, O. T. (eds) Precambrian Bedrock of Finland-Key to the Evolution of the Fennoscandian Shield. Amsterdam: Elsevier, pp. 139-194.

Hanski, E. J. \& Melezhik, V. A. (2012). Litho- and chronostratigraphy of the Karelian Formations. In: Melezhik, V. A., Prave, A. R., Hanski, E. J., Fallick, A. E., Lepland, A., Kump, L. R. \& Strauss, H. (eds) Reading the Archive of Earth's Oxygenation. Volume 1: The Palaeoproterozoic of Fennoscandia as Context for the Fennoscandian Arctic Russia-Drilling Early Earth Project. Berlin: Springer, pp. 39-110.

Hanski, E., Walker, R. J., Huhma, H. \& Suominen, I. (2001). The Os and $\mathrm{Nd}$ isotopic systematics of the $2.44 \mathrm{Ga}$ Akanvaara and Koitelainen mafic layered intrusions in northern Finland. Precambrian Research 109, 73-102.

Heltz, R. (1985). Compositions of fine-grained mafic rocks from sills and dikes associated with the Stillwater Complex. In: The Stillwater Complex, Montana: Geology and Guide, Montana Bureau of Mines and Geology, Special Publication 92, 97-117.

Holwell, D. A., McDonald, I. \& Butler, I. B. (2010). Precious metal enrichment in the Platreef, Bushveld Complex, South Africa: evidence from homogenized magmatic sulfide melt inclusions. Contributions to Mineralogy and Petrology doi: 10.1007/s00410-010-0577-0.

Huhma, H., Cliff, R. A., Perttunen, V. \& Sakko, M. (1990). Sm-Nd and $\mathrm{Pb}$ isotopic study of mafic rocks associated with early Proterozoic continental rifting: the Peräpohja schist belt in northern Finland. Contributions to Mineralogy and Petrology 104, 369-379.

Huhma, H., Mänttäri, I., Peltonen, P., Kontinen, A., Halkoaho, T., Hanski, E., Hokkanen, T., Hölttä, P., Juopperi, H., Konnunaho, J., Layahe, Y., Luukkonen, E., Pietikäinen, K., Pulkkinen, A., Sorjonen-Ward, P., Vaasjoki, M. \& Whitehouse, M. (2012). The age of the Archaean greenstone belts in Finland. Geological Survey of Finland, Special Paper 54, 74-175.

Huhma, H., Hanski, E., Kontinen, A., Vuollo, J., Mänttäri, I. \& Lahaye, Y. (2018). Sm-Nd and U-Pb isotope geochemistry of the Palaeoproterozoic mafic magmatism in eastern and northern Finland. Geological Survey of Finland, Bulletin 405, 150.

Huhtelin, T. (1989). Paasivaaran platinamineralisaatio Penikkain kerrosintruusiossa. Report 1 of the PGE Research Project, University of Oulu, $70 \mathrm{pp}$. (in Finnish).

Huhtelin, T. A., Alapieti, T. T. \& Lahtinen, J. J. (1989a). The Paasivaara PGE mineralization in the Penikat layered intrusion, Northern Finland. In: Alapieti, T. (ed.) 5th International Platinum Symposium, Guide to the Post-Symposium Field Trip, Geological Survey of Finland, Guide 29, 123-144.

Huhtelin, T. A., Alapieti, T. T., Lahtinen, J. J. \& Lerssi, J. (1989b). Megacyclic Units I, II and II in the Penikat layered intrusion. In: Alapieti, T. (ed.) 5th International Platinum Symposium, Guide to the Post-Symposium Field Trip, Geological Survey of Finland, Guide 29.

Huhtelin, T. A., Alapieti, T. T. \& Lahtinen, J. J. (1990). The Paasivaara PGE reefs in the Penikat layered intrusion, northern Finland. Mineralogy and Petrology 42, 57-70.

Iljina, M. (1994). The Portimo Layered Igneous Complex with emphasis on diverge sulphide and platinum-group element deposits. Acta Universitatis Ouluensis, Series A, Scientiae Rerum Naturalium 258, 158 pp. 
Iljina, M. \& Hanski, E. (2005). Layered mafic intrusions of the Tornio-Näränkävaara Belt. In: Lehtinen, M., Nurmi, P. A. \& Rämö, O. T. (eds) Precambrian Geology of Finland-Key to the Evolution of the Fennoscandian Shield. Amsterdam: Elsevier, pp. 101-138.

Iljina, M. \& Salmirinne, H. (2011). Suhanko seismic reflection profile and integrated geological-geophysical model of the Portimo area. Geological Survey of Finland, Report of Investigation 189.

Irvine, T. N. (1975). Crystallization sequences in the Muskox intrusion and other layered intrusions-Il. Origin of chromitite layers and similar deposits of other magmatic ores. Geochimica et Cosmochimica Acta 39, 991-1020.

Irvine, T. N. (1982). Terminology for layered intrusions. Journal of Petrology 23, 127-162.

Jackson, S. E., Pearson, N. J., Griffin, W. L. \& Belousova, E. A. (2004). The application of laser ablation-inductively coupled plasma-mass spectrometry to in-situ $\mathrm{U}-\mathrm{Pb}$ zircon geochronology. Chemical Geology 211, 47-69.

Karinen, T. (2010). The Koillismaa Intrusion, northeastern Finland-evidence for PGE reef forming processes in the layered series. Geological Survey of Finland Bulletin 404, $176 \mathrm{pp}$.

Karinen, T., Hanski, E. \& Taipale, A. (2015). The Mustavaara Fe-Ti-V oxide deposit. In: Maier, W., O'Brien, H. \& Lahtinen, R. (eds) Mineral Deposits of Finland. Amsterdam: Elsevier, pp. 179-194.

Karykowski, B. \& Maier, W. D. (2017). Microtextural characterisation of the Lower Zone in the western limb of the Bushveld Complex, South Africa: Evidence for extensive melt migration within a sill complex. Contributions to Mineralogy and Petrology 172, 60.

Kukkonen, I., Heikkinen, P., Elo, S., Heinonen, S. \& Laitinen, J. \& HIRE Working Group of the Geological Survey of Finland (2010). HIRE Seismic Reflection Survey in the Sompujärvi PGE Exploration Area, Northern Finland. Geological Survey of Finland, Report Q23/2010/23, 43 pp.

Latypov, R., Chistyakova, S., Page, A. \& Hornsey, R. (2015). Field evidence for the in situ crystallization of the Merensky Reef. Journal of Petrology 56, 2341-2372.

Lee, C. A. \& Butcher, A. R. (1990). Cyclicity in the Sr isotope stratigraphy through the Merensky and Bastard Reefs, Atok Section, eastern Bushveld Complex. Economic Geology 85, 877-883.

Lerssi, J. (1990). Geophysical investigations. In: Alapieti, T., Halkoaho, T., Huhtelin, T., Iljina, M. \& Lerssi, J. (eds) Final Report of the Peräpohja Platinum Project. PGE Research Project, University of Oulu, Report 3, pp. 122-149 (in Finnish).

Li, C. \& Ripley, E. M. (2005). Empirical equations to predict the sulfide content of mafic magmas at sulfide saturation and applications to magmatic sulfide deposits. Mineralium Deposita 40, 218-230.

Linkermann, S. A. (2011). Emplacement of the $2.44 \mathrm{Ga}$ ultramafic layered Kemi intrusion, Finland: PGE, geochemical and $\mathrm{Sm}-\mathrm{Nd}$ isotopic implications. MSc thesis, Rhodes University, Grahamstown, South Africa.

Ludwig, K. R. (2003). User's manual for Isoplot/Ex, Version 3.00. A geochronological toolkit for Microsoft Excel. Berkeley Geochronology Center Special Publication 4.

Maier, W. D. \& Barnes, S.-J. (2008). Platinum-group elements in the UG1 and UG2 chromitites and the Bastard reef at Impala platinum mine, western Bushveld Complex. South African Journal of Geology 111, 159-176.

Maier, W. D. \& Eales, H. V. (1997). Correlation within the UG2-Merensky Reef interval of the Western Bushveld Complex, based on geochemical, mineralogical and petrological data. Geological Survey of South Africa Bulletin 120, $56 \mathrm{pp}$.

Maier, W. D., Peltonen, P., McDonald, I., Barnes, S. J., Barnes, S.-J., Hatton, C. \& Viljoen, F. (2012). The platinum-group element budget of the Kaapvaal and Karelian sub-continental lithospheric mantle: implications for mantle evolution. Chemical Geology 302-303, 119-135.

Maier, W. D., Barnes, S.-J. \& Groves, D. I. (2013). The Bushveld Complex, South Africa: formation of platinum-palladium, chrome and vanadium-rich layers via hydrodynamic sorting of a mobilized cumulate slurry in a large, relatively slowly cooling, subsiding magma chamber. Mineralium Deposita 48, 1-56.

Maier, W. D., Barnes, S.-J. \& Karykowski, B. T. (2016). A chilled margin of komatiite and Mg-rich basaltic andesite in the western Bushveld Complex, South Africa. Contributions to Mineralogy and Petrology doi:10.1007/s00410-016-1257-5.

McDonald, I. \& Viljoen, K. S. (2006). Platinum-group element geochemistry of mantle eclogites: a reconnaissance study of xenoliths from the Orapa kimberlite, Botswana. Transactions of the Institution of Mining and Metallurgy 115, 81-93.

Mikkola, P., Huhma, H., Heilimo, E. \& Whitehouse, M. (2011). Archean crustal evolution of the Suomussalmi district as part of the Kianta Complex, Karelia: Constraints from geochemistry and isotopes of granitoids. Lithos 125, 287-307.

Mikkola, P., Heilimo, E. \& Huhma, H. (2014). Relationships between sanukitoids and crust-derived melts and their implications for the diversity of Neoarchaean granitoids: a case study from Surmansuo and nearby areas, Eastern Finland. Bulletin of the Geological Society of Finland 86, 23-40.

Naldrett, A. J. \& von Gruenewaldt, G. (1989). Association of platinum-group elements with chromitite in layered intrusions and ophiolite complexes. Economic Geology 84, 180-187.

Naldrett, A. J., Wilson, A., Kinnaird, J. \& Chunnett, G. (2009). PGE tenor and metal ratios within and below the Merensky Reef, Bushveld Complex: implications for its genesis. Journal of Petrology 50, 625-659.

Nicholson, D. M. \& Mathez, E. A. (1991). Petrogenesis of the Merensky Reef in the Rustenburg section of the Bushveld Complex. Contributions to Mineralogy and Petrology 107, 293-309.

Perttunen, V. \& Vaasjoki, M. (2001). U-Pb geochronology of the Peräpohja Schist Belt, northwestern Finland. In: Vaasjoki, M. (ed.) Radiometric Age Determinations from Finnish Lapland and their Bearing on the Timing of Precambrian Volcano-sedimentary Sequences. Geological Survey of Finland, Special Paper 33, 45-84.

Pripachkin, P. V., Rundkvist, T. V., Miroshnikova, Y. A., Chernyavsky, A. V. \& Borisenko, E. S. (2018). Geological structure and ore mineralization of the South Sopchinsky massif (Monchegorsk area, Kola Peninsula, Russia). Mineralium Deposita, in press.

Puchtel, I. S., Haase, K. M., Hofmann, A. W., Chauvel, C. Kulikov, V. S., Garbe-Schönberg, C. D. \& Nemchin, A. A. (1997). Petrology and geochemistry of crustally contaminated komatiitic basalts from the Vetreny Belt, southeastern Baltic Shield: evidence for an early Proterozoic mantle plume beneath rifted Archean continental lithosphere. Geochimica et Cosmochimica Acta 61, 1205-1222.

Puchtel, I. S., Touboul, M., Blichert-Toft, J., Walker, R. J., Brandon, A. D., Nicklas, R. W., Kulikov, V. S. \& Samsonov, A V. (2016). Lithophile and siderophile element systematics of Earth's mantle at the Archean-Proterozoic boundary: evidence from 2.4 Ga komatiites. Geochimica et Cosmochimica Acta 180, 227-255. 
Puritch, E., Ewert, W., Brown, F. H., Rickard, J. \& King, D. (2007). Techical report, mineral resource estimate, and preliminary economic assessment (scoping study) of the Suhanko project northern Finland NI-43-101 \& 43-101F1, Technical Report and Scoping Study, Report 135.

Richard, P., Shimizu, N. \& Allègre, C. J. (1976). ${ }^{143} \mathrm{Nd} /{ }^{146} \mathrm{Nd}$, a natural tracer: an application to oceanic basalts. Earth and Planetary Science Letters 31, 269-278.

Rosa, D. R. N., Finch, A. A., Andersen, T. \& Inverno, C. M. C. (2009). U-Pb geochronology and $\mathrm{Hf}$ isotope ratios of magmatic zircons from the Iberian pyrite belt. Mineralogy and Petrology 95, 47-69.

Saini-Eidukat, B., Alapieti, T. T., Thalhammer, O. A. R. \& Iljina, M. J. (1997). Siliceous, high-magnesian parental magma compositions of the PGE-rich Early Paleoproterozoic layered intrusion belt of northern Finland. In: Pei, R. (ed.) Proceedings of the 30th International Geological Congress, Beijing, China, 4-14 August 1996. Vol. 9, Energy and Mineral Resources for the 21st Century, Geology of Mineral Deposits, Mineral Economics. VSP, pp. 177-197.

Savard, D., Bedard, L. P. \& Barnes, S.-J. (2006). TCF selenium preconcentration in geological materials for determination at sub $\mu \mathrm{g} \mathrm{g}^{-1}$ with INAA (Se/TCF-INAA). Talanta 70, 566-571.

Savard, D., Barnes, S.-J. \& Meisel, T. (2010). Comparison between nickel-sulfur fire assay Te co-precipitation and isotope dilution with high-pressure asher acid digestion for the determination of PGE Re and gold. Geostandards and Geoanalytical Research 34, 281-291.

Sharpe, M. R. (1981). The chronology of magma influxes to the eastern compartment of the Bushveld Complex, as exemplified by its marginal border group. Journal of the Geological Society, London 138, 307-326.

Stacey, J. S. \& Kramers, J. D. (1975). Approximation of terrestrial lead isotope evolution by a two-stage model. Earth and Planetary Science Letters 26, 207-221.

Sun, S.-S. \& McDonough, W. F. (1989). Chemical and isotopic systematics of oceanic basalts: implications for mantle composition and processes. In: Saunders, A. D. \& Norry, M. J. (eds) Magmatism in the Ocean Basins. Geological Society, London, Special Publications 42, 313-345.

Turner, A. R., Wolfgram, D. \& Barnes, S. J. (1985). Geology of the Stillwater county sector of the J-M Reef, including the Minneapolis adit. In: Czamanske, G. K. \& Zientek, M. L. (eds)
Stillwater Complex, Montana: Geology and Guide. Montana Bureau of Mines and Geology, Special Publication 92, 210-231.

Uken, R. \& Watkeys, M. K. (1997). Diapirism initiated by the Bushveld Complex, South Africa. Geology 25, 723-726.

Van der Merwe, M. (2007). The occurrence of the critical zone along the exposed southeastern sector of the eastern Bushveld Complex. South African Journal of Geology 110, 617-630.

Vuollo, J. (1994). Palaeoproterozoic basic igneous events in Eastern Fennoscandian shield between 2.45 and $1.97 \mathrm{Ga}$, studied by means of mafic dyke swarms and ophiolites in Finland, $47+67 \mathrm{pp}$.

Vuollo, J. \& Huhma, H. (2005). Paleoproterozoic mafic dykes in NE Finland. In: Lehtinen, M., Nurmi, P. A. \& Rämö, O. T. (eds) Precambrian Geology of Finland-Key to the Evolution of the Fennoscandian Shield. Amsterdam: Elsevier, pp. 195-236.

Wagner, P. A. (1929). The Platinum Deposits and Mines of South Africa. Edinburgh: Oliver \& Boyd, $326 \mathrm{pp}$.

Wasserburg, G. J., Jacobsen, S. B., DePaolo, D. J., McCulloch, M. T. \& Wen, T. (1981). Precise determination on $\mathrm{Sm} / \mathrm{Nd}$ ratios, $\mathrm{Sm}$ and $\mathrm{Nd}$ isotopic abundances in standard solutions. Geochimica et Cosmochimica Acta 45, 2311-2324.

Weis, D., Kieffer, B., Maerschalk, C., Barling, J., de Jong, J., Williams, G. A., Hanano, D., Pretorius, W., Mattielli, N., Scoates, J. S., Goolaerts, A., Friedman, R. M. \& Mahoney, J. B. (2006). High-precision isotopic characterization of USGS reference materials by TIMS and MC-ICP-MS. Geochemistry, Geophysics, Geosystems 7, 008006.

Wilson, A. H. \& Chaumba, J. B. (1997). Closed system fractionation in a large magma chamber: mineral compositions of the websterite layer and lower mafic succession of the Great Dyke, Zimbabwe. Mineralogical Magazine 61, 153-173.

Yang, S. H., Hanski, E., Li, C., Maier, W. D., Huhma, H., Mokrushin, A. V., Latypov, R., Lahaye, Y., O’Brien, H. \& Qu, W. J. (2016). Mantle source of the $2 \cdot 44-2.50 \mathrm{Ga}$ mantle plume-related magmatism in the Fennoscandian Shield: evidence from $\mathrm{Os}, \mathrm{Nd}$ and $\mathrm{Sr}$ isotope compositions of the Monchepluton and Kemi intrusions. Mineralium Deposita doi:10.1007/s00126-016-0673-9. 